\title{
PETROLOGICAL AND STRUCTURAL ANALYSIS OF THE HAUKIVESI AREA BETWEEN VARKAUS AND SAVONLINNA, FINLAND
}

\author{
G. GAÁL and E. RAUHAMÄKI
}

G. GaÁl and E. Rauhamäkr 1971: Petrological and structural analysis of the Haukivesi area between Varkaus and Savonlinna, Finland. Bull. Geol. Soc. Finland 43, 265-337.

The Haukivesi area is part of a Precambrian orogenic belt. Its supracrustal rocks can be regarded as having been deposited in a geosynclinal system consisting of an eugeosynclinal basin in the northern and central Haukivesi area and a miogeosynclinal trough recognizable in the southern Haukivesi area. The eugeosynclinal facies is represented by a monotonous series of veined gneisses and a complex of diopside-amphibolites, the latter being mainly of volcanic origin. The rocks of the miogeosynclinal facies deposited under synorogenic conditions, comparable to the flysch of the Alpine orogeny, at the same time as the folding of the eugeosynclinal series started in the north. They are composed of metaturbidites with conglomerate intercalations at the bottom. Due to strong metamorphism, the bulk of the turbidites has been converted into coarse grained cordierite gneisses. A geanticline probably existed between the eugeosynclinal and the miogeosynclinal basins where the old basement might have been exposed, as is indicated by granite and granodiorite pebbles in the conglomerate.

The supracrustal rocks are intruded by a manyfold series of plutonic rocks accompanied by various types of migmatites. The structures and compositions of the migmatites were studied in detail because they play an important role in the classification of the intrusive rocks. Typical of the Haukivesi area are trondhjemites and a mangeritic intrusion series ranging in composition from quartz-diorite to ultrabasics. The mangeritic intrusions are connected with palingenetic trondhjemite migmatites, among which the most characteristic for the Haukivesi area are intrusive breccias and schollenmigmatites. The term charnockite has been applied to some mangeritic rock and also to some veined gneisses. These charnockites represent a zone of extremely high PT-conditions and they seem to be associated with the Ni-Cu-bearing basic and ultrabasic intrusives encountered in the Haukivesi area.

The rocktypes of the Haukivesi area are highly metamorphosed under the PT-conditions of the almandine-amphibolite facies and, along the central axis of the Haukivesi in a NW-striking zone, the granulite facies. Their tectonics are characterized by complicated deformation patterns produced by multiphase folding, intrusions and fracturing. The earliest structures are probably the south-facing recumbent folds and overthrusts connected with early tectonic trondhjemite intrusion sheets. During the second or main deformation phase the greatest normal stress $\left(\sigma_{1}\right)$ acted in N-S direction as a strong compression and the least normal stress $\left(\sigma_{3}\right)$ in $\mathrm{E}-\mathrm{W}$ direction as a moderate compression. 
This stress field generated E-W-striking isoclinal folds in en echelon manner which were immediately affected and rotated towards NW-SE by a strong shear stress $\tau= \pm \frac{\sigma_{1}-\sigma_{3}}{2}$ The shear relaxed partly in the formation of vertical right hand folds and partly by right hand faults in N $42 \mathrm{~W}$ direction. These tectonic events were accompanied by the syntectonic intrusion of the bulk of the mangeritic rocks. In the third deformation phase the orientation of the stress field remained but its intensity changed. $\sigma_{1}$ acted in E-W, $\sigma_{3}$ in N-S direction. The stress field produced N-S striking open folds which were superimposed on the older structures as culminations and depressions, leading to the formation of domes and brachyantiforms. At the same time a new shear zone developed in N $53 \mathrm{~W}$ direction with a system of left hand transcurrent faults which were partly superimposed on the older right hand faults.

The absolute age of the mangeritic-intrusions, resulted from two isotopically dated zirkons, is around 1925 m.y.

\author{
G. Gaál, Exploration Department, Outokumpu Co, P.O.Box 27, 02101 Tapiola, \\ Finland.
}

E. Raubamäki, Outokumpu Co, 83500 Outokumpu, Finland.

\title{
CONTENT
}

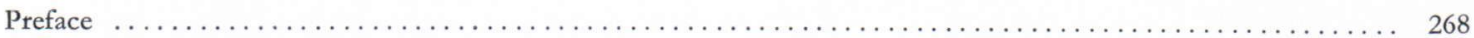

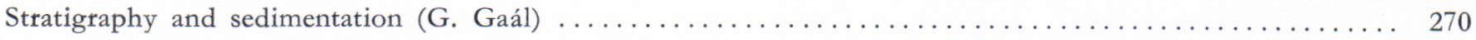

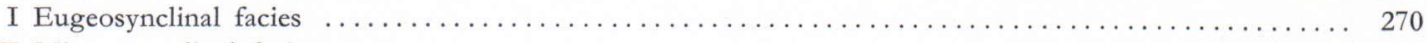

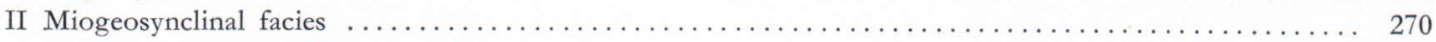

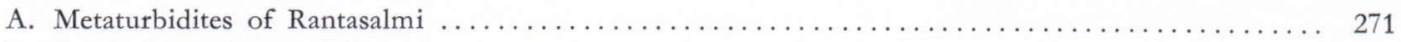

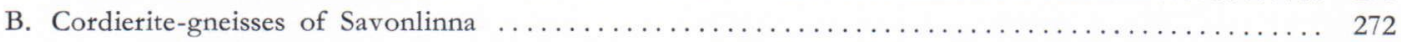

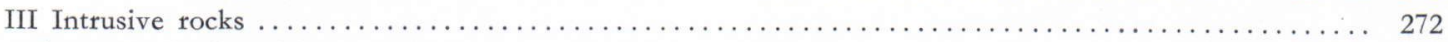

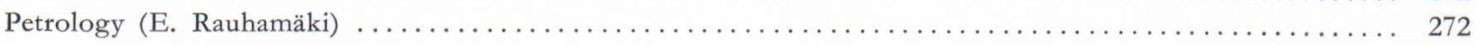

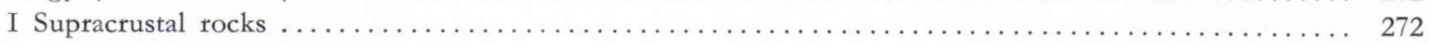

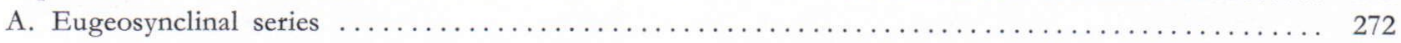

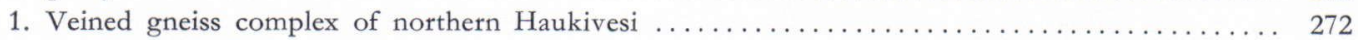

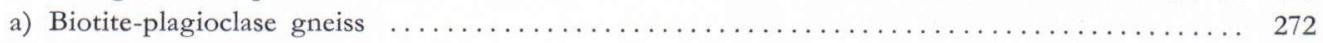

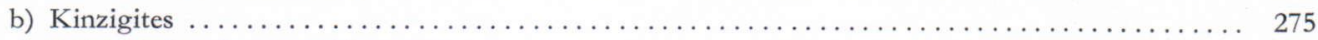

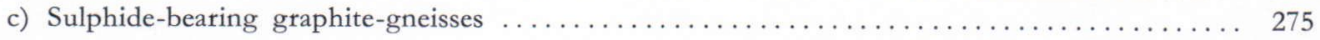

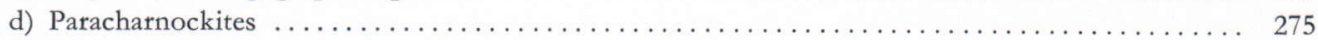

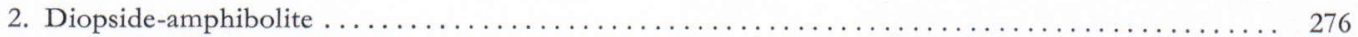

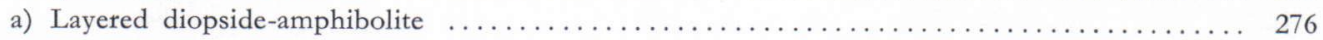

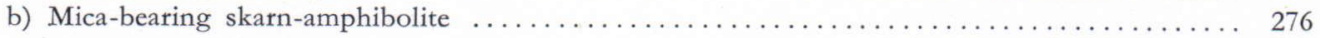

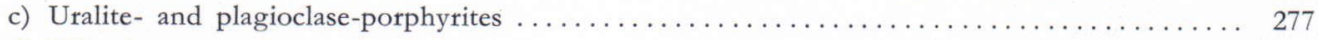

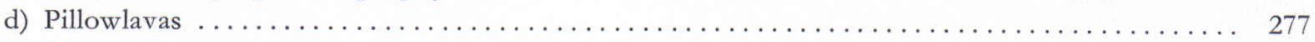

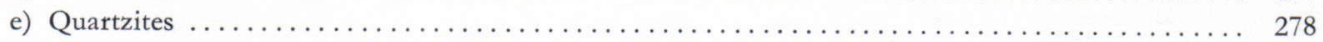

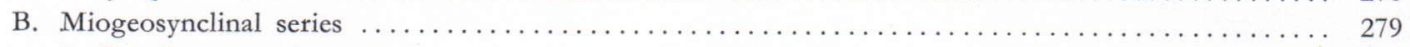

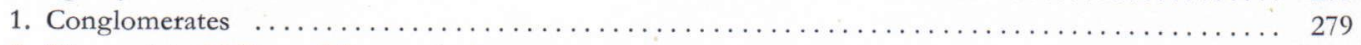

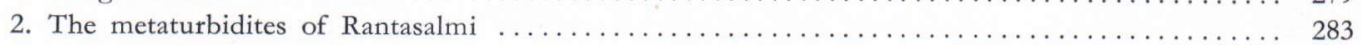

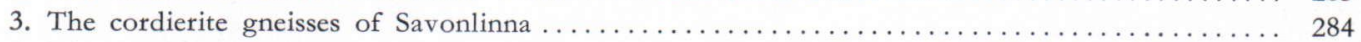

4. The amphibole- and pyroxene schists connected with the cordierite gneiss $\ldots \ldots \ldots \ldots \ldots$

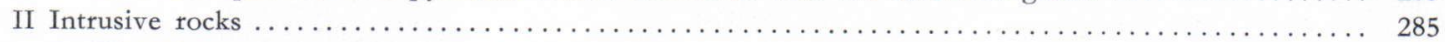

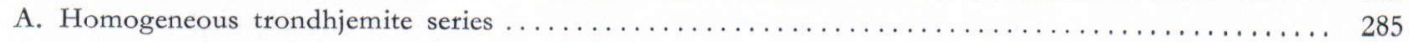




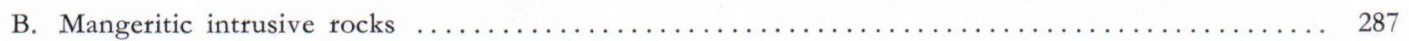

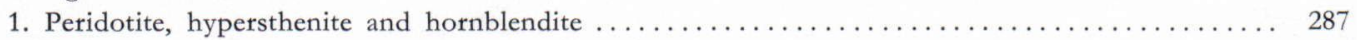

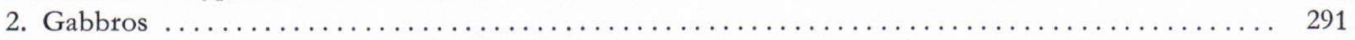

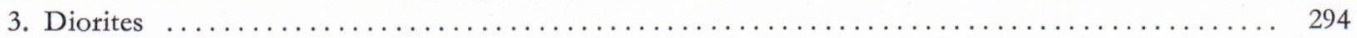

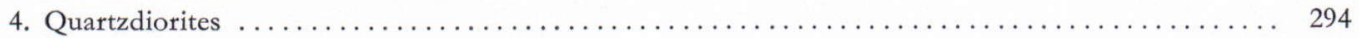

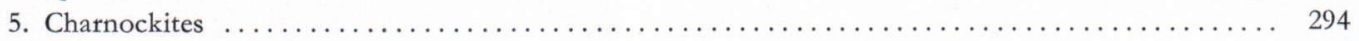

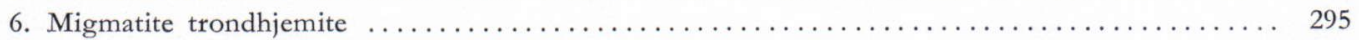

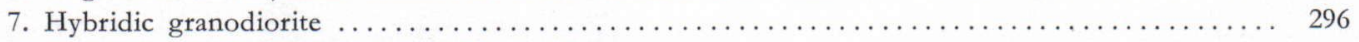

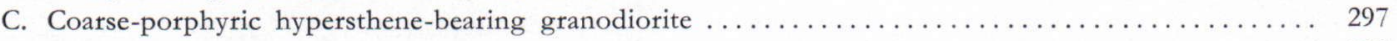

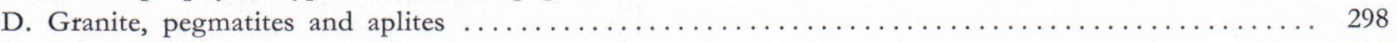

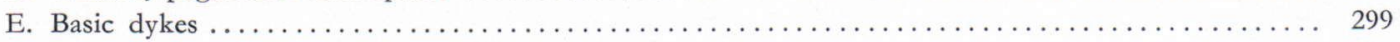

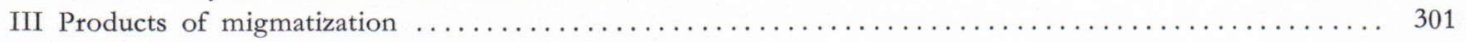

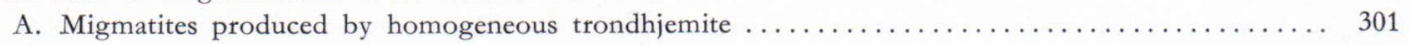

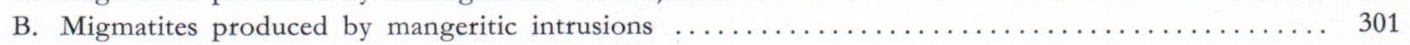

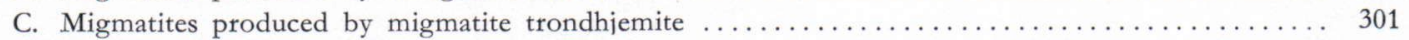

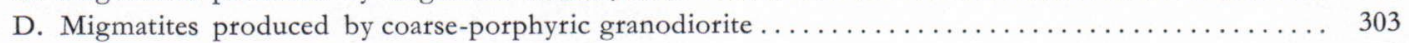

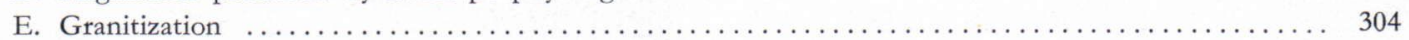

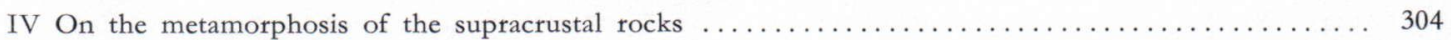

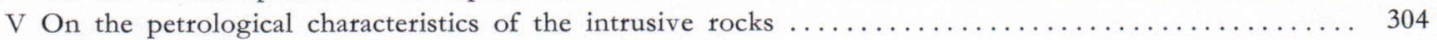

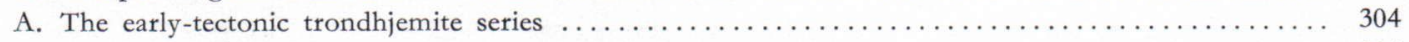

B. The mangeritic intrusives and the coarse-porphyric granodiorite as magmatic charnockites ...... 304

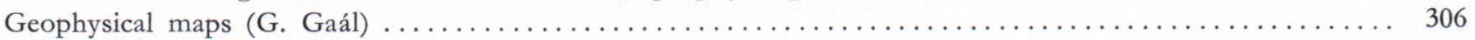

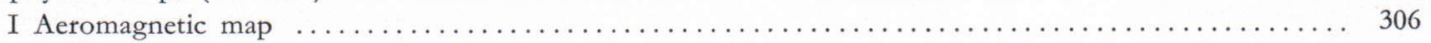

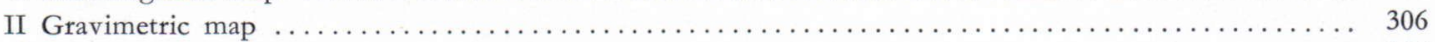

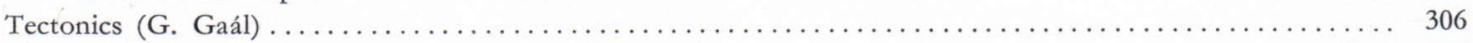

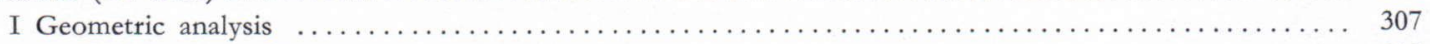

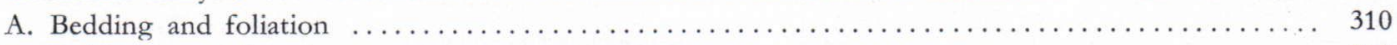

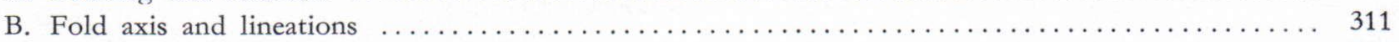

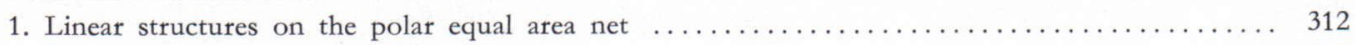

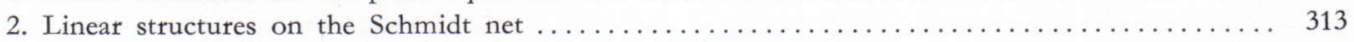

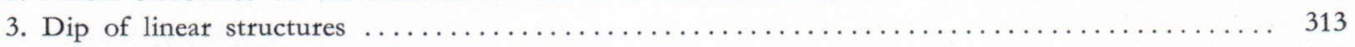

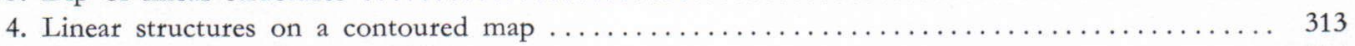

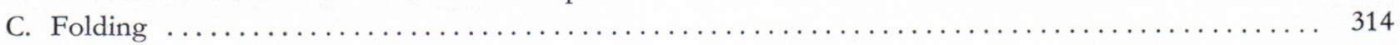

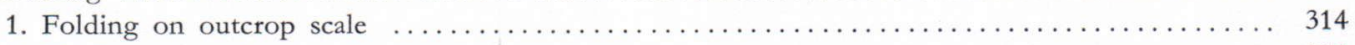

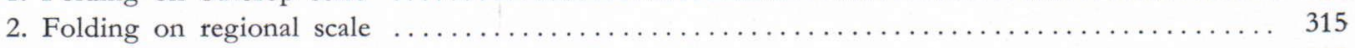

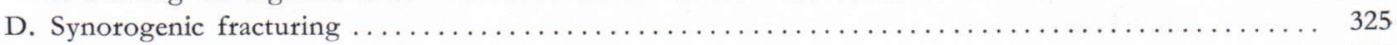

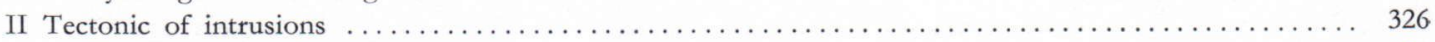

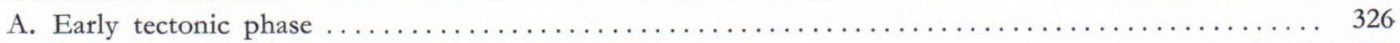

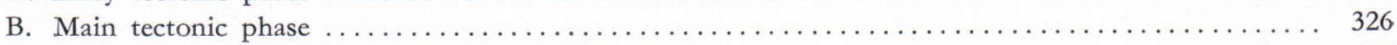

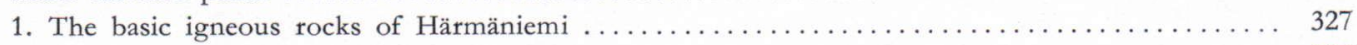

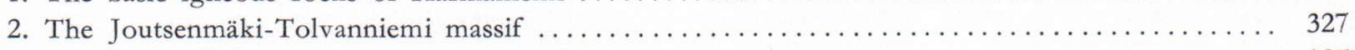

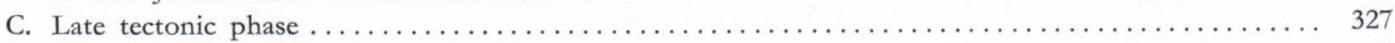

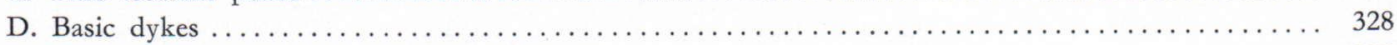

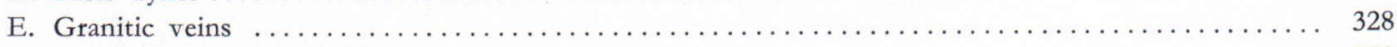

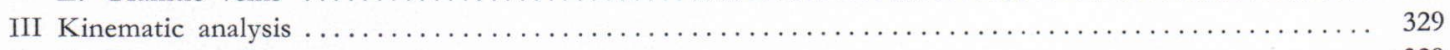

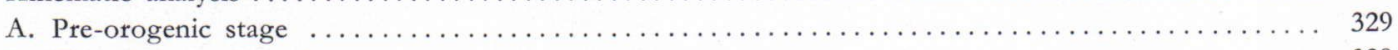

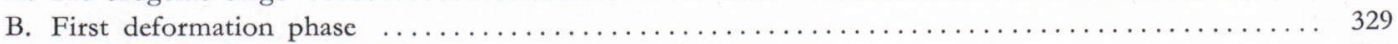

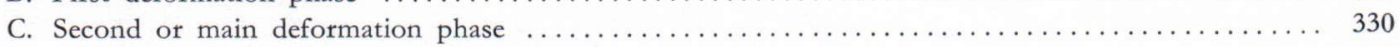

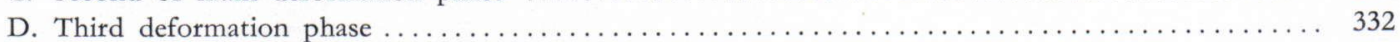

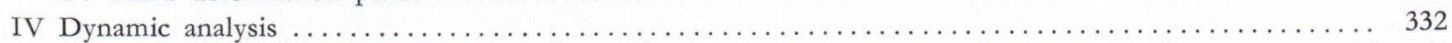

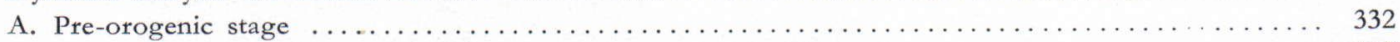

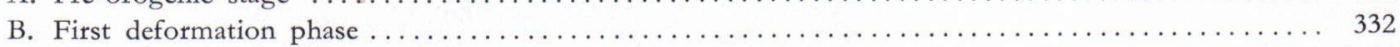

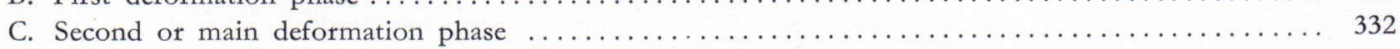

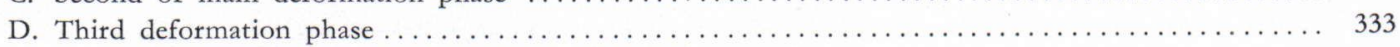




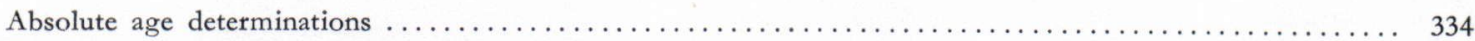

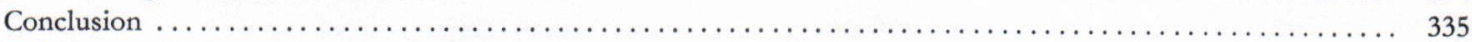

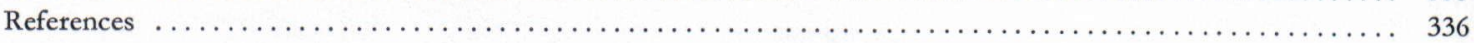

\section{PREFACE}

In many works on Precambrian geology petrological and mineralogical aspects are overemphasized, which in some cases leads to a onesided interpretation of the geologic observations. However, the geology of a strongly deformed and metamorphic terrain cannot be explained by the petrology of its rock types alone, nor can a map based purely on petrographic observations provide a complete geological picture. This is especially clear in the rather complicated geological features of the Haukivesi area, where special attention was paid to tectonics and stratigraphy.

In the tectonic studies of the present work methods were applied which have been developed in younger, three-dimensionally exposed terrains, especially in the Alps and Scottish Highlands. However, theories valid in younger mountain chains cannot be applied in this area without reservations. Right at the initial stages of the work we were compelled to recognize that data collected with these methods must be interpreted with great caution. In order to achieve an objective picture, statistical methods were applied. Co-workers collected large quantities of data which were processed statistic-graphically in various diagrams and maps. In the text the main tendency is to separate empirical data from hypothetical conclusions.

The petrological part of this study is basically a petrographic description of the rock types. However, it was possible to make some important petrological conclusions which may provide the initiative for further petrological research in the area.

The Exploration Department of the Outokumpu Co. has been carrying out systematic geologic research in the Haukivesi area since 1963. The initial impetus to this operation was given by $\mathrm{Ni}-\mathrm{Cu}$-bearing boulders of basic and ultrabasic plutonic rocks found in many places in the northern and central Haukivesi area. Accordingly at the beginning, the geological mapping was concentrated on basic and ultrabasic plutonic rocks. Nevertheless, it was soon realized that the geology of the area could not be understood without a detailed knowledge of its supracrustal formations, and systematic geological mapping covering the whole Haukivesi region between the towns of Varkaus and Savonlinna was started on the scale 1:20000. At a later stage the detailed geological mapping of some key areas was found to be necessary and, at present, geological research is continuing in smaller areas favourable for the occurrence of ores.

The main phase of the field work was carried out under the guidance of E. Viluksela between 1963 and 1967 who directed a team consisting of four field groups lead by G. Gaál, T. Karppanen, J. Parkkinen and E. Rauhamäki. Some smaller areas were mapped by R. Hämäläinen and U. Zischinsky (Fig. 1). Following the field work, the data were compiled by G. Gaál, J. Parkkinen and E. Rauhamäki.

The second phase of the field work, revisions and detail mappings on the scales 1:10000, $1: 4000$ and $1: 2000$, was carried out under the supervision of $\mathrm{G}$. Gaál by field groups lead by G. Gaál, L. Grundström, E. Mattila and O. Rosenlund in 1969 and 1970 (Fig. 1).

The present publication is the result of cooperation by G. Gaál and E. Rauhamäki. G. Gaál, the senior author, is responsible for the stratigraphic and tectonic part as well as for compiling the enclosed maps and making the detail drawings. The petrographic part of the work was carried out mainly by E. Rauhamäki. The photo- 


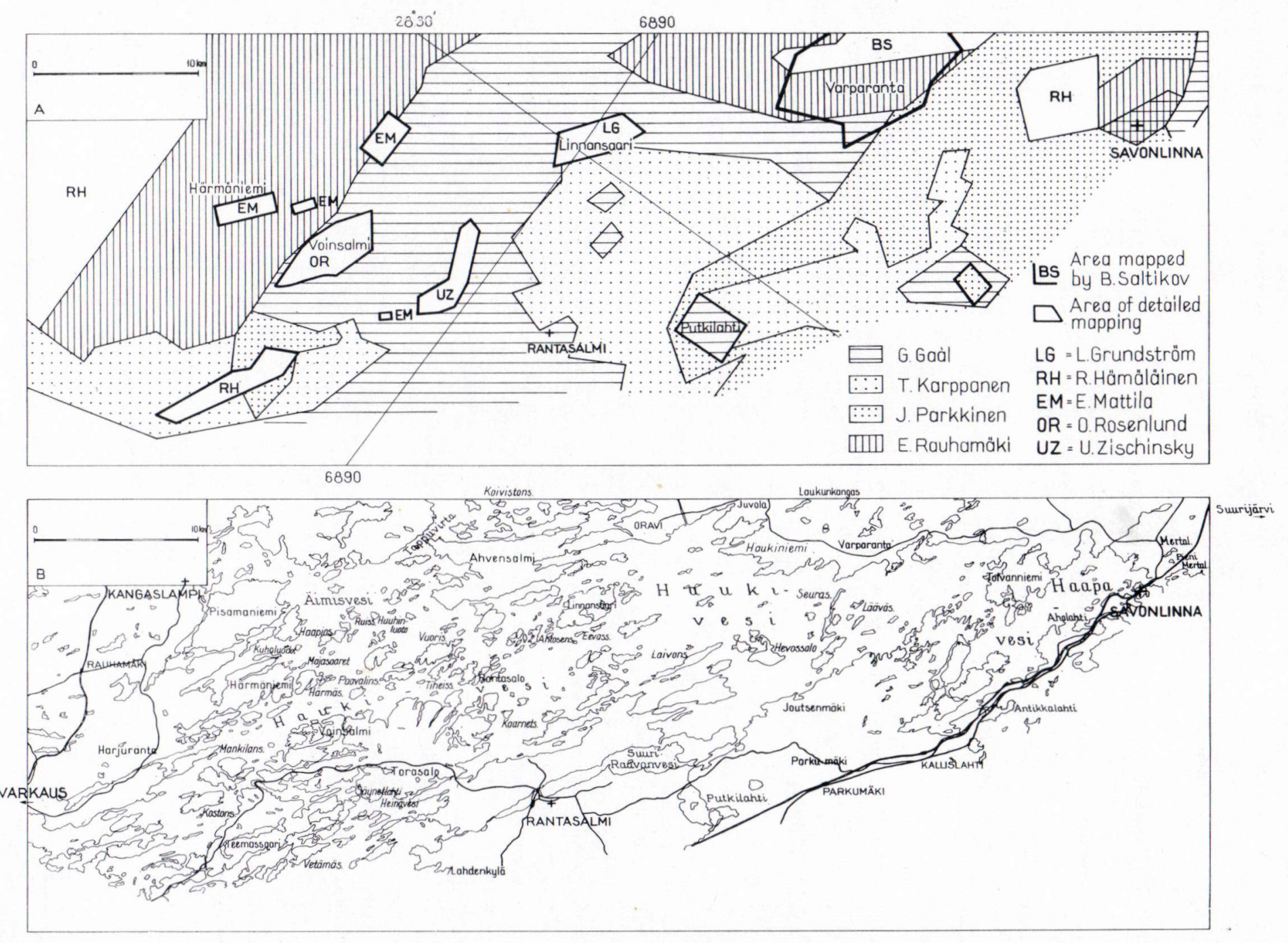


graphs in the text were taken by G. Gaál, T. Karppanen, J. Parkkinen, E. Rauhamäki and E. Viluksela. Furthermore, the information provided by the M. Sc. thesis of B. Saltikoff (1965) on the Varparanta area was incorporated in the present study (Fig. 1).

Since 1967 A. Häkli has studied the silicate nickel contents of the basic and ultrabasic plutonic rocks of the Haukivesi area. A vast amount of material was collected which proved to be useful in the ore prospecting and also provided information of general geological interest.

\section{STRATIGRAPHY AND SEDIMENTATION}

\section{G. Gaál}

As a result of this analytical study, some typical features of an orogenic belt were identified in the petrology and deformation patterns of the Haukivesi area. Sedimentation, igneous activity and deformation phases can therefore be incorporated into a far greater series of geological processes, the Precambrian orogeny, which comprises the bulk of the Finnish Precambrian.

According to the environment of deposition, the supracrustal rocks of the area in question can be divided into two groups: those of the eugeosynclinal and those of the miogeosynclinal facies. There is an age difference between these two groups. The unmetamorphosed equivalents of the veined gneiss complex and the diopsideamphibolite series were the first to deposit in a great eugeosynclinal basin. In and after the closing stage of the eugeosynclinal sedimentation, the unmetamorphosed equivalents of the Rantasalmi metaturbidites and the Savonlinna cordierite-gneisses deposited in a newly formed and rapidly subsiding miogeosynclinal trough south of the eugeosynclinal belt. Sedimentation in the miogeosynclinal stage was mainly psammitic. There was a geanticline between the eugeosynclinal and the miogeosynclinal zone where the old basement might be near to the present surface. It is possible that the basement is exposed in the Haukivesi area but it was impossible in the course of this study to prove its existence among the various types of intrusive rocks and migmatites.

\section{EUGEOSYNCLINAL FACIES}

The greatest part of the eugeosynclinal group consists of metamorphosed and migmatized pelitic to psammitic rocks, the so-called v e in ed $\mathrm{g} n \mathrm{e}$ is s e s. The primary material of the veined gneisses deposited in a relatively quiet environment. The primary structures, bedding, lamination and thin, persistent calc-silicate intercalations, indicate a monotonous series of geosyncline sediments which deposited during slow and continuous subsidence.

The veined gneiss complex is thickest in the northern part of the area. Southwards, with the emergence of the diopside amphibolite, it is considerably reduced due to the influence of a geanticline. The fairly thich sequence of diopside-amphibolite is stratigraphically on the top of the veined gneisses. Its primary material is of volcanic origin which can be compared with the ophiolites of younger mountain chains. The pillow-lavas of the Parkumäki-Varparanta zone represent primary basaltic material which had extruded on the bed of the sea. The largest part of the diopside-amphibolite is sedimentary reworked volcanic material, which, together with the marble and quartzite intercalations, had deposited in fairly shallow sea water. Tuffs also supplied a part of the basic material.

\section{MIOGEOSYNCLINAL FACIES}

At the closing stage of the eugeosynclinal period, conditions changed rapidly. The geanticline rose above sea-level and rapid erosion started along its ridge. The most obvious product of erosion was the formation of conglomerates. These contain pebbles of fresh basic volcanics, leptite fragments, mica-gnesss pebbles from the eugeosynclinal stage and granite pebbles. The latter indicate that the old basement 


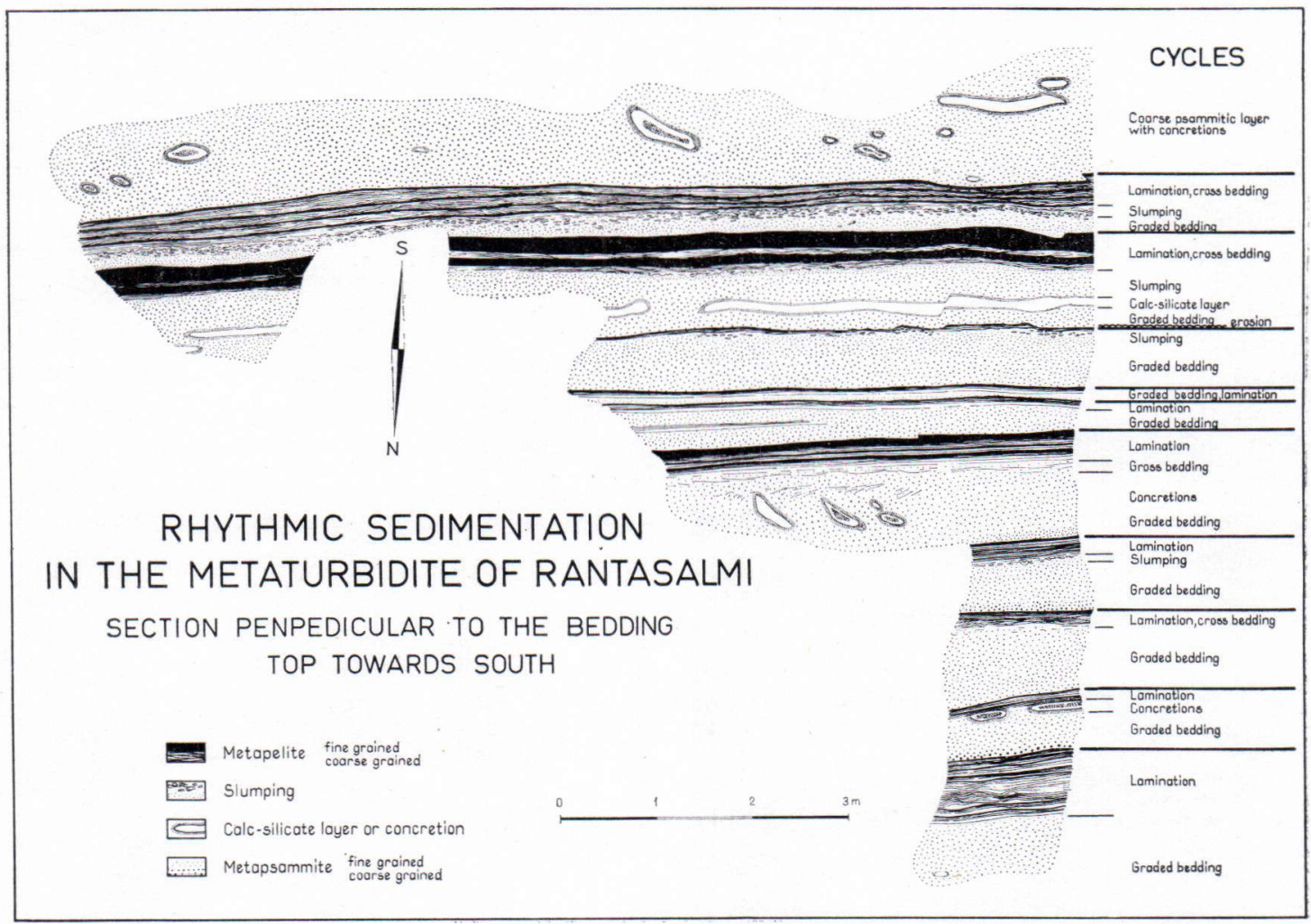

FIG. 2.

must have been exposed in some places in a geanticline near Savonlinna. The basement was apparently of granitic to granodioritic composition.

Rapid subsidence started south of the geanticline and the miogeosyncline was formed. Sedimentation began with coarse psephitic material near the geanticline above a minor unconformity, and continued with psammitic material of flyschcharacter. The source of sedimentation must have been in the north, where the folding and elevation of the eugeosynclinal zone started during the formation of the miogeosynclinal through.

\section{A. Metaturbidites of Rantasalmi}

Typical features of turbidites were recognized in the well-preserved sedimentary structures of the metagraywackes of Rantasalmi. The bestpreserved metaturbidite-exposure WNW of Rantasalmi is illustrated by a detail drawing (Fig. 2). In the rhythmic arrangement of pelitic and psammitic layers cycles can be distinguished in which similar sedimentary structures and material are repeated. A complete cycle contains a typical sequence of sedimentary material and structures. (Fig. 3.).

The coarse-grained psammitic material at the bottom of the cycle changes upwards into fine-grained psammite through graded bedding. The graded-bedded psammitic layer contains layers or concretions of calc-silicate material. The fine-grained upper part of the gradedbedded layer is synsedimentary folded and contains slumping structures $i e$. small rounded and rolled finegrained mud balls with laminated structures. The slumping bed is covered by fine, laminated, pelitic material which may contain alternating layers of very fine-grained and laminated pelite and less fine-grained 


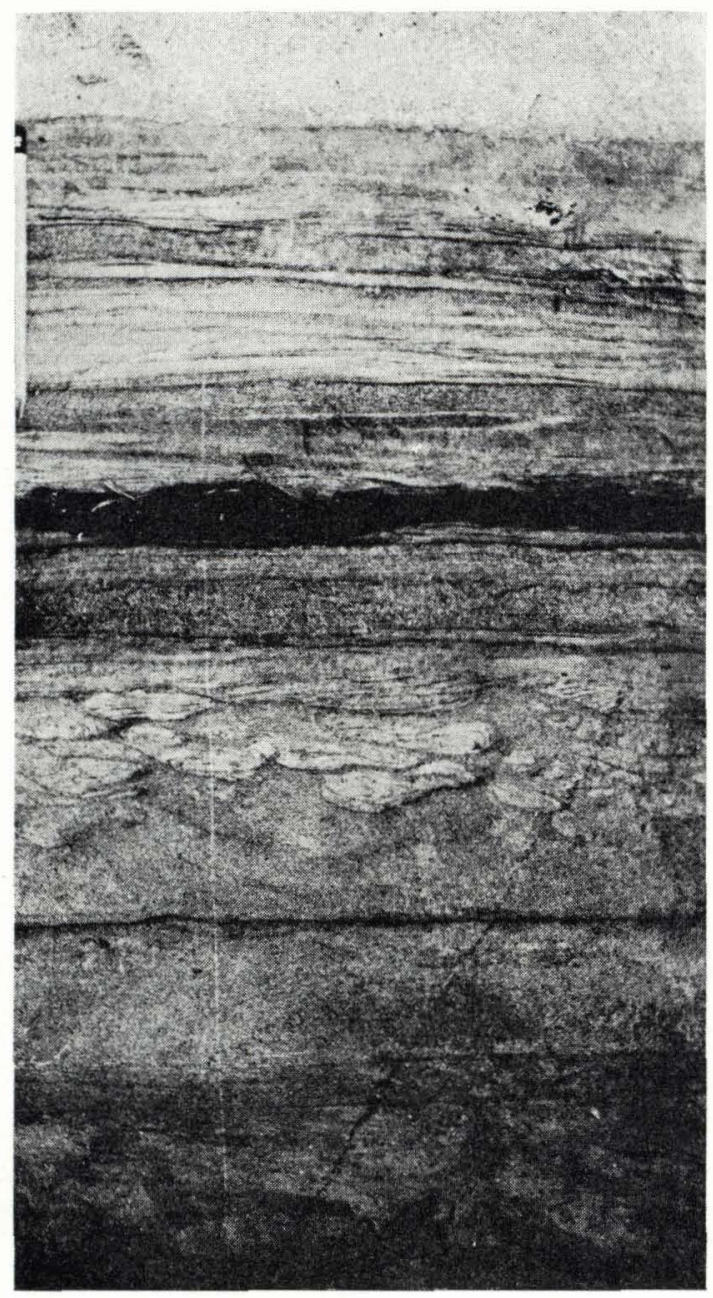

FIG. 3. Slumping structures in the Rantasalmi metaturbidite, Lahdenkylä, Rantasalmi.

pelitic layers, thus exhibiting small-scale cross-bedding. The top of the cycle is a very fine-grained pelite. The average cycle is incomplete, eg. the upper part of the cycle may occasionally be truncated by erosion.

Each cycle in the metaturbidites contains the material brought into the miogeosyncline by a single turbidity current. The mechanism of this process and methods of studying turbidites are described by A. H. Bouma (1962).

\section{B. Cordierite-gneisses of Savonlinna}

In the cordierite gneisses of Savonlinna, the rhythmic alternation of primary pelitic and psam- mitic material, concretions and graded bedding can be recognized. Because of geological evidence, they must be regarded as strongly metamorphosed turbidites, although such subtle structures as cross-bedding and slumping have disappeared in the course of recrystallization.

\section{INTRUSIVE ROCKS}

The history of the intrusive rocks started together with the folding of the miogeosynclinal sediments. It is possible to divide the intrusive rocks into a time succession with the aid of the deformation history and the contact relations. This, however, is dealt with in the petrological sector and structural analysis.

\section{PETROLOGY}

\section{E. Rauhamäki}

\section{SUPRACRUSTAL ROCKS}

(Mineral compositions Table 1 and 2)

\section{A. Eugeosynclinal series}

\section{Veined gneiss complex of northern Hankivesi}

a) Biotite-plagioclase gneiss

Most of the biotite-plagioclase gneisses are garnet-bearing veined gneisses. Only some small parts of a schist formation which have avoided migmatization occur in Kangaslampi and Oravi. A pale trondhjemitic rock acts as the migmatizing vein material. Macroscopically, the biotite plagioclase gneisses are fine- to medium-grained rocks, the weathered surface of which is a dirty brownish grey or pure grey in colour. The brownish colour is caused by the low-grade pyrrhotite and graphite content. This later type is more clearly layered and richer in biotite than the grey type which often forms agmatic migmatites (Fig. 4) and usually contains abundant red garnets composed of almandite-pyrope $(70: 30)$. The indistinct bedding so often apparent in the biotite plagioclase gneisses is due to the various 
TABLE 1.

Mineral compositons of the supracrustal rocks of the Haukivesi area.

1-6 (point counting method)

$7-17$ (Terry \& Chilingar method)

$x$ met in small amounts

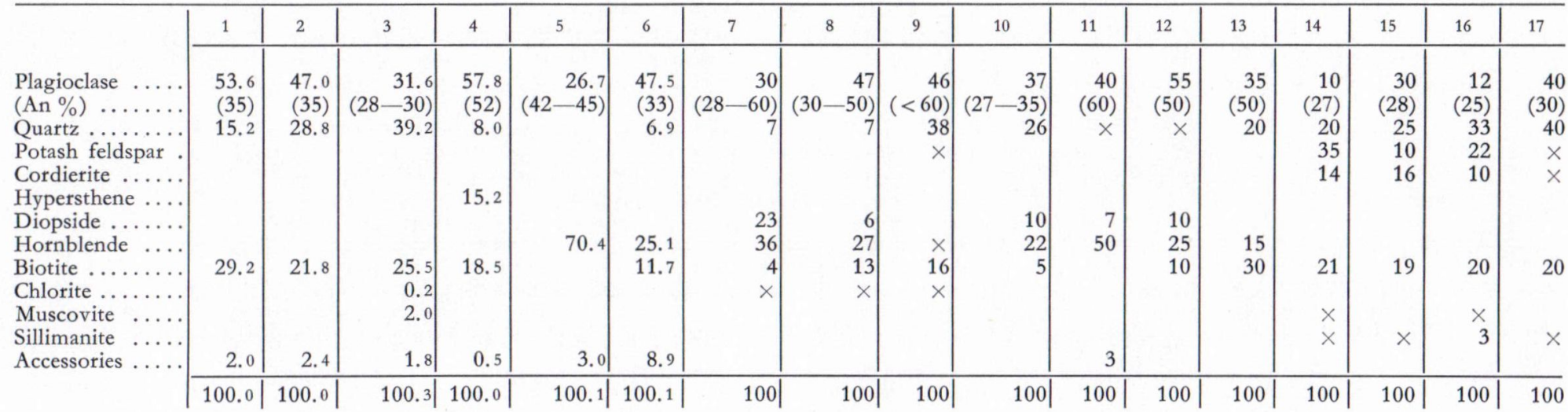

1. Biotite-plagioclase gneiss, Harjuranta

2. Biotite-plagioclase gneiss, Harjuranta

3. Garnet-bearing mica gneiss, Varparanta (B. Saltikoff 1965)

4. Hypersthene gneiss (paracharnockite), Härmäniemi

5. Layered diopside-amphibolite, amphibolitic part, Varparanta (B. Saltikoff 1965)

6. Mica amphibolite, Varparanta (B. Saltikoff 1965)

7. Banded diopside skarn amphibolite, 7 specimens, southern Haukivesi

8. Hornblende-plagioclase gneiss intercalations in amphibolites, 7 specimens, southern Haukivesi

9. Biotite-plagioclase gneiss intercalations in amphibolites, 2 specimens, southern Haukivesi

10. Pillow lava, 4 specimens, Parkumäki

11. Uralite porphyrite, 3 specimens, southern Haukivesi

12. Hornblende-plagioclase gneiss with diopside skarn layers, 3 specimens, Savonlinna

13. Hornblende-plagioclase gneiss, Savonlinna

14. Cordierite gneiss, 3 specimens, Savonlinna

15. Cordierite gneiss, 5 specimens, Kallislahti

16. Cordierite gneiss, 10 specimens, Parkumäki

17. Cordierite gneiss (psammitic layers), 5 specimens, Kallislahti and Parkumäki. 
TABLE 2.

Mineral compositions of the Savonlinna conglomerate

(Terry \& Chilingar method)

$\times$ met in small amounts

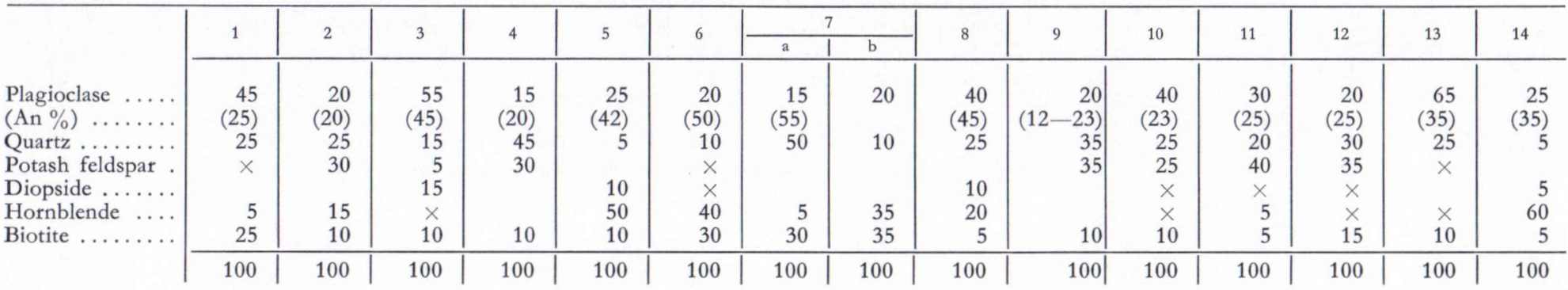

1. Biotite-hornblende gneiss matrix, 4 specimens, Mertalampi

2. Hornblende gneiss matrix, 2 specimens, Mertalampi

3. Mica gneiss matrix with skarn layers, 2 specimens, Mertalampi

4. Graywacke matrix, 2 specimens, Pieni Mertalampi

5. Amphibolite matrix, 3 specimens, Pieni Mertalampi

6. Mica amphibolite matrix, 1 specimen, Pieni Mertalampi

7. Graded bedded hornblende-plagioclase gneiss intercalation, Pieni Mertalampi

a) psammatic part b) pelitic part

8. Hornblende-plagioclase gneiss intercalation with diopside skarn, 2 specimens, Pieni Mertalampi

9. Granite pebbles, 2 specimens, Mertalampi

10. Granite pebbles, 3 specimens, Mertalampi

11. Pebble of porphyric granite, Mertalampi

12. Mica gneiss pebbles, 3 specimens, Mertalampi

13. Biotite-plagioclase gneiss pebbles, 3 specimens, Mertalampi

14. Amphibolite pebble, Mertalampi 


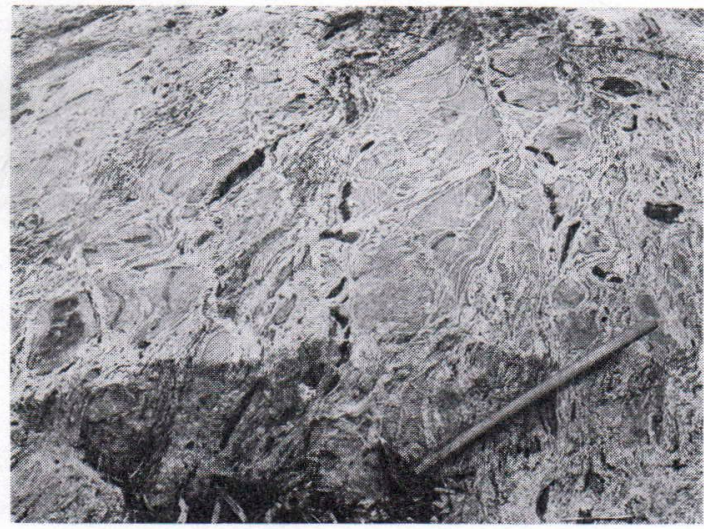

FIG. 4. Agmatite: biotite plagioclase gneiss brecciated by trondhjemite, Kangaslampi, Harjuranta, Mankilansaari.

shades and abundances of mica between the beds. Oval concretions $(5-20 \mathrm{~cm}$ in diameter) are not uncommon.

Plagioclase (An 30-35) is always the most abundant mineral in the rock. In some cases, there is almost as much quartz. The third chief mineral is biotite. The abundance of garnet varies. In the mica-rich types it is an accessory mineral, but in the rocks with a low mica content it occurs parallel to the bedding, has a grain size of $1-20 \mathrm{~mm}$ and accounts for up to $20 \%$ of the minerals. Accessories are apatite, zircon, opaques, potash feldspar (+antiperthite), sericite, chlorite, carbonate and titanite.

There are occasional calc-silicate intercalates in the biotite-plagioclase gneisses, in which diopside and local pale green and weakly pleochroitic hornblende occur as the skarn minerals. The composition of the plagioclase is An 60-65.

Pyrrhotite dissemination is common. Carbonate and idiomorphic titanite are encountered as accesssories.

\section{b) Kinzigites}

Intercalates containing coarse-grained cordierite and garnet are occasionally associated with the biotite-plagioclase gneisses of the OraviTappuvirta and Voinsalmi-Torasalo areas. Cha- racteristic of these layers are the intensive miniature folding, the strong recrystallization compared with the environment and the rusty surface due to the low-grade pyrrhotite dissemination. The major minerals of the kinzigites characterized by cordierite are plagioclase (n 30-50), potash feldspar, biotite, cordierite and quartz. Cordierite and potash feldspar occur as porphyroblasts. The former is usually intensely pinitized whereas the latter is sometimes entirely lacking.

The kinzigites of Voinsalmi-Torasalo are poor in mica, and in addition to cordierite, contain abundant garnet. Common accessories are sillimanite, opaques, apatite, zircon and antiperthite as well as in this case hercynitic spinel.

c) Sulphide-bearing graphite$\mathrm{g} n$ eis se s

In places the biotite-plagioclase gneisses contain such an abundance of graphite that they may be called graphite-gneisses. A fine-grained pyrrhotite dissemination always seems to follow the graphite. The graphite gneisses occur as intercalates varying in thickness from a few metres to several tens of metres which are usually only weakly migmatized. It has often been observed that they cause magnetic and electric anomalies and that they are strongly sheared. Exposures of the sulphide-bearing graphite-gneisses are covered by a rusty weathered layer, which may extend down to a depth of $10-20 \mathrm{~cm}$. The mineral composition corresponds to that of the biotite-plagioclase gneisses as far as the silicates are concerned even though the plagioclase is richer in calcium (An 35-45) and diopside may be present. Garnet seems to be lacking. Apatite and zircon are encountered as accessories. It is typical of graphite that it occurs as intergrown sheets together with biotite. The rocks are nematoblastic in structure.

d) Paracharnockites

In the following, paracharnockites (K. Parras 1958) are understood as hypersthene-cumming- 
nite-rich biotite-plagioclase-gneiss variants. They occur in the southern part of the veined gneiss complex in the Harjuranta-Härmäniemi and Kostonsaari-Voinsalmi-Torasalo areas in zones which contain abundant hypersthene-rich intrusive rocks. On the geological map they cannot be distinguished from veined gneisses because identification is not possible in the field without microscopical studies.

The following rocks can be distinguished on the basis of their mineral composition: hypersthene-gneisses, hypersthene-cummingtonite-gneisses and cummingtonite- or hypersthene-bearing biotite-plagioclase gneisses, all of which grade into one another. Hypersthene is usually unaltered, although alternations into cummingtonite have been observed.

The most common type of paracharnockite is a fine-grained, oriented hypersthene gneiss with plagioclase (An 40-45), quartz, biotite and hypersthene as major minerals. Accessories are apatite, opaques, garnet and rare hornblende. The microscopic structure corresponds to that of the biotite-plagioclase gneiss.

An exceptionally fine-grained $(0.1-0.3 \mathrm{~mm})$ banded hypersthene gneiss was encountered in Härmäniemi. According to field observations, it is a xenolith in a hyperthene-diorite with a diameter of several tens of metres. Petrographically, it is relatively poor in quartz but rich in garnet and structurally granoblastic like a hornfels.

\section{Diopside-amphibolite}

The chief zone of the diopside-amphibolites runs through the whole Haukivesi area as a coherent layer which varies in thickness and is strongly folded. On the geological map this zone forms a kind of backbone separating the northeastern veined gneiss complex from the southwestern metaturbidite complex. Another isolated diopside-amphibolite zone occurs in the Savonlinna cordierite-gneiss together with a conglomerate formation. The most common type of amphibolite is distinctly bedded and schistose, dark-green in colour and with light green diopside-skarn intercalates. In the Savonlinna area, mica amphibolites with skarn bands are mainly encountered. In addition, uralite-plagioclase porphyrites, pillowlavas and almost massive amphibolites with an indistinct volcanic structure are met with. Random occurrences of thin quartzitic intercalates have been observed in the amphibolites.

a) Layered diopside-amphibolite

The chief minerals of the competent amphibolite layers in the bedded diopside amphibolite are plagioclase (An 40-65), hornblende and diopside. Accessories are carbonate, titanite, biotite, apatite, pyrrhotite and sometimes chalcopyrite and pyrite. The presence of pyrrhotite seems to be typical, particularly in the skarn intercalates. As a low-grade dissemination, it explains the distinct magnetic and electric anomalies caused by the diopside-amphibolites. In some places, red garnet with a composition of almandite-pyrope $(63: 35)$ is found in the hornblende-rich layers. Diopside is more abundant than hornblende in the skarn layers and occurs as coarser-grained bands together with plagioclase. Blue-green hornblende is encountered as main alternation product of diopside.

The thickness of the calc-silicate and carbonate intercalates (according to $\mathrm{x}$-ray determinations calcite) in the bedded diopside-amphibolites varies from a few $\mathrm{cms}$ to one metre and is occasionally even thicker. The carbon-rich layers are eroded for $5-10 \mathrm{cms}$ on the weathered surface so that they can easily be distinguished (Fig. 5). Pure white calcite layers are not uncommon, although usually the carbonate-rich layers are dark as a result of their hornblende content. Intercalates of pure pale diopside rock in amphibolites have been encountered in Harjuranta in the northern Haukivesi area.

b) Mica-bearing skarn-amphibolite

The banded mica-bearing skarn-amphibolites 


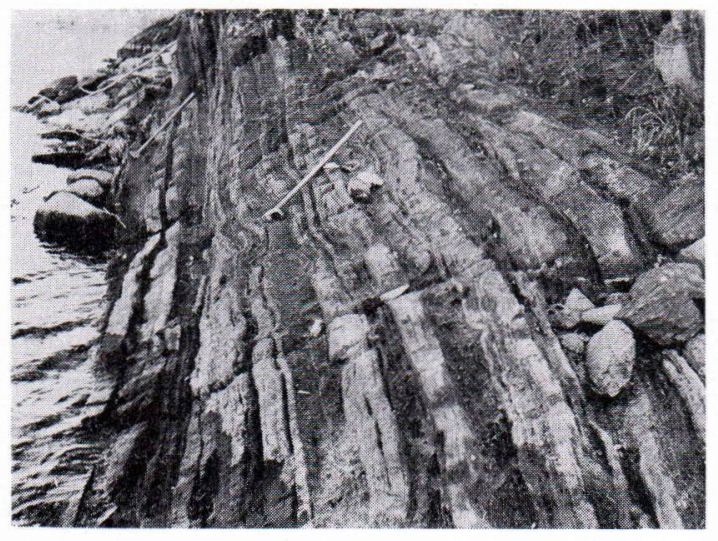

FIG. 5. Layered diopside amphibolite with diopside skarn and carbonate interclations, Kangaslampi, Härmäniemi, Majasaaret.

of the Savonlinna area are more schist-like than amphibolites elsewhere. In some places, there is so much biotite that the rock can be called biotite-hornblende schist. Characteristic of the amphibolite formation are the relatively thin and frequently occurring intercalates of greenish grey diopside skarn as well as the diopside skarn and carbonate lenses and veins varying from 2 $20 \mathrm{~cm}$ in thickness. In some places, layers of almost pure carbonate have been encountered as well. Occasionally, layers of fine bedded biotite-hornblende gneiss occur within the amphibolite with the thickness of the layers varying from $1-5 \mathrm{cms}$. Its plagioclase has a composition similar to that of an amphibolitic plagioclase (An 50-55). The latter rock resembles the banded matrix which occurs locally in the Savonlinna conglomerate. In addition, quartzbearing amphibolite variants are encountered. In the eastern part of the Savonlinna amphibolites and in Kallislahti arkositic intercalates a few metres thick have been met with in the amphibolite near the contacts with cordierite gneiss.

c) Uralite- and plagioclase-porphyrites

Uralite- and plagioclase-porphyrites occur as concordant beds in the amphibolites in Torasalo, Juvola, Varparanta and other places. The matrix of the uralite porphyrite is medium-grained, slightly foliated and poor in diopside. The porphyritic uralite grains vary from $2-20 \mathrm{~mm}$ in size. They are porphyroblasts rather than pyroxene pseudomorphs of volcanic rocks (pyroxene phenocrysts), because they contain other minerals of the rock as inclusions.

The mineral composition of the plagioclase porphyrites corresponds to that of the mica amphibolites. Andesitic plagioclase forms zoned phenocrysts which are sericitized or saussuritized in their central parts $(\varnothing 0.5-2.0 \mathrm{~mm})$ and which are probably phenocrysts (B. Saltikoff 1965). The granoblastic groundmass consists of plagioclase, hornblende and biotite. Accessories are opaques, apatite, sericite, zircon, chlorite and titanite. It is possible that the plagioclase porphyrites were originally andesitic volcanites.

\section{d) Pillow $1 \mathrm{avas}$}

Pillow lava structures were found in the Haukivesi area at first by B. Saltikoff in the amphibolites of Varparanta (B. Saltikoff 1965). In the course of the present investigation, new pillowlavas were discovered in Parkumäki and a supplementary investigation, carried out in 1970, brought to light new pillowlava occurrences at Makkola in the E continuation of the Varparanta amphibolite (T. Karppanen, personal communication). Makkola is located outside the area of the geological map of Haukivesi. Thus, in the southern part of the Haukivesi area there is a distinct and coherent E-W oriented volcanic zone which is at least $25 \mathrm{kms}$ long from Parkumäki to Makkola.

There are dissimilarities between the pillows and the groundmass in the Parkumäki pillowlavas (Fig. 6). The rock in the pillows is diopsidebanded hornblende-plagioclase gneiss which has plagioclase, quartz, hornblende and diopside as major minerals. Biotite occurs partly as a major mineral and partly as an accessory. The grain size varies from very fine-grained to fine-grained. The mineral composition is such that bands containing abundant diopside, biotite and quartz 


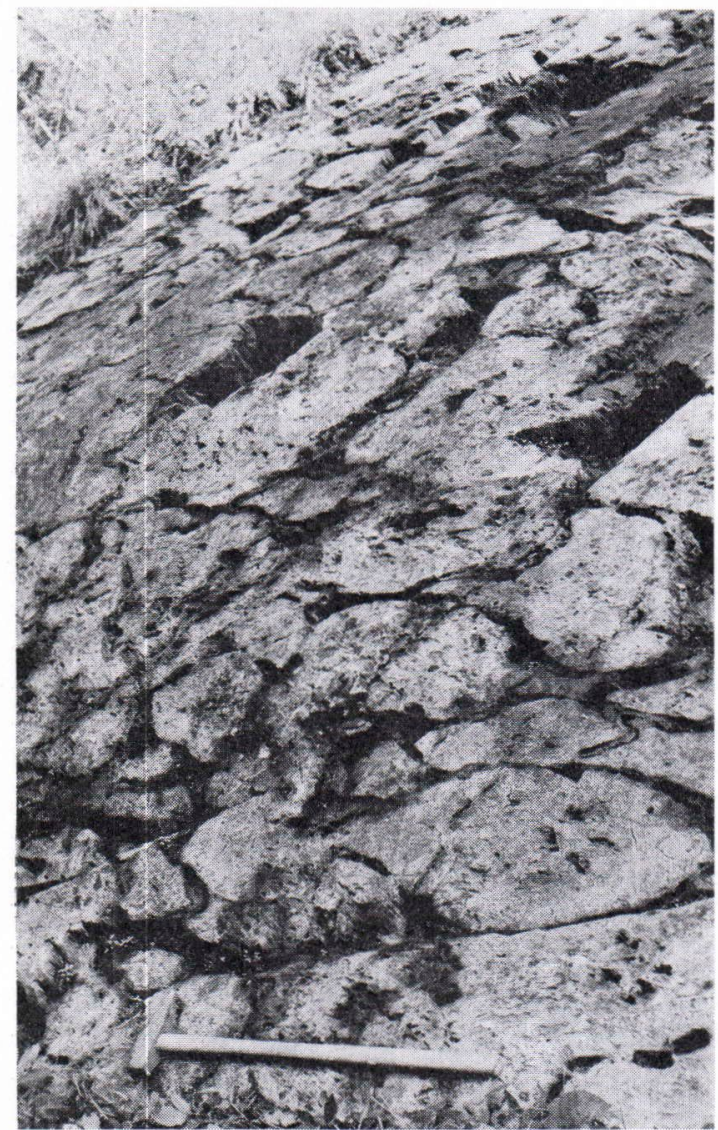

FIG. 6. Pillow lava, Parkumäki.

can all be distinquished from each other. The rock is partly reminiscent of uralite porphyrite with its large hornblende and hornblende-diopside grains. In places the plagioclase is strongly sericitized. The groundmass between the pillows is chiefly composed of hornblende and chlorite both of which have a fan-like orientation.

In association with the bedded diopside amphibolites in both the central and northern Haukivesi areas there are almost massive amphibolite variants with an indistinct volcanic structure. Occasionally they are garnet-hypersthene-cummingtonite-bearing variants and occasionally resêmble biotite-hornblende gneisses. Bedding is generally lacking but irregular carbonate and diopside-rich bands, stripes and lenses can be observed (Fig. 7) which are subparallel oriented. As a whole, the rock is strongly stretched and lineated. It is possible that these diopsideamphibolite variants are strongly deformed pillowlavas. There are also fairly frequently almost massive amphibolite variants which consist of fine-grained diopside-poor hornblende amphibolites. They grade into banded amphibolites through the mediation of striped and banded variants.

\section{e) Quartzites}

In the central Haukivesi area (Karnetsaari, Eevasaari) and along the southern edge of the Torasalo area, thin $(1-30 \mathrm{~cm}$ thick) quartzite and arkosite intercalates have been encountered in a few exposures of the diopside amphibolite formation (Fig. 8). They are so thin that they

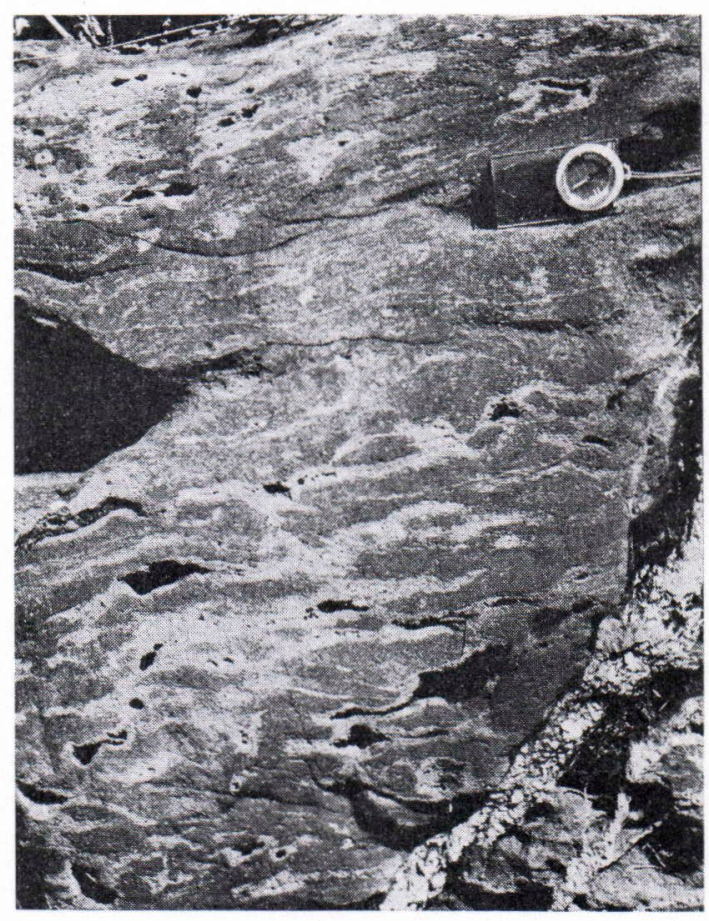

FIG. 7. Amphibolite with tectonized volcanic structures. The pale stripes and lenses are composed of diopside skarn, the cavities are weathered out carbonate fillings, Kangaslampi, Härmäniemi, Kuhaluodot. 


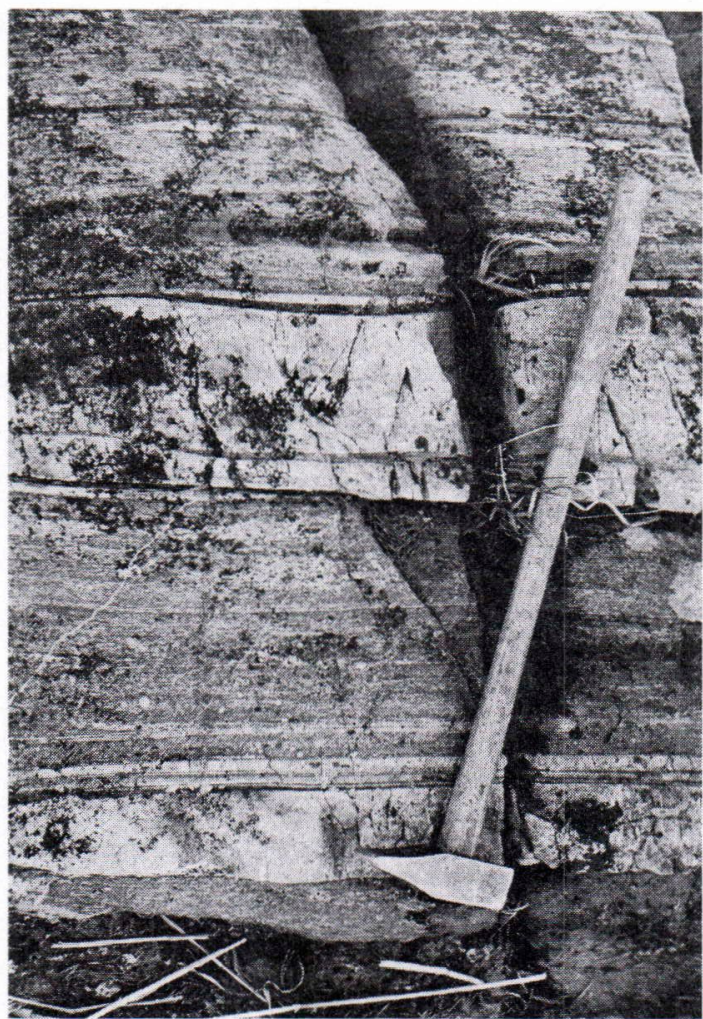

FIG. 8. Quartzite intercalations in amphibolite, Säynetlahti, Rantasalmi.

have not been marked on the geological map. The accessory minerals are green-blue hornblende, carbonate and opaque.

\section{B. Miogeosynclinal series}

\section{Conglomerates}

Although the conglomerate occurrence in the town of Savonlinna had been known to some geologists previously, there is no mention of conglomerates in the Haukivesi area in earlier publications. In this investigation special attention was given to this rock type, which forms an important stratigraphic horizon. Most occurrences of conglomerate in the Haukivesi area were found in connection with the present study.

The conglomerate in the Haukivesi area (Fig. 9) is not a coherent layer but is composed of several separate occurrences, all of which, however, belong to the same stratigraphic horizon, which is located partly between the amphibolite and cordierite gneiss in the Savonlinna area and partly within the cordierite gneiss in the Kallislahti and Parkumäki area. These conglomerates are encountered as 5-200 m thick layers and lens-like formations between Lake Suurijärvi (SE of Savonlinna) and the village of Parkumäki. The distance between the furthest observation points is about $35 \mathrm{~km}$. In addition, a conglomerate boulder was encountered at the southern end of the island of Laivonsaari ( $\mathrm{x}=$ 6882.1 $\mathrm{y}=424.1$ ) in the central Haukivesi area, which indicates that the conglomerate probably extends NW to the northern side of the Rantasalmi metaturbidites between the amphibolite and the metaturbidites. It is unlikely that the conglomerate formation is a local phenomen. I. Salli (1964) for example described very similar conglomerates in a corresponding stratigraphic milieu from the Ylivieska-Himanka area of central Ostrobothnia.

There are considerable differences in the composition of the pebbles and matrices of the various conglomerate occurrences which may have been caused by divergencies in the rocks on the erosion surface. The groun dmas $\mathrm{s}$ is mica gneiss, greywacke or arkosite-like rock but may change into hornblende gneiss or even amphibolite, thereby suggesting volcanic activity (tuff intercalate) in the environment. In Kallislahti, ultrabasic (hornblenditic) intercalates of roughly $1 / 2 \mathrm{~m}$ in thickness have been encountered (Fig. 10). These were interpreted as lava intercalates. Among the pebbles volcanic material amphibolite and leptite predominates. Additionally, mica schist, mica gneiss and veined quartz pebbles occur. In the conglomerates of Savonlinna, plutonic pebbles of both coarse porphyric and evently medium-grained granite have been encountered. This is the only place where plutonic rocks could be found among the pebbles. The amphibolite pebbles derive from the volcanics of the amphibolite complex. It is to be 


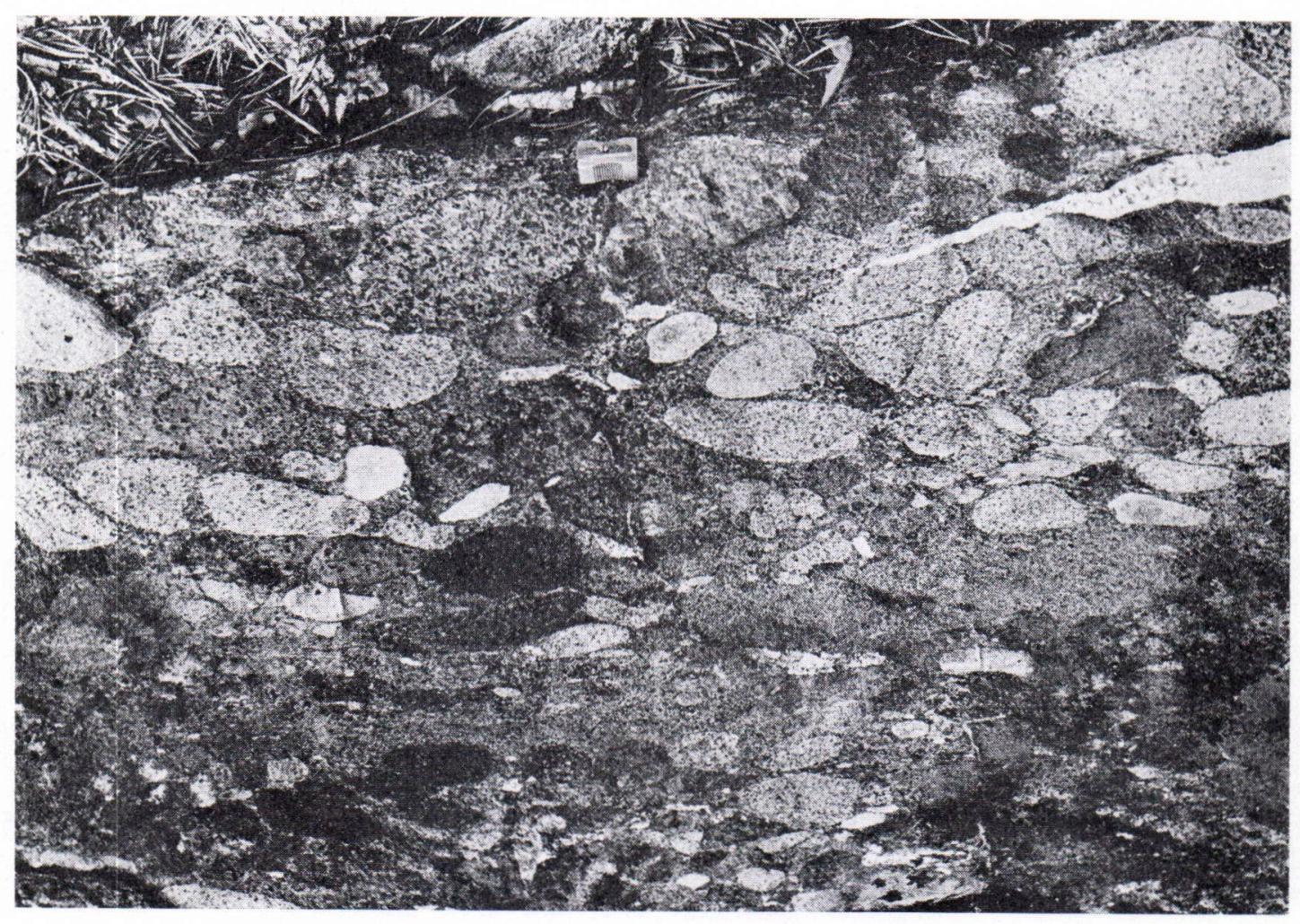

FIG. 9. Conglomerate with pebbles of leptite and amphibolite, Aholahti, Sääminki.

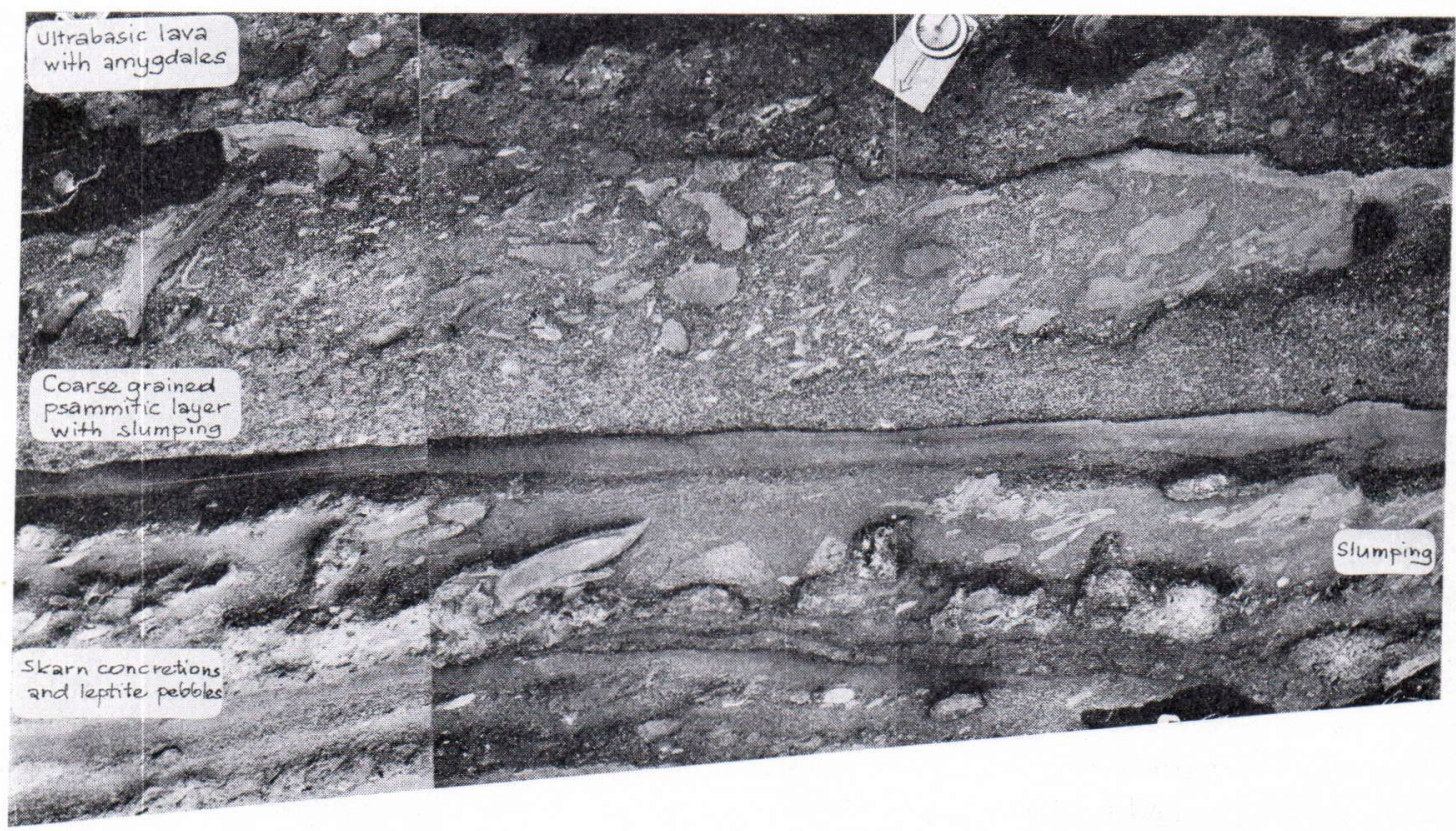

FIG. 10. Conglomerate with an ultrabasic intercalation (top), Antikkalahti, Sääminki. 


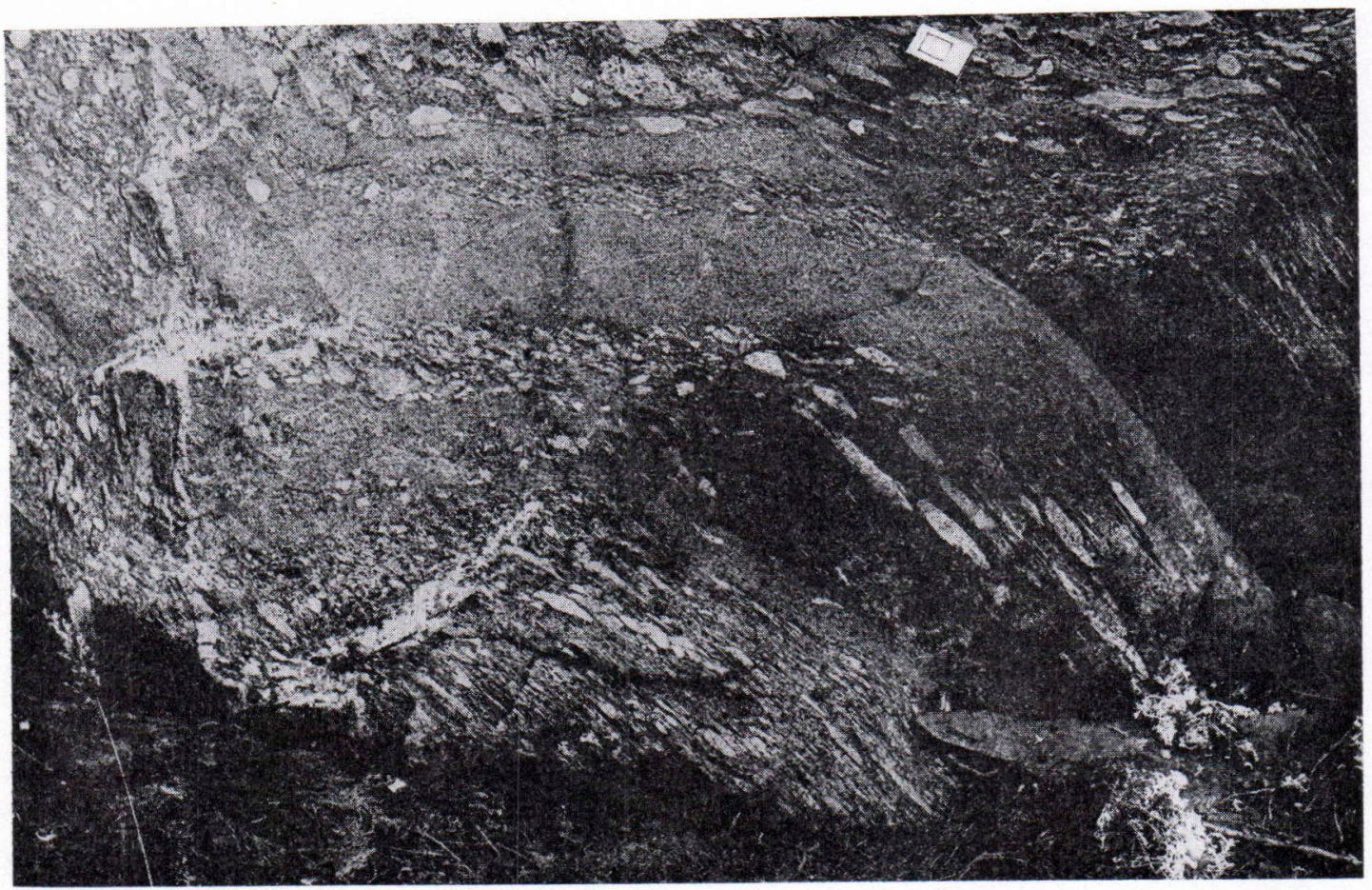

FrG. 11. Conglomerate with strongly elongated pebbles, Kallislahti, Sääminki.

presumed that there was also acid volcanism nearby and that the leptite pebbles are products of this. Beyond the investigated area leptites have been encountered on the Rantasalmi map sheet (K. Korsman, personal communication). The mica gneiss pebbles probably originated in the veined gneiss complex. The origin of the granite pebbles is unknown because analogous rocks have not been found in the area.

The conglomerates of the Haukivesi area exhibit strong axialplane cleavage. Their pebbles are considerably stretched along the a- or b-axis and flattened parallel to the schistosity plane. However, in several of the exposures in favorable sections planes could be observed in which the deformation of the pebbles is almost non-existent. These planes must coincide with the direction of the circular section of the theoretical strain ellipsoid. The conclusion can be drawn from these undeformed sections that the primary form of the pebbles was very varied and often angular. Along the main axis of deformation the pebbles are deformed into rods measuring up to $1.5 \mathrm{~m}$ in length and a few $\mathrm{cm}$ in diameter (Fig. 11).

\section{Savonlinna conglomerate}

(Mineral Compositions Table 2)

The conglomerate occurrences in the area of the town of Savonlinna are regarded as typical representatives of this rock type and were studied in detail. They were termed the Savonlinna conglomerate. On the geological map (Map 5), the Savonlinna conglomerate is located in the horizon between the cordierite gneiss and the mica-bearing skarn-amphibolite. In the area and the vicinity of the town of Savonlinna it has been possible to trace it along the $\mathrm{S}$ edge of the amphibolite bed for about $10 \mathrm{~km}$ from the SE shore of Lake Suurijärvi to the western part of the town. The best exposures are on the $\mathrm{N}$ shore 
of Lake Mertalampi, the SE shore of Lake Pieni Mertalampi and around Lake Suurijärvi. According to observations on the exposures, the conglomerate is at least $20 \mathrm{~m}$ at its widest.

In the conglomerate, the average size of the pebbles along the plane perpendicular to their longitudinal axis is $3 \times 10 \mathrm{~cm}$. The largest fragment encountered measured about $12 \times 50 \mathrm{~cm}$ in this section. In the beds with abundant pebbles, the ratio of pebbles to matrix is $2: 1$. The pebble material in the various exposures is usually analogous in composition whereas the composition of the matrix varies considerably.

The composition of the cong]omerate $\mathrm{ma-}$ $\mathrm{t} \mathrm{r}$ ix varies from fine-to medium-grained hornblende-bearing biotite-plagioclase gneisses and from potash feldspar-bearing mica gneisses to mica-amphibolite. Paler feldspar-rich intercalates and pale-green diopside skarn intercalates $(0.5-$ $10 \mathrm{~cm}$ in thickness) which are often boudinated are encountered in all of the former rocks. In addition, skarn and carbonate concretions are common in the more basic variants. The major minerals of the hornblende-bearing biotite-plagioclasegneiss groundmass are plagioclase (An 20 -30), quartz, biotite and hornblende. The potash feldspar is obviously of secondary origin. Accessories are apatite, sericite, opaque, zircon and carbonate. In structure, the matrix is granoblastic-nematoblastic. The skarn layers are more coarse-grained and characterized by diopside, apatite and titanite.

Among the peb bles leptite predominates. Macroscopically, the leptite pebbles are pale, always fine-grained and oriented. Due to their small grain size, it was difficult to make accurate observations of them in the field. The major minerals are plagioclase (An 25-40), quartz and biotite. There are rare occurrences of hornblende, monoclinic pyroxene and potash feldspar. Accessories are apatite, titanite, chlorite, muscovite, sericite-saussurite-epidote, zircon, opaque, garnet and sagenitic rutile needles. The leptite is granoblastic in structure. In one of the thin sections investigated, a part of the plagioclase content occurs as the slightly porphyric laths of a Karlsbad twin phenocryst. This texture is porbably volcanic.

The amphibolite pebbles are always relatively small with a diameter of only a few $\mathrm{cm}$. They are fine-grained, oriented, dark and always somewhat mica-bearing. Their pebbles are often quartz-bearing and their composition may correspond to that of biotite-bearing hornblendegneiss. The major minerals are hornblende, plagioclase (An 50-60) and biotite. Accessories are opaque, apatite, zircon and chlorite.

The granite and granodiorite pebbles are medium to coarse-grained, massive or slightly oriented and almost hypidiomorphic. They frequently contain large porphyric potash-feldspars. The major minerals are potash feldspar, quartz, plagioclase (An 20-25) and biotite. Hornblende occurs rarely and accessories are apatite, zircon, sericite, opaque, chlorite, carbonate and epidote. The structure is slightly cataclastic.

The mica gneiss pebbles have become strongly deformed into slabs which seem to flow around the more competent pebbles of the plutonic rocks in a conglomerate rich in pebbles. They are microscopically fine-grained. The major minerals are potash-feldspar, quartz, plagioclase (An 20-25) and biotite. Pyroxene and hornblende occur rarely. Accessories are apatite and zircon. Hornblende-bearing biotite-plagioclase gneiss pebbles have also been encountered.

Fine-grained layered intercalated biotite hornblende gneisses containing concretions and devoid of pebbles occur in the conglomerate beds. It is interesting to note that, while the conglomerate pebbles are strongly deformed parallel to the axial plane, the concretions in the pebble-free intercalations lie parallel to the bedding.

In some places, the conglomerate grades into fine-grained greywacke-conglomerate in which fragments corresponding to the large pebbles can be found microscopically. Conglomerate variants of this type occur as intercalated layers associated with the hornblende-rich schist and 
skarn beds. Their rounded fragments are usually less than $2-3 \mathrm{~cm}$ in size and are considerably deformed. In this variety, hornblende-bearing biotite-plagioclase gneiss-, amphibolite- and light quartz-feldspar-fragments are the most common. The matrix is usually either diopsideskarn amphibolite or hornblende-bearing psammitic mica gneiss. In the groundmass, tuff-like structural features have been observed under the microscope.

\section{The metaturbidites of Rantasalmi}

Well-preserved schists, metamorphosed equivalents of interbedded pelitic and psammitic material, were mapped around the parish of Rantasalmi. On the basis of their grain size and variations in sedimentary material, the name greywacke was found appropriate for the psammitic members of those rock types. Nevertheless, for the sedimentary complex as a whole, the term graywacke proved to be unsatisfactory since it does not take into account a highly characteristic association of sedimentary structures which was observed in these rocks. Thus, on the basis of their overall characteristics, the metasediments around Rantasalmi were termed metaturbidites.

The interbedding of psammitic and pelitic material is characterized by graded bedding. The thickness of the beds ranges from a few $\mathrm{cm}$ to one metre. The psammitic parts of the beds are usually both thicker and more homogeneous than the pelitic parts. Calc-silicate concretions are common and occur exclusively in the psammitic parts. The concretions are almost round or, in the outcrop section, elongated and oval shaped. Sometimes concretions form rows, like a string of pearls, parallel to the bedding, and these can be considered as boundinated calc-silicate layers. Also, the more coarse-grained graywacke beds exhibit boundinage structures in places. In the pelitic and more fine-grained psammitic layers, current bedding and cross bedding are frequently visible. In addition, slumping structures have been come across. The more fine- grained psammitic and pelitic layers generally contain sillimanite-andalusite and cordierite as porphyroblasts. Axial plane schistosity is typical of the metaturbidites.

The psammitic and pelitic beds can be distinguished on the basis of their grain size and mineral composition. In this connection, also the graywacke-like layers are included with the psammitic beds because they do not seem to differ much from each other petrographically. The major minerals of the psammitic layers are quartz, plagioclase (An 20-50) and micas (biotite and muscovite). Accessories are zircon, apatite, opaque, sericite, chlorite and titanite. The structure is distinctly blastoclastic. The quartz and plagioclase grains are primary. In addition, rock fragments of the same size composed of plagioclase and quartz have been encountered.

The pelitic beds are micaschists or phyllites in which miniature primary graded bedding can be recognized. Andalusite and cordierite occur as medium coarse-grained porphyroblasts. The dark and thinner upper parts of the beds contain biotite abundantly whereas the pale and thicker lower parts contain equal amounts of muscovite and biotite. The most abundant mineral is quartz. Feldspars are entirely lacking. Accessories are apatite, titanite and opaque which forms bands parallel to the bedding.

On the northern margin of the metaturbidite formation, gneisses are encountered which resemble the Savonlinna cordierite gneisses except that the latter have undergone a stronger degree of metamorphism, and the former are more finegrained with sillimanite occurring in muscovitized nodules as the most abundant aluminiumbearing mineral. The major minerals of the rock are porphyroblastic potash feldspar, granoblastic plagioclase, quartz, biotite and muscovite. In addition, pinitic cordierite pseudomorphs are encountered. Southwards, these sillimanite gneisses grade into metaturbidites with primary structures as the degree of metamorphism and intensity of deformation gradually decreases. 


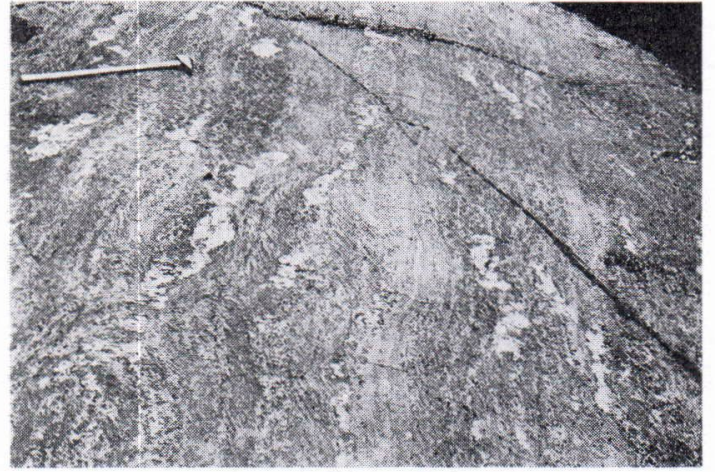

FIG. 12. Typical cordierite gneiss with fine grained psammitic layers, coarse grained strongly recrystallized pelitic layers and pegmatite lenses, Savonlinna.

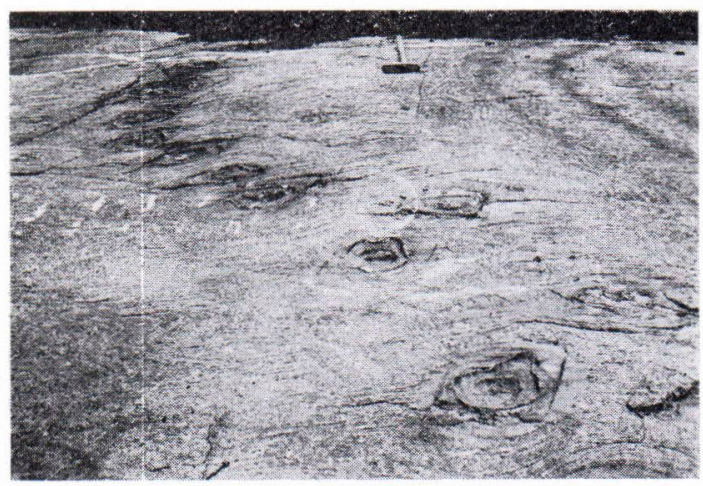

FIG. 13. Concretions and axialplane cleavage in cordierite gneiss, Savonlinna.

\section{The cordierite gneisses of Savonlinna}

The primary material of the Savonlinna cordierite gneiss corresponds apparently to the wellpreserved of Rantasalmi. Most of the metaturbidites formation has undergone a vigorous recrystallization process so that in places there is no sign of primary structures and the different parts of the sedimentary formation have crystallized into homogeneous cordierite gneismasses. However, primary sedimentary strucs tures (psammitic and pelitic layers) have been preserved in sufficient quantities to establish beyond doubt the sedimentary origin of the formation. The pelitic beds have crystallized as coarse-grained cordierite gneisses whereas the psammitic beds often have preserved their habit unchanged ( $c f$. Fig. 12).

The recrystallized cordierite gneiss is coarsegrained. Its weathered surface is rough due to the net-like texture of the offsetting porphyroblastic cordierite grains. The orientation of the obscure pseudomorphic cordierite knots shows the lineation typical of the rock. There are abundant concretions which often form rows like long necklaces (Fig. 13) and display primary bedding even in those parts of the formation in which the recrystallization has homogenized the bedded structure. Axial plane schistosity is visible almost everywhere. The cordierite gneiss is closely associated with garnet bearing, coarsegrained pegmatitic quartz-feldspar-cordieritebodies and lenses which are conform with the planar structures of the rock.

The major minerals of the cordierite gneiss are potash feldspar, quartz, biotite, cordierite and plagioclase (An 30-40). Accessories are sillimanite, garnet, muscovite, opaque, apatite, zircon, chlorite and sericite. The rock is mediumto coarse-grained and granoblastic-lepidoblastic in texture. Of the feldspars, there is an overwhelming abundance of potash feldspar over plagioclase. The potash feldspar is microclinic, coarse perthitic and occurs chiefly as allotriomorphic porphyroblastic grains which contain large amounts of the other minerals of the rock as inclusions in the same way as the cordieriteporphyroblasts. The cordierite is considerably pinitized and in addition contains abundant sillimanite laths and needless as inclusions. The mineral composition of the preserved competent psammitic beds (quartz, plagioclase with An 1842 and biotite) corresponds to that of the psammitic beds of the Rantasalmi turbidites, except that the mineral composition of the former is often potash feldspar-bearing.

Pyrrhotite-bearing intercalates in the cordierite gneiss have been encountered near the southern margin of the Joutsenmäki-Tolvanniemi massif. The cordierite gneiss variants richest in 
plagioclase are to be found in Kallislahti and those richest in quartz in Parkumäki. The latter also contain tourmaline. Fairly common is a sillimanite-rich type of cordierite gneiss on the northern margin of the Parkumäki and Savonlinna cordierite gneiss complex. In this case, the sillimanite occurs as euhedral bunches of needless or fibrous noduless which are parallel to the lineation of the rock. In the northern parts of the Parkumäki cordierite gneiss, muscovite increases at the cost of biotite.

\section{The amphibole- and pyroxene schists connected with the cordierite gneiss}

Ultrabasic amphibole and pyroxene schists have been encountered in the proximity of the conglomerate schist as intercalates in the cordierite gneiss on the SE side of Savonlinna and in the Kallislahti-Parkumäki area. With regard to mineral composition, cummingtoniteplagioclase-schists, cummingtonite-schists, hornblende-schists and olivine-bearing pyroxeneamphibolite-schists can be distinguished. The following major minerals are encountered in varying quantities in the different types: plagioclase, biotite, orthopyroxene, hornblende, cummingtonite and chlorite. Accessories are chlinopyroxene, serpentine, olivine, spinel and carbonate. The schist variants partly grade into one another and partly occur as alternating layers.

\section{INTRUSIVE ROCKS}

The Haukivesi zone belongs to a zone characterized by pyroxene-bearing rocks which follows the distinct lineament swarm running across Finland from Ylivieska on the Gulf on Bothnia towards SE to Parikkala. Ni-Cu mineralizations, of which the most important are Makola, Nivala, Kotalahti, Laukunkangas and Parikkala, are associated with the basic and ultrabasic intrusive rocks along this line. In addition, numerous smaller mineralizations of the same type are known of, e.g. in the Haukivesi area. The Ni-rich Ylivieska-Parikkala zone is indicated in the work of T. A. Häkli (1971) on silicate nickel in Finland.

The intrusive rocks are treated in that chronological order which was obtained during the period of investigation. The division is at the same time both intrusion-tectonic and petrographic. The following intrusion series can be distinguished: 1) The early tectonic series of homogeneous trondhjemite, 2) The mangeritic series of the basic to intermediary intrusive rocks intruded at the time of the main tectonic phase, 3) The coarse porphyric series composed of the late tectonic acidic to intermediary intrusive rocks, 4) Granites, pegmatites and aplites, 5) Basic dykes. The palingenic migmatite-trondhjemite, which belongs chronologically to the mangeritic intrusive series, will be treated in connection with the mangeritic series.

\section{A. Homogeneous trondhjemite series}

(Mineral compositions Table 3)

In the Haukivesi area, the trondhjemites form the most widespread intrusive rocks ranging from the veins in the supracrustal rocks to the homogeneous intrusions dominating the picture of the geological map. Quartzdioritic and dioritic differentiates characterized by hornblende have been observed in connection with the trondhjemites of northern Haukivesi (Härmäniemi, Härmäsaari, Huuhinluoto). In the trondhjemites the foliation is usually more distinct than the lineation. Sometimes, near the contacts of the supracrustal rocks, trondhjemite shows a layered structure which is emphasized by fracturing along the plane of schistosity. These layers are folded concordantly with the host rocks. In northern Haukivesi and Juvola trondhjemite has occasionally been encountered with a curly deformed planar structure (Fig. 14). A similar phenomenon was described by I. Salli (1964, p. 56).

A banded trondhjemite type has been encountered in places at Pisamaniemi in Kangaslampi, at Haukiniemi in Sääminki and in the Varparanta 
TABLE 3.

Mineral compositions of homogeneous trondhjemite, Haukivesi area (integration table method). $\times$ Met in small amounts

\begin{tabular}{|c|c|c|c|c|c|c|c|c|c|c|c|c|c|c|c|c|}
\hline & 1 & 2 & 3 & 4 & 5 & 6 & 7 & 8 & 9 & 10 & 11 & 12 & 13 & 14 & 15 & 16 \\
\hline $\begin{array}{l}\text { Plagioclase } \ldots \ldots \\
(\mathrm{An} \%) \ldots \ldots\end{array}$ & $\begin{array}{l}48.4 \\
(40)\end{array}$ & $\begin{array}{l}37.6 \\
(43)\end{array}$ & $\begin{array}{l}43.2 \\
(32)\end{array}$ & 49.8 & $\begin{array}{l}53.7 \\
(34)\end{array}$ & $\begin{array}{l}52.7 \\
(33)\end{array}$ & 52.3 & $\begin{array}{l}44.3 \\
(35)\end{array}$ & $\begin{array}{r}59.6 \\
(33-45)\end{array}$ & $\begin{array}{l}46.3 \\
(30)\end{array}$ & $\begin{array}{l}63.8 \\
(33)\end{array}$ & 62.9 & 65.0 & $\begin{array}{r}59.8 \\
(22-25)\end{array}$ & $\begin{array}{l}61.6 \\
(25)\end{array}$ & $\begin{array}{r}56.4 \\
(19-24)\end{array}$ \\
\hline Quartz $\ldots . . . \ldots$ & 9.6 & 24.8 & 26.3 & 26.1 & 26.0 & 28.2 & 31.2 & 30.3 & 20.5 & 22.3 & 12.4 & 19.0 & 4.7 & $\begin{array}{r}(22-28) \\
28.9\end{array}$ & 25.8 & 26.2 \\
\hline Potash feldspar. & $\times$ & 1.7 & & $x$ & & $\times$ & $x$ & $\times$ & $\times$ & & & & & 2.9 & 1.9 & 10.9 \\
\hline Hornblende .... & 14.2 & & 2.9 & & 0.7 & 0.3 & & & 2.1 & & 10.2 & 6.9 & 14.1 & 0.7 & & \\
\hline Biotite . . . . . . . & 26.0 & 32.1 & 23.2 & 22.7 & 17.3 & 17.5 & 15.5 & 23.1 & 17.3 & 18.7 & 7.0 & 3.0 & 11.6 & 6.1 & 7.1 & 4.7 \\
\hline Sericite $\ldots \ldots \ldots$ & & & & & 2.3 & & & & & 7.5 & 4.1 & 7.6 & & 1.2 & 2.4 & \\
\hline \multirow[t]{2}{*}{ Accessories ..... } & 1.8 & 3.8 & 4.4 & 1.4 & & 1.3 & 1.0 & 2.3 & 0.5 & 5.1 & 2.4 & 0.5 & 4.6 & 0.4 & 1.2 & 1.9 \\
\hline & 100.0 & 100.0 & 100.0 & 100.0 & 100.9 & 100.0 & 100.0 & 100.0 & 100.0 & 99.9 & 99.9 & 99.9 & 100.0 & 100.0 & 100.0 & 100.1 \\
\hline
\end{tabular}

1. Hornblende (diorite) trondhjemite, Härmäniemi

2. Biotite (diorite) trondhjemite, Harjuranta

\begin{tabular}{|c|c|c|c|c|}
\hline 3. & " & " & , & $"$ \\
\hline 4. & $"$ & » & , & 》 \\
\hline 5. & $"$ & ” & , & ” \\
\hline 6. & $"$ & ") & , & 》" \\
\hline 7. & " & " & & ") \\
\hline 8. & 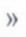 & ” & & Yärmäniemi \\
\hline 9. & ” & 》 & , & isamaniemi \\
\hline
\end{tabular}

$46.3 \%$ dark layers, $53.7 \%$ pale layers
10. Trondhjemite, Varparanta (B. Saltikoff, 1965)

11. Banded trondhjemite, Varparanta (B. Saltikoff, 1965)

12. Same trondhjemite, pale layers (B. Saltikoff, 1965)

13. " " , dark layers

14. "Drop quartz trondhjemite", Varparanta,"

15. " " " " "

16. 


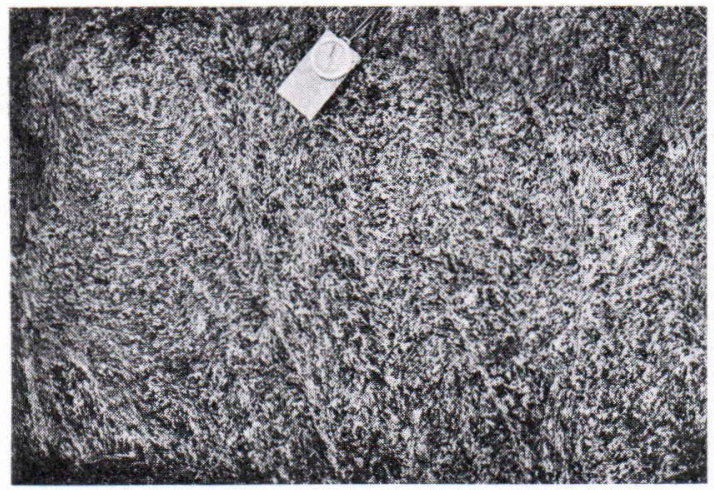

FIG. 14. Trondhjemite with curly deformed foliation, Sääminki, Juvola.

area. The banding is due to the alternation and fingering of the normal pale layers and darker hornblende-bearing trondhjemitic layers with sharp contacts. In Pisamaniemi, the paler and coarser-grained component appears to be the intruding one. The different types of bands are subparallel oriented and their mutual migmatization is parallel to the orientation of the rock.

A variety met in the Varparanta-Haukiniemi area was termed by B. Saltikoff (1965) »dropquartz trondhjemite». This rocktype is characterized by brownish dark quartz spots of $4-5$ $\mathrm{mm}$ in diameter.

Homogeneous trjondhjemite is a pale, medium to medium-coarse-grained and often strongly gneissic (sometimes even granoblastic or almost microporphyric) rock, the major minerals of which are plagioclase (An 25-35, in the drop quartz trondhjemite An 20-25), quartz and biotite. Hornblende and potash feldspar-bearing variations (e.g. drop- quartz trondhjemite) are also encountered. The percentage of accessory minerals is low. They are chiefly antiperthite with short prisms (or potash feldspar), apatite, opaque, zircon, sericite, chlorite and epidote. The texture is indistinctly hypidiomorphic, frequently almost granoblastic and cataclastic features are not uncommon. The plagioclase is fairly idiomorphic and only slightly serizitized. Zoning is weak or lacking. The quartz grains often seem to corrode the plagioclase.

\section{B. Mangeritic intrusive rocks}

\section{(Mineral compositions Tables 4 and 5)}

In the intrusive rock bodies of the mangeritic series, the following rock types can be distinguished on the basis of their petrographic composition: a) Ultrabasic intrusive rocks: peridotite hypersthenite and hornblendite, b) Gabbros: olivine gabbro, norite, pyroxene gabbro, uralite gabbro-hornblende gabbro, c) Diorites: pyroxene-diorite, biotite-hornblende diorite and hornblende-cummingtonite diorite, d) Quartz diorites: pyroxene quartz diorite and hornblende quartz diorite, e) Charnockites. All the forementioned groups of rocks form a comagmatic differentiation series.

On the whole, it can be said that the more basic is the composition of a rock the less abundant it is. The quartz-diorite components dominate in the intrusive rocks of the mangeritic series. The Ni-Cu mineralizations of the area are associated with the basic to ultrabasic differentiates of the mangeritic series. Most of them have been encountered in noritic and hypersthenitic components. The intruding of the mangeritic series appears to have been a multiphase process which took place synkinematically during the main stage of the deformation. The margins of the quartz diorite intrusions often correspond in mineral composition to palingenetic migmatite-trondhjemites. Inspite of the comagmatism and relatively large size of the rocks of the mangeritic series, no regularly differentiated layered intrusions have been observed. It can be presumed that tectonic movements brought about irregular differentiation of the mangeritic magma, thus causing also the products of differentiation to get mixed up.

\section{Peridotite, bypersthenite and hornblendite}

Ultra-basic differentiates are encountered as small scattered occurrences in the Haukivesi archipelago in association with the other mangeritic rocks or as separate individual lenses in the 
TABLE 4.

Mineral compositions of mangeritic intrusive rocks, Haukivesi area (integration table method).

$\times$ Met in small amounts

\begin{tabular}{|c|c|c|c|c|c|c|c|c|c|c|c|c|c|c|c|c|}
\hline \multirow{7}{*}{ 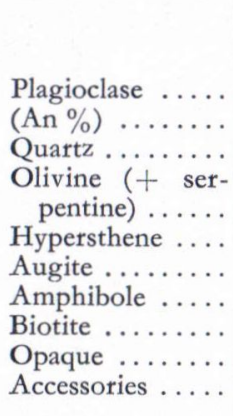 } & 1 & 2 & 3 & 4 & 5 & 6 & 7 & 8 & 9 & 10 & 11 & 12 & 13 & 14 & 15 & 16 \\
\hline & 15.8 & $\begin{array}{r}2.0 \\
(70)\end{array}$ & $\begin{array}{r}\times \\
(75)\end{array}$ & $\begin{array}{r}19.1 \\
(75-90)\end{array}$ & $\begin{array}{r}43.9 \\
(61) \\
3.0\end{array}$ & $\begin{array}{r}37.7 \\
(64) \\
\times\end{array}$ & $\begin{array}{l}40.5 \\
(50)\end{array}$ & $\begin{array}{r}4.9 \\
(42) \\
8.2\end{array}$ & $\begin{array}{l}37.1 \\
(55)\end{array}$ & $\begin{array}{l}35.6 \\
(55)\end{array}$ & $\begin{array}{l}38.2 \\
(70)\end{array}$ & $\begin{array}{l}40.1 \\
(64)\end{array}$ & $\begin{array}{l}25.5 \\
(67)\end{array}$ & $\begin{array}{l}48.1 \\
(66)\end{array}$ & $\begin{array}{r}53.2 \\
(45) \\
2.3\end{array}$ & $\begin{array}{l}40.9 \\
(37) \\
21.2\end{array}$ \\
\hline & $\begin{array}{l}26.5 \\
19.2\end{array}$ & $\begin{array}{l}4.0 \\
8.0\end{array}$ & 4.0 & $\begin{array}{l}47.2 \\
14.9\end{array}$ & $\begin{array}{r}26.1 \\
2.2\end{array}$ & $\begin{array}{l}12.1 \\
26.7\end{array}$ & & 3.3 & 14.4 & & & 35.6 & 24.5 & 9.6 & 8.9 & 3.0 \\
\hline & 37.0 & 85.0 & 94.0 & 12.4 & 15.8 & 15.3 & 39.2 & 70.4 & 25.8 & 2) 43.2 & 15.0 & 11.1 & 11.4 & 21.3 & 10.3 & 10.0 \\
\hline & & & & $x$ & 9.3 & 5.6 & 1) 18.0 & 12.9 & 15.4 & 15.2 & 2.7 & 4.6 & 4.3 & 6.1 & 11.9 & 19.7 \\
\hline & 1.5 & 1.0 & 2.0 & 1.0 & 2.7 & 2.6 & 2.3 & 0.3 & 7.3 & l 6.0 & 1.6 & 3.1 & 25.9 & 3.4 & 4.5 & 2.1 \\
\hline & & & & & & & & & & & 13.1 & 5.6 & 9.1 & 10.1 & 8.6 & 5.2 \\
\hline & 100.0 & 100.0 & 100.0 & 100.0 & 100.0 & 100.0 & 100.0 & 100.0 & 100.0 & 100.0 & 98.7 & 100.1 & 99.7 & 98.6 & 99.7 & 102.1 \\
\hline
\end{tabular}

1) $5 \%$ chlorite

2) partly cummingtonite
1. Peridotite, Härmäniemi
2. Hornblendite, Harjuranta
$3 . \quad$, Harjuranta
4. Olivine norite, Härmäniemi
5. Hypersthene gabbro, Harjuranta
6. Pyroxene gabbro, Harjuranta
7. Uralite gabbro, Harjuranta
8. Hornblende gabbro, Harjuranta

9. Hornblende gabbro, Härmäniemi

10. Hornblende-biotite gabbro, Harjuranta

11. Olivine gabbro, 6 specimens, Joutsenmäki-Tolvanniemi massif

12. Pyroxene gabbro, 13 specimens,

13. Ore-bearing gabbro, 16 specimens,

4. Amphibole gabbro, 23 specimens,

15. Diorite, 5 specimens,

16. Quartzdiorite, 12 specimens, 
TABLE 5

Mineral compositions of mangeritic intrusive rocks, Haukivesi area (integration table method)

$\times$ Met in small amounts

\begin{tabular}{|c|c|c|c|c|c|c|c|c|c|c|c|c|c|c|c|c|c|c|c|}
\hline & 1 & 2 & 3 & 4 & 5 & 6 & 7 & 8 & 9 & 10 & 11 & 12 & 13 & 14 & 15 & 16 & 17 & 18 & 19 \\
\hline Plagioclase .... & $\begin{array}{l}43.5 \\
(38)\end{array}$ & $\begin{array}{l}43.3 \\
(46)\end{array}$ & $\begin{array}{l}45.5 \\
(47)\end{array}$ & $\begin{array}{r}47.8 \\
(46)\end{array}$ & $\begin{array}{r}51.1 \\
(40-60)\end{array}$ & $\begin{array}{r}57.4 \\
(45-55)\end{array}$ & $\begin{array}{l}56.2 \\
(50)\end{array}$ & $\begin{array}{l}53.3 \\
(40)\end{array}$ & $\begin{array}{r}40.5 \\
(45-50)\end{array}$ & $\begin{array}{l}48.6 \\
(54)\end{array}$ & $\begin{array}{l}56.1 \\
(46)\end{array}$ & $\begin{array}{l}47.4 \\
(42)\end{array}$ & $\begin{array}{l}39.9 \\
(37)\end{array}$ & $\begin{array}{l}41.8 \\
(36)\end{array}$ & $\begin{array}{l}41.7 \\
(35)\end{array}$ & $\begin{array}{l}39.6 \\
(35)\end{array}$ & $\begin{array}{l}41.9 \\
(35)\end{array}$ & $\begin{array}{l}54.2 \\
(45)\end{array}$ & 49.5 \\
\hline Quartz ........... & 0.5 & 8.7 & 2.5 & 3.5 & & $x$ & 4.2 & 1.2 & & & $\begin{array}{r}(40) \\
\times\end{array}$ & 5.9 & 14.2 & 15.0 & 16.1 & $\begin{array}{l}\text { (J) } \\
15.4\end{array}$ & 19.8 & $\begin{array}{r}45) \\
8.4\end{array}$ & 170 \\
\hline Potash feldspar & & & & & & & & 8.3 & & & & & 0.1 & & 4.5 & 7.6 & 3.4 & & \\
\hline Hypersthene . & & & & 17.6 & & 18.0 & 28.4 & 25.1 & 7.1 & & & & & & & & & 14.4 & \\
\hline Augite $\ldots . .$. & 0.5 & 9. & & 6.3 & & 11.1 & & & 24.0 & & o. & 2.5 & 8.0 & 6.9 & 1.0 & 5.7 & 6.1 & 2.5 & \\
\hline $\begin{array}{l}\text { Hornblende . } \\
\text { Cummingtonite }\end{array}$ & 26.3 & 8.5 & $\begin{array}{l}19.4 \\
12.5\end{array}$ & 15.9 & 31.6 & 4.5 & & & 17.5 & 37.7 & 20.7 & 34.3 & 1.3 & 6.1 & 6.4 & 1.1 & 0.3 & 2.7 & 16.4 \\
\hline Biotite & 23.4 & 24.8 & 17.3 & 5.8 & 15.2 & 7.7 & 7.9 & 10.2 & 10.4 & 12.7 & 10.1 & 10.3 & 30.7 & 26.5 & 24.6 & 26.7 & 26.1 & 16.8 & 10.2 \\
\hline $\begin{array}{c}\text { Chlorite }(+ \text { seri } \\
\text { cite }) \ldots \ldots \ldots\end{array}$ & & & $\times$ & & & & & & & & & $\times$ & & & & & & & \\
\hline Accessories & 5.8 & 4.9 & 2.8 & 3.5 & 2.1 & 1.3 & 3.3 & 1.9 & 0.5 & 1.0 & 4.5 & 2.1 & 6.7 & 3.7 & 6.0 & 3.9 & 2.4 & 1.0 & 3.8 \\
\hline & 100.0 & 100.0 & 100.0 & 100.4 & 100.0 & 100.0 & 100.0 & 100.0 & 100.0 & 100.0 & 100.0 & 102.5 & 100.9 & 100.0 & 100.5 & 100.0 & 100.0 & 100.0 & 97.5 \\
\hline
\end{tabular}

1. Biotite-hornblende diorite, Harjuranta

2. Pyroxene diorite, Harjuranta

3. Hornblende-cummingtonite diorite, Härmäniemi

4. Hypersthene diorite, Härmäniemi

5. Hornblende diorite, plagioclase-porphyric, Härmäniemi

6. Hypersthene diorite, ",,

7. Hypersthene diorite, Härmäniemi

8. Hypersthene diorite (charnockite), Voinsalmi

9. Pyroxene diorite, Härmäniemi
10. Hornblende-biotite diorite, Pisamaniemi

11. Pyroxene diorite, Pisamaniemi

12. Hornblende diorite, Voinsalmi

13. Pyroxene quartzdiorite, Harjuranta

14. " " "

16.

17.

18. Hypersthene quartzdiorite, Härmäniem

19. Hornblende-cummingtonite quartzdiorite, Voinsalmi 
veined gneiss complex. There are also no signs of any regular, e.g. layered differentiations. Anorthosite differentiates seem to be entirely lacking in the Haukivesi area. There is distinct grading of the ultrabasic rocks into rocks of the gabbro class.

The peridotites are medium-coarsegrained, massive rocks with pale green hornbelnde, hypersthene, augite and olivine as major minerals. The accessories are opaques and apatite. An iddingstite-like serpentine is present mainly as an alteration product of olivine. Antigorite was encountered in only one thin section.

The grading of the peridotite into hornblendite could be followed on one small island ( $\mathrm{x}=$ $6901.9 \mathrm{y}=567.0$ ) in the Kangaslampi area. In this case, roundish dark hornblende phenocrysts appear in the normal peridotite. As they increase in quantity and the peridotite groundmass disappears, the rock changes over to hornblendite. Amphibole is present in the peridotite groundmass as well, but it is much paler than the »hornblenditic» hornblende. Thus, there are two generations of amphibole in the rocks. On the basis of optic determinations, the »hornblenditic» hornblende is richer in iron than the amphibole in the peridotitic groundmass, so that the former must be the product of a later crystallization. According to L. R. Wager et al. (1960), the crystallization of »hornblenditic» hornblende in the peridotite is due to diffusion of ions from the nearby magma chamber in which the separation of the hornblende crystals is under way. The »hornblenditic» hornblende grains enclose the other minerals of peridotite and are thus to a certain extent magmatic porphyroblasts.

The hypersthenites are always medium-grained, pyroxene-gabbro-like rocks which macroscopically are greenish grey and relatively pale. Their major mineral is hypersthene. The other minerals most commonly encountered are opaques, hornblende or plagioclase, although there is usually only one or two of these in addition to hypersthene. The sulphides are always allotriomorphic with regard to hypersthene. In the more heavily mineralized samples they seem to brecciate the silicate minerals. There is also often some biotite in the sulphide-bearing samples.

The hornblendites are coarse-grained and macroscopically monomineralic rocks. The hornblende grains are frequently almost euhedral even though closely packed together. If pyroxene is present, it is principally augite and occurs either as inclusions in the hornblende or together with plagioclase as allotriomorphic grains in the interstices between the hornblende grains. Sometimes minor bright reddish brown biotite or chlorite can be seen.

The Putkilahti basic-ultrabasic intrusive rock complex

The largest ultrabasic intrusive in the Haukivesi area is situated SE of Rantasalmi at Putkilahti in a N-S trending fold zone surrounded by the Rantasalmi metaturbidites. The basic and ultrabasic rocks of Putkilahti differ both petrographically and structurally from the other rocks of the Haukivesi area.

The most wide-spread rocks in the Putkilahti complex are the amphibole-bearing quartz-dioritic and dioritic differentiates which, in the immediate environment of Putkilahti, grade into amphibole gabbros. Within these amphibole gabbros irregular bodies of ultrabasic rocks occur on the E shore of Lake Putkilahti. On many outcrops peculiar-looking intrusive breccias are encountered composed of gabbros and ultra-basic rocks (Fig. 15). In these intrusive breccias the rock components grade into one another and sometimes the peridotite cuts the gabbro, sometimes ultrabasic xenoliths are to be found in the gabbro. The composition of the basic plutonic rocks at Putkilahti is varied and heterogenous. Bedded as well as cloudlike nebulitic structures are encountered in the gabbros (Fig. 16). In addition, the latter contain quartz dioritic-dioritic xenoliths and pale skarn-like 


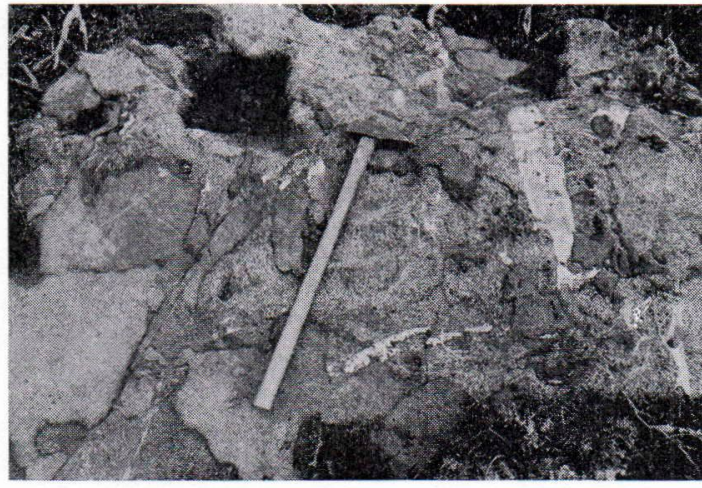

FIG. 15. Intrusive breccia composed of basic and ultrabasic rocks, Putkilahti, Rantasalmi.

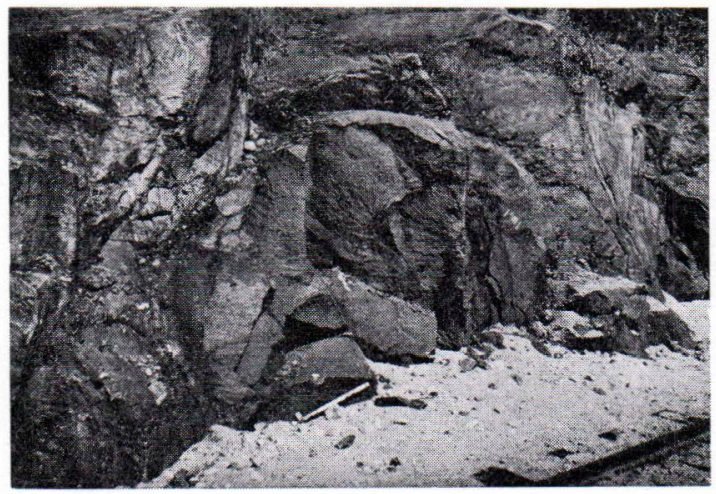

FIG. 16. Rounded and conform norite body in veined gneiss, Kangaslampi, railway cutting $2 \mathrm{~km}$ west of the railway station of Rauhamäki.

angular inclusions composed of quartz, epidote, amphibole and monoclinic pyroxene. The youngest igneous rocks of the area are N-S striking basic dykes.

$\mathrm{H}$ or $\mathrm{nblendite}$ is the dominating ultrabasic differentiate. Its major mineral is a $\mathrm{Mg}$-rich pale edenitic amphibole in addition to which monoclinic pyroxene may also occur. Accessories are titanite, apatite, carbonate and opaque. Also, hypersthenitic and pyroxenitic differentiates have been encountered. The major minerals of the $\mathrm{gabbro}$ are plagioclase (An 3755 ) and the same type of pale edenitic amphibole as in the hornblendite. Either amphibole or plagioclase is the most abundant mineral. In addition, brown biotite and occasional round uralitic pseudomorphs after pyroxene are encountered. Accessories are apatite and opaque.

\section{Gabbros}

The gabbros of the Haukivesi area are mainly norites and pyroxene gabbros which occur as comparatively small intrusions, usually as more basic variants of diorite. They are often individual islets in the archipelago with the result that it has been difficult to make observations concerning their relationship with other rocks. However, in the Kangaslampi and Joutsenmäki-Tolvanniemi areas as well as in some other places, a distinct gradation from pyroxene gabbro by way of pyroxene diorite to pyroxene quartz diorites was observed. Several rootless conform norite bodies only a few metres in diameter have been encountered in the veined gneisses (Fig. 16) of northern Haukivesi.

The norites and pyroxene-gabbros are medium to medium-coarse-grained, greenish or brownish grey massive rocks. Their weathered surface are often corroded which is usually due to the weathering of the plagioclase. The weathered surface and the weathered rock are both of a deep brownish colour due to the domination of brown hypersthene in weathered samples. In fresh samples, the plagioclase is almost without exception a darkish greenish grey and translucent. It occurs either as distinctly or weakly ophitic lathy grains which do not significantly differ in grain size from other minerals. Typical of the norites are the smallish, coarse-grained gabbro pegmatitic segregates (Fig. 17) which have plagioclase, hypersthene, hornblende, biotite and quartz as major minerals.

Occasionally, fine-grained, dark and compact pyroxene gabbro variants are encountered, which are sometimes plagioclase porphyric. They often seem to grade into ophitic gabbros, in which case they may be fine-grained marginal variants of the norites. On the other hand, in some places they resemble the fine-grained gabbro-like basic dyke rocks encountered in the area. 


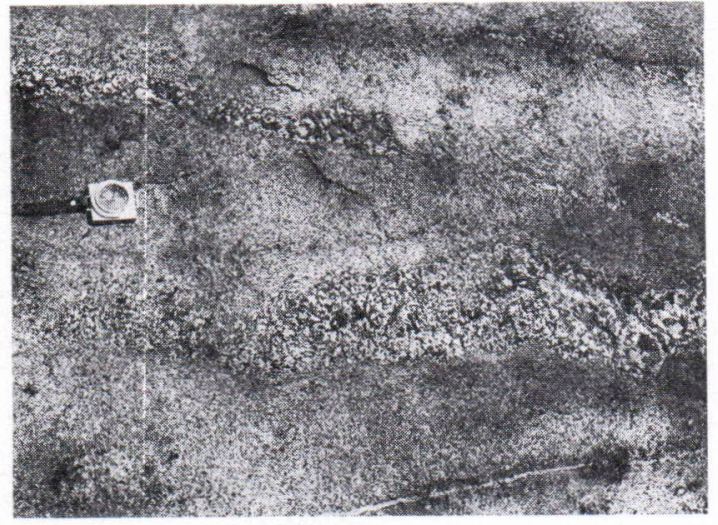

FIG. 17. Micropegmatite segregation in norite, Kangaslampi, Harjuranta.

Primary hornblende gabbros are more rare and seem usually to occur as small lenses separate from the actual coherent intrusive rock formation of the Haukivesi area in which the amphibolebearing gabbros are uralitic. The primary hornblende gabbros occur most abundantly in nothern Haukivesi (Harjuranta, Härmäniemi) and in Putkilahti where they occur as a type of their own. They are coarsegrained almost hornblenditic rocks containing abundant dark-green hornblende. The ophitic structure typical of the pyroxene gabbros is lacking.

The gabbros can be classified into olivine gabbros (olivine norite), norites (hypersthenepredominant pyroxene gabbro), pyroxene (augite + hypersthene) gabbros and uralite gabbros. The crystallization usually seems to have started with plagioclase which has regularly crystallized as doubly twinned laths (albite + Karlsbad). The allotriomorphic occurrence of pyroxene (often a poikilitic network of grains) compared with plagioclase could almost be held as a rule. The features just mentioned suggest that, instead of the usual ophitic texture, the possibility exists of an orthocumulate structure caused by gravitative differentiation (L. R. Wager et al. 1960) in which both plagioclase and olivine are present as cumulus minerals, and pyroxenes and less calcium-rich plagioclases as poikilitic zoned inter-cumulus minerals (Fig. 18).

The major minerals of the olivin e $\mathrm{g}$ a bb r o s are hypersthene, plagioclase (An 75-90), olivine, augite and uralitic hornblende. Mica (reddish brown biotite), chlorite, opaque and cummingtonite occur rarely. The accessories are apatite, opaque, spinel (hercynite) and serpentine. If plagioclase is the most abundant mineral, it occurs ophitically. However, should hypersthene be the most abundant, it is idiomorphic. The latter is often slightly stained by blue-grey or brownish pigment. In some cases, the pigment seems to display an hour-glass structure (Fig. 19). Kelyphitic structures, in which olivine grains are surrounded by an augite seam, which in its turn is surrounded by pale-green amphibolite, are encountered between olivine-augite and palegreen amphibolite (Fig. 20). In the latter, "myrmekitic" radial pyroxene exsolutions are frequently met with. The olivine is either completely unaltered or only slightly serpentinized. In some of the thin sections the pyroxenes are strongly uralitized.

The norites, pyroxene gabbros and uralite gabbros differ from each other in mineral composition only. The hypersthene is usually idiomorphic despite the lathy crystal form of the plagioclase. The pyroxene

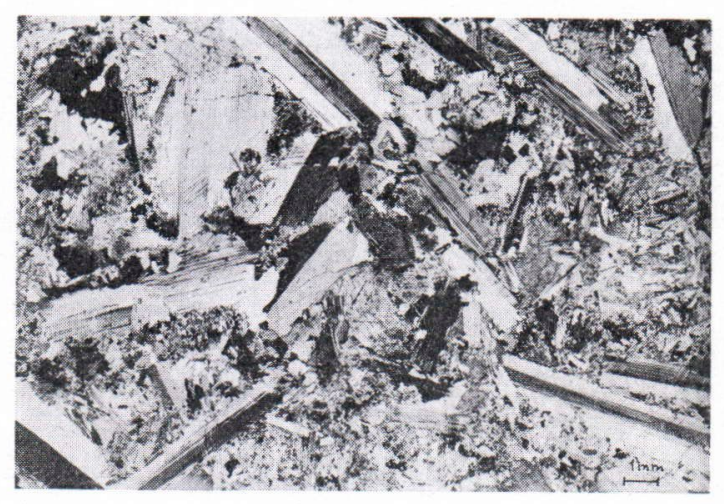

FIG. 18. Pyroxene gabbro with ophitic texture (orthocumulate type): between plagioclase laths xenomorphic or poikilitic pyroxene and allotriomorphic plagioclase, Kangaslampi, Härmäniemi. Nic $\times, 1: 5$. 


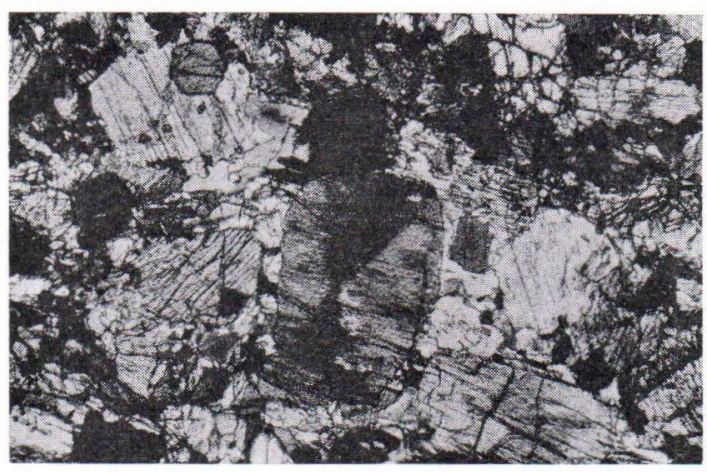

FIG. 19. Hypersthene with hour-glass structure in olivine norite, Kangaslampi, Härmäniemi. Nic $\times, 1: 30$.

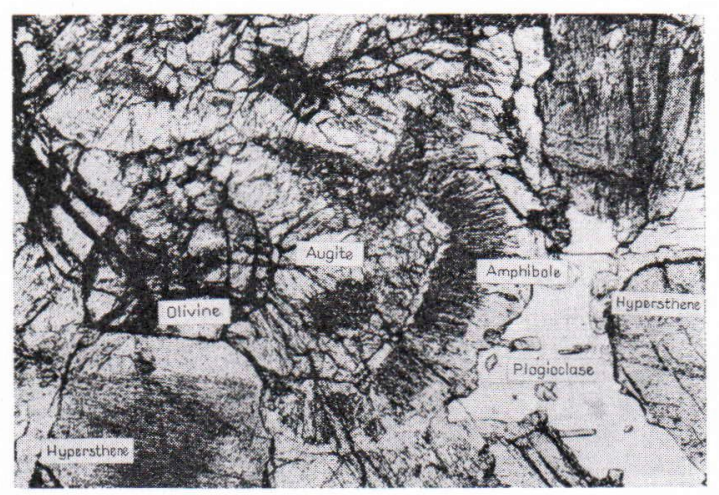

FIG. 20. Keliphitic structure in olivine norite, Kangaslampi, Härmäniemi Nic, $1: 50$.

gabbros are often more heavily uralitized than the norites. Cummingtonite with lamellar twinning is often the alteration product of hypersthene instead of hornblende. Uralite gabbros may be alteration products of both the norites and the pyroxene gabbros. In these, the plagioclase is just as lathy and fresh as in the pyroxene gabbros. Likewise, the orthocumulate structure is more obvious when the pyroxene between the plagioclase laths are completely uralitized. If the degree of alteration has progressed so far that the accompanying biotite is partly chloritized, then signs of sericitization also become visible in the plagioclases.
The Joutsen mäki-Tolvanniemi diorite-and gabbro massif

The large Joutsenmäki-Tolvanniemi gabbrodiorite intrusion in southern Haukivesi is for the most part petrographically similar to the northern occurrences, although only olivine gabbros and hypersthenite variants are encountered as the most basic differentiates of the gabbros. On the geological map, the major part of the intrusion is diorite with gabbroic and quartzdioritic parts. On the basis of their inner structure, the following co-magmatic differentiates can be distinguished: equigranular diorites to gabbros, »diabase-like» gabbros and porphyric diorites.

The grains size of the diorites and gabbros is often fairly coarse and the texture ophitic, although in its dioritic parts it is mostly medium grained, equigranular and locally oriented. The orthopyroxene is bronzite. Strong zoning is typical of the plagioclases. In the plagioclase of the gabbros, the An content varies from An 55-80 and in the diorites from An 30-55. The gabbros and diorites partly grade into one another, but partly the various differentiates have very sharp boundaries between them.

The »diabase-like» gabbros, which are encountered in the gabbro-diorites as xenoliths and products of differentiation, are fine-grained, often ophitic and sometimes »basalt-like» or plagioclase-porphyritic. The weathered surface is dark brownish grey. Both structurally and petrographically these gabbros resemble basic dyke rocks.

The porphyric diorites contain varying amounts of plagioclase phenocrysts which often have zontal arrangements of mafic mineral inclusions. Phenocrysts have been encountered less frequently in the gabbros than in the diorites and quartzdiorites. More dense phenocryst accumulations occur only in the diorites. Porphyric diorite is encountered not only as transition portions but also as veins and bodies cutting and brecciating the gabbro-diorite complex. 


\section{Diorites}

The diorites are medium grained, equi-granular rocks usually characterized by the presence of pyroxene. They contain hornblende-bearing variants more abundantly than the gabbros. The greatest structural difference from the gabbros is the replecement of the ophitic texture by equigranular frequently oriented texture. On the basis of their mineral composition, pyroxene(hypersthene, augite) diorites, biotite-hornblende-diorites and hornblende-cummingtonitediorites can be distinguished. Hornblende and cummingtonite commonly occur in the latter as homoaxial intergrowths, in which case also the sericitization of plagioclase is stronger than usual. In addition, the chloritization of biotite is visiable. The plagioclase (An 38-54) is paler than in the gabbros, for which reason the diorites are macroscopically paler than the gabbros. They are usually hypidiomorphic in texture, but in the more strongly oriented biotite-hypersthenediorites the texture is almost granoblastic in which case the rocks are very reminiscent of the intermediary (magmatic) charnockites. Biotite is more abundant in the hypersthene-bearing than in the hornblende-bearing diorites. Hornblende must be considered for the most part as primary. The pyroxene and hornblende seem to occur chiefly as separate mineral grains, so that there is less uralitization than in the gabbros. Biotite also occurs as a major mineral. Of the accessories, there is a greater abundance of apatite and always a certain amount of quartz.

Plagioclase-porphyric diorite variants have been encountered both as hypersthene- and hornblende-rich types. The largest phenocrysts observed measure $1.5 \times 9 \mathrm{~cm}$. These are Karlsbad twins which are sometimes protoclastically broken and exhibit frequently oscillating and inverse zoning. Orthocumulatic structural features are usual in the porphyric diorite variants.

\section{Quartzdiorites}

Both pyroxene- and amphibole-bearing types belong to the quartzdiorite. The fine- to mediumgrained dark pyroxene-bearing variants are more strongly oriented and they grade distinctly into pyroxene diorites and pyroxene gabbros (Kangaslampi).

The major minerals of the pyroxene-bearing quartzdiorites are plagioclase (An 35-45), biotite, quartz, hornblende and hypersthene. Occasionally a small percentage of secondary potash feldspar is encountered. Accessories are apatite, titanite, zircon and needle-like sagenite. Typical of the hornblende are the myrmekitic intergrowths with plagioclase and quartz.

The grain size of the hornblende-bearing quartzdiorites ranges from medium to mediumcoarse-grained so that they are more coarsegrained than the corresponding pyroxene-bearing quartzdiorites. The plagioclase is of a considerably paler shade, being usually yellowish or yellowy-brownish-grey on its weathered surface. Cummingtonite is often encountered alongside hornblende. The amphibole-rich and hypersthene-bearing quartzdiorites are usually more distinctly hypidiomorphic, whereas the oriented pyroxene quartzdiorites are more granoblastic.

\section{Charnockites}

In the following, charnockites are taken to mean fine-medium grained gneissic rocks which petrographically are hypersthene dioritic-quartzdioritic and which differ from the corresponding normally composed intrusive rocks chiefly on the basis of their structure. They are oriented or distinctly foliated, dark brownish and sometimes biotite porphyric rocks. They frequently bear a strong resemblance to gneissic pyroxene quartzdiorites from which it is sometimes difficult to distinguish them.

The intermediary charnockite is best represented by a gneissic hypersthene-bearing fine- to medium-grained rock which has a quartz-dioritic mineral composition and also contains potash feldspar. The major minerals are plagioclase (An-40), hypersthene, biotite and potash 


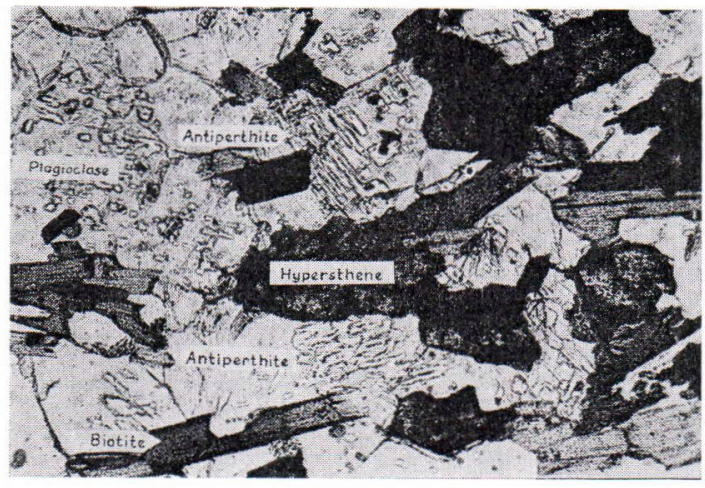

FIG. 21. Plagioclase with abundant antiperthite in intermediary charnockite, Rantasalmi, Voinsalmi. Nic $\times, 1: 50$.

feldspar. Either a small percentage of quartz is encountered or then it occurs accessorily together with opaque and apatite. The plagioclase has either scarce or abundant albite twinning but occurs as an almost granoblastic mass. Antiperthite with short prisms (Fig. 21) is in places present in such large quantities that it forms a netlike texture covering $30-40 \%$ of the area of the plagioclse grains. This is a typical feature of the magmatic charnockites according to K. Parras (1958). In addition to antiperthite, potash feldspar is encountered as transparent allotriomorphic grains in which neither perthite nor microcline textures have been observed. The hypersthene is usually unaltered even though in the fissures and at the margins it is tarnished by a dark pigment. However, in places, uralite or a yellowish mica are encountered as alteration products of hypersthene. The latter occurs regularly as ragged xenomorphic grains which from a netlike texture in the same way as the pyroxene in the metamorphic rocks (sponcy crystals). The biotite is strongly pleochroic and nematoblastic.

\section{Migmatite trondhjemite}

\section{(Mineral compositions Table 6)}

The so-called migmatite trondhjemites are encountered in the same complex together with the rocks of the mangeritic series in the northern and central Haukivesi areas, whereas south of the line Rantasalmi-Haukiniemi--Varparanta in the southern Haukivesi area this rock is almost entirely lacking. The most distinct migmatite trondhjemite zones run along the lines Harjuranta-Härmäsaari-Toivosaari, the new canal of Oravi-Juvola-Laukunkangas and Voinsalmi-Torasalo-Linnansaari. It is fundamental to this rock that it only occurs as migmatitic rock-mixtures, e.g. as the medium- to medium coarse-grained igneous ground mass of the various migmatites around the mangeritic intrusions and also occasionally in the Kangaslampi area in the veined gneiss complex as masses which grade into veined gneisses.

V. Hackman (1933) mentioned a grey-white granite brecciating the rocks which he called the gabbro-granites of the Haukivesi area. However, he also made it clear that this younger granite, which obviously corresponds to the heteorogeneous migmatite trondhjemite, grades into other gabbro granites. Hackman also mentioned the garnet content of this rock and states: »It is strange that this grey-white breccia-forming granite only contains oligoclase feldspar. There is abundant quartz and a very varying amount of biotite».

The mineral composition of the migmatite trondhjemite at its purest is similar to that of the homogeneous gneissic trondhjemite. The major minerals are plagioclase (An 30-34), quartz and biotite. However, garnet composed of almandite-pyrope $(70: 30)$ is often present. Cordierite-bearing varieties have also been encountered in the Juvola-Haukiniemi area. In the hypersthene-gneiss zone of Kangaslampi, migmatite trondhjemite is hypersthene-bearing. There are random occurrences of blue-green hornblende. Potash feldspar and antiperthite are not uncommon. Accessories are chlorite, apatite, zircon, sagenite, carbonate and titanite. Plagioclase is grey on fresh surfaces and often sericitized in potash felspar-samples. Quartz is macroscopically bluish and corodes all the other minerals in a rock. It differs from the quartz of the corres- 
TABLE 6

Mineral compositions of migmatite trondhjemite, Haukivesi area (integration table method) $\times$ Met in small amounts

\begin{tabular}{|c|c|c|c|c|c|c|c|c|c|}
\hline & 1 & 2 & 3 & 4 & 5 & 6 & 7 & 8 & 9 \\
\hline \multirow{9}{*}{ 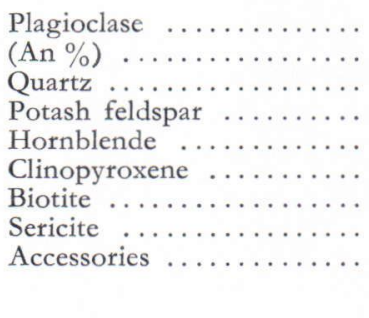 } & 59.8 & 50.4 & 31.6 & 33.1 & 26.5 & 40.4 & 30.9 & 26.2 & 45.8 \\
\hline & (34) & (33) & $(30)$ & (32) & (22) & (32) & (36) & (33) & (37) \\
\hline & 29.4 & 35.5 & 54.4 & 37.0 & 18.0 & 32.6 & 16.7 & 33.4 & 37.5 \\
\hline & & $x$ & $x$ & 25.2 & 49.0 & 18.8 & 30.2 & 36.6 & \\
\hline & & 2.0 & & & & & 10.0 & & 0.04 \\
\hline & & & & & & & $\times$ & & \\
\hline & 10.3 & 10.9 & 13.4 & 2.8 & 6.5 & 1) 7.6 & 7.3 & 3.2 & 14.5 \\
\hline & 0.5 & 1.2 & 0.6 & 1.9 & 0.3 & 0.6 & 4.9 & 0.6 & $\begin{array}{l}1.5 \\
1.7\end{array}$ \\
\hline & 100.0 & 100.0 & 100.0 & 100.0 & 100.3 & 100.0 & 100.0 & 100.0 & 101.0 \\
\hline
\end{tabular}

1. Migmatite trondhjemite, Harjuranta

1) Chlorite met with

\begin{tabular}{|c|c|c|c|}
\hline 2. & $\gg$ & $\gg$ & , \\
\hline 3. & 》) & $»$ & , \\
\hline 4. & 》) & ") & , \\
\hline 5. & 》) & $»$ & , \\
\hline 6. & $\gg$ & $\gg$ & , \\
\hline 7. & $»$ & $\gg$ & , \\
\hline 8. & 》 & 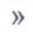 & , \\
\hline
\end{tabular}

9. Heterogeneous trondhjemite, obviously migmatite trondhjemite (B. Saltikoff 1965).

ponding early tectonic trondhjemite in that it is not granulated. On a small scale, migmatite trondhjemite is heteorogeneous and either massive or banded due to the uneven distribution of the biotite. Signs of extremely strong deformation are particularly clear in schollenmigmatite zones.

\section{Hybridic granodiorite}

Hydridic granodiorite is encountered in association with a mangeritic intrusive rock series as a NW-SE oriented and uniform zone extending from Teemassaari via Torasalo (Voinsalmi) to the northern side of Linnansaari. It cannot be called an independent rock genetically, but an altered quartzdiorite, the mineral composition of which in its present state corresponds to granodiorite. The contacts with the quartzdiorites are gradual. This can be plainly seen in the exposures where the reddish "granitic» material intrudes the quartzdiorite rocks as numerous thin veins and nebulitic bodies thus causing them to be heterogeneous and many-coloured (Fig. 22). The result is a hybridic, mediumgrained, massive and often colourful granodiorite (brick-red potash feldspar veins and spots on a blue-grey quartz-plagioclase groundmass).

The major minerals are plagioclase (An 2334), quartz, potash feldspar, hornblende and biotite. The potash feldspar is distinctly secondary and displaces plagioclase. Myrmekitic structures are typical both in the plagioclase and potash feldspar grains. The hornblende is a blue-green type and the biotite dirty brown in colur. Accessories are apatite, zircon, and opaque.

The metasomatic alteration of the forementioned mangeritic quartz-diorite (chiefly the addition of potash feldspar and quartz as well as the formation of blue-green hornblende) seems to have taken place during the closing stage of the major folding period. The metasomatically migrated potash-rich components probably originate from the coarse-porphyric granite-granodioritic rocks. 


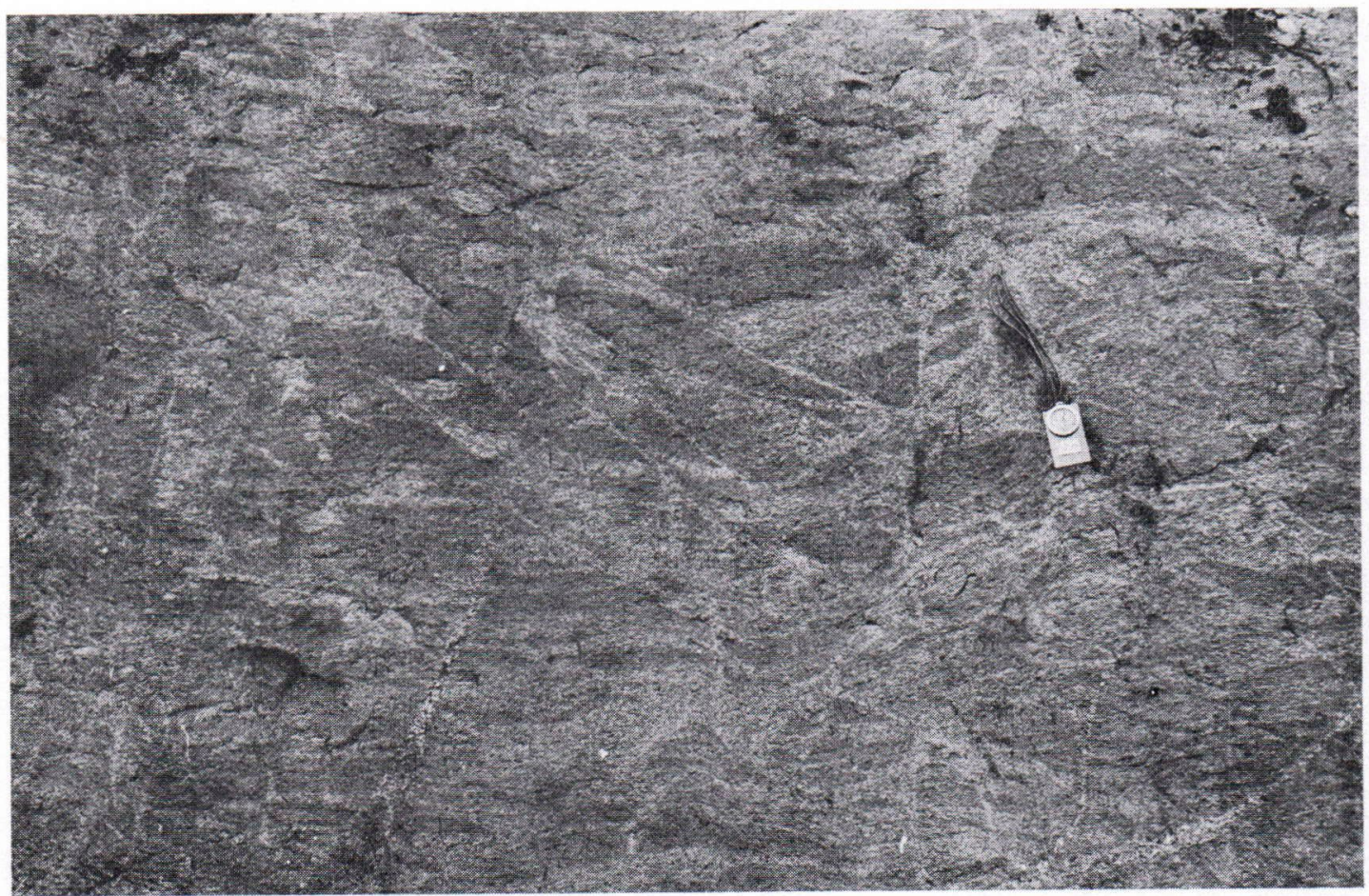

FIG. 22. Hybridic granodiorite: reddish granitic material intrudes quartzdiorite, Teemassaari, Rantasalmi.

\section{Coarse-porphyric hypersthene-bearing granodiorite}

The coarse-porphyric rocks form the next younger intrusive rock suite of the Haukivesi area. Petrographically, they range from granites through granodiorites to quartzdiorites. As a whole, the rock suite is very uniform and their emplacement must be considered to have taken place simultaneously.

Typical of the coarse-porphyric rocks are their discordant mode of occurrence, eruptive breccias and considerable metasomatic mixing with the host rocks in the contact zones. Granitic variants occur chiefly in the Varkaus-KangaslampiJoroinen area where porphyric granite has been observed to grade into coarse-grained granite and further into granite pegmatite. The coarseporphyric rocks of the central Haukivesi area are grano-quartzdioritic and occasionally almost coarse-grained diorite in composition in which case their porphyric nature is obscured but their coarseness preserved. The corresponding rocks of the Joutsenmäki--Tolvanniemi area are granite-granodiorites.

The quartz-granodioritic variants frequently disintegrate whereas the granitic ones never do.

The weathered surface of the coarse porphyric granites (Mineral compositions Table 7) is either pure white or reddish due to the colour of the potash feldspar. Sometimes, coarse porphyric granite is so rich in potash feldspar that it is like a porridge of packed and oriented potash feldspar crystals. The potash feldspar phenocrysts are idomorphic Karlsbad twins (averaging $1 \times 2,5$ $\mathrm{cm}$ in size) which usually have an oriented texture conform with the structures of the environment. The major minerals are potash feldspar, plagioclase (An 24-26), quartz and strongly pleochroic biotite. Very iron-rich hypersthene and hornblende are encountered 
sporadically. The fact that these minerals usually occur in the proximity of pyroxene gabbro contacts shows that they are products of contamination. Accessories are apatite, opaque, sericite, chlorite, zircon and titanite. Plagioclase and quartz myrmekites are abundant. The phenocrysts of porphyric potash feldspar are porphyroblastic.

The coarse-porphyric granodiorites differ from the granitic variants in that the dark minerals (hypersthene and hornblende) are more abundant and the amount of plagioclase increases while it also occurs as porphyric phenocrysts. The plagioclase has an An-content of 26-35\%. In the centre of Haukivesi a pale plagioclase rim has been encountered in the potash feldspar grains. The hypersthene is distinctly pleiochroic and commonly tarnished along the cleavages. Only in places has it altered into a yellowish mica mineral. Hornblende and biotite are intensely coloured and strongly pleochroic.

The coarse-porphyric quartz-diorites are throughout brownish in colour and usually plagioclase porphyric (An 35-40). However, the more basic variants are often weakly porphyric. A clear distinction between the granoand quartz-dioritic variants cannot be drawn, because the hypersthene-bearing granodiorites are often just as brown in colour as the quartzdiorites. When potash feldspar is lacking and quartz is comparatively scarce, the rock has been called quartzdiorite.

The porphyric potash feldspar phenocrysts of the porphyric granite in the Kangaslami-...Varkaus area are orthoclase (triclinicity zero, $3 \mathrm{x}$-ray determinations). On the other hand, the triclinicity of the potash feldspar phenocrysts of the porphyric grano-quartzdiorites in central Haukivesi and Joutsenmäki-Tolvanniemi varies from $0.83-0.90$ (4 determinations), so that they must be considered chiefly as triclinic microclines. Determinations made from the granite-granodiorite massif of Torasalo represent intermediary types (triclinicity $0.10-0.64,2$ determinations).

\section{Granite, pegmatites and aplites}

\section{(Mineral compositions Table 7)}

Petrographically, granitic rocks can be classified according to their age, ie. from oldest to youngest, as follows: equigranular granites, pegmatitic and aplitic granite veins, fine-grained reddish granite veins. Pegmatitic and aplitic trondhjemite veins are also dealt with in this context.

Whenever the forementioned rocks cut the rocks of the mangeritic series in veins, a 10 $30 \mathrm{~cm}$ wide seam, which is darker than its environment, occurs on both sides of the veins. The phenomenon is caused by the fact that pyroxenes were uralitized near the acid veins and the abundance of mica is higher than normal.

Equigranular coarse granite is encountered at Rantasalmi and as several small occurrences in the veined gneiss complex of Northern Haukivesi, where they are pegmatites or coarse grained granite variants. Discordant granite-pegmatite veins are common over the whole area. Quartz is frequently enriched in their coarser cores.

The mineral composition of the granite pegmatites is as follows: microcline (x-ray determination), quartz, plagioclase (An 10), muscovite and biotite. The more common accessories are garnet and tourmaline. The abundance of plagioclase decreases with the increasing coarseness of the material. Muscovite is much more common than biotite. Quartz is sometimes very idiomorphic. Typical of the granite-pegmatite bodies are the graphic potash feldspar-quartz intergrowths which may reach several square metres in size. The mica in association with the latter is solely muscovite.

The trondhjemite pegmatite and aplite veins are medium-coarse to coarse-grained, grey-white cross-cutting veins which contain plagioclase as the only feldspat. The major minerals are plagioclase, quartz and partly chloritized biotite. Accessories are hornblende, sericite, opaque, apatite, zircon and antiperthite. The mineral 


\section{Table 7}

Mineral compositions of coarse porphyric granite, pegmatites, aplites and fine grained granitic veins, Haukivesi area (integration table method).

\begin{tabular}{|c|c|c|c|c|c|c|c|c|c|}
\hline \multirow{7}{*}{ 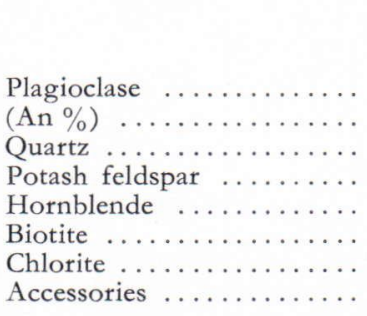 } & 1 & 2 & 3 & 4 & 5 & 6 & 7 & 8 & 9 \\
\hline & $\begin{array}{l}29.9 \\
(25)\end{array}$ & $\begin{array}{l}28.2 \\
(24)\end{array}$ & $\begin{array}{l}13.1 \\
(26)\end{array}$ & $\begin{array}{l}24.9 \\
(25)\end{array}$ & $\begin{array}{l}20.5 \\
(26)\end{array}$ & $\begin{array}{l}22.4 \\
(15)\end{array}$ & $\begin{array}{r}31.1 \\
(8)\end{array}$ & $\begin{array}{r}42.7 \\
(27-28)\end{array}$ & 44.7 \\
\hline & 18.3 & 21.3 & 27.4 & 27. & 34.9 & 33.7 & 27.6 & 29.9 & 29.3 \\
\hline & 42.2 & 38.8 & 55.8 & 36.9 & 35.8 & 42.3 & 37.4 & 20.4 & 6.1 \\
\hline & & & 1.3 & & & & & & \\
\hline & 8.1 & 10.7 & 2.1 & 8.7 & 7.7 & 1.5 & & 4 & 18.7 \\
\hline & 1.5 & 1.0 & 0.3 & 1.6 & 1.1 & 0.1 & 3.8 & 1.5 & 1.3 \\
\hline & 100.0 & 100.0 & 100.0 & 99.2 & 100.0 & 100.0 & 99.9 & 99.9 & 100.1 \\
\hline
\end{tabular}

1. Coarse porphyric granite, Harjuranta

2. 》 》 , ”

3. Pegmatite granite, Harjuranta

4. " " , "

5. " " , "

6. Aplitic granite, Härmäniemi

7. " " Pisamaniemi

8. Fine grained granite vein, Harjuranta

9 . 》 》 , 》

composition indicates trondhjemitic composition and, indeed, this type of pegmatite has been interpreted as the final crystallization product of the trondhjemitic rocks.

The fine-grained reddish granite veins represent the last intrusion phase according to contact observations. They have been observed to cut all the rock types including the coarse porphyric granite, pegmatites and basic dyke rocks. The thickness of the veins ranges from $0.1-3.0$ metres. They occur most abundantly in the Harjuranta area and usually strike from east to west. The major minerals are plagioclase (An 15-27), quartz, potash feldspar and micas (biotite and chlorite). Accessories are apatite, titanite, opaque, epidote and zircon. The plagioclase is pigmented, strongly sericitized and saussuritized. There is very little polysynthetic twinning. Biotite is partly chloritized. The structure is chiefly hypidiomorphic. Sometimes, white porphyric microcline phenocrysts ( $\mathrm{x}$-ray determination) are associated with the marginal parts of acid veins of this type.

\section{E. Basic dykes}

(Mineral compositions Table 8)

The basic dykes investigated in this study represent pyroxene-hornblende-bearing and frequently slightly ophitic gabbroic amphibolite dykes among which diabase and plagioclase- or uralite-porphyrite variants are encountered. They chiefly resemble the hornblende diabases of North Savo described by W. W. Wilkman (1925). On the basis of their varying contact relations, the basic dykes probably intruded in several phases.

The major minerals are most frequently plagioclase (An 50-80), hornblende, hypersthene, cummingtonite and biotite. Accessories are opaque, sericite, apatite, zircon and carbonate. Hornblende and cummingtonite often occur as homo-axial intergrowths. The structure is either massive or slightly ophitic.

A remarkable feature is that some of the dykes are completely intact at their contacts whereas others are fractured to varying degress, either 
Table 8

Mineral compositions of basic dykes, Haukivesi area (point counting method) $\times$ Met in small amounts

\begin{tabular}{|c|c|c|c|c|c|}
\hline \multirow{2}{*}{. } & \multirow{2}{*}{1} & \multirow{2}{*}{2} & \multicolumn{2}{|c|}{3} & \multirow{2}{*}{4} \\
\hline & & & $\mathrm{a}$ & $\mathrm{b}$ & \\
\hline \multirow{7}{*}{ 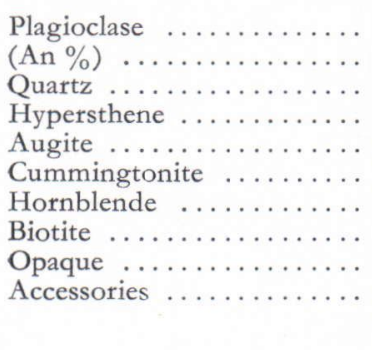 } & $\begin{array}{l}54.4 \\
(67)\end{array}$ & $\begin{array}{r}38.3 \\
(55-63)\end{array}$ & $\begin{array}{l}44.7 \\
(40)\end{array}$ & $\begin{array}{l}44.7 \\
(35)\end{array}$ & $\begin{array}{l}41.62 \\
(45)\end{array}$ \\
\hline & & 16.7 & ? & & \\
\hline & 11.0 & & $\begin{array}{r}2.1 \\
\times\end{array}$ & & \\
\hline & 26.2 & 36.2 & $\begin{array}{r}x \\
33.6\end{array}$ & 32.9 & 54.28 \\
\hline & 5.5 & 6.7 & 1. 8 & 2.2 & \\
\hline & 1.9 & & $\begin{array}{r}6.4 \\
11.4\end{array}$ & $\begin{array}{l}7.2 \\
9.6\end{array}$ & 1) 4.10 \\
\hline & 100.0 & 100.0 & 100.0 & 100.0 & 100.0 \\
\hline
\end{tabular}

1) Magnetite and ilmenite

1. Fine grained gabbroid dyke, Härmäniemi

2. Complex "basic dyke, Joutsenmäki-"Tolvanniemi massif,

a) Fine grained dark component

b) Fine grained paler component

4. Hornblende diabas, Varpaisjärvi, Niemisenmäki (W. W. Wilkman, 1925)

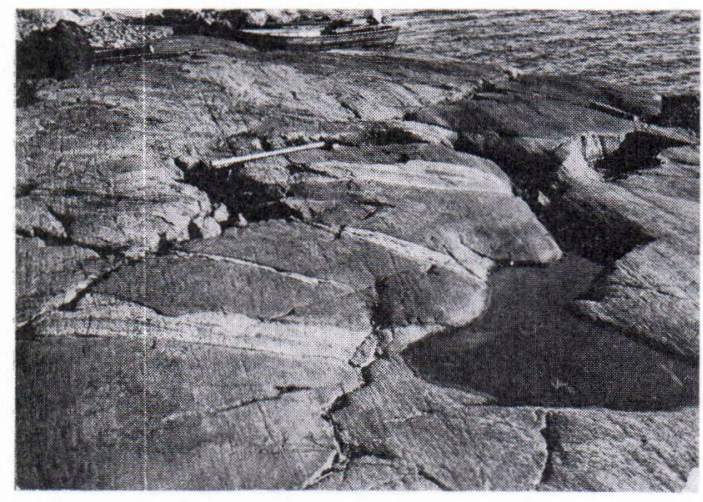

FIG. 23. Boudinated basic dyke which cross-cuts migmatite but is simultaneously intruded by the migmatitic host rock, Kangaslampi, Härmäniemi, Haapiosaari.

migmatized by the acid veins or entirely boudinated. An example of this the $1.5 \mathrm{~m}$ wide fine-grained basic dyke at Härmänniemi Haapionsaari which as a whole, cross-cuts the distinctly trondhjemite-dominant migmatite. However, the dyke is cut up into pieces of even width so that the migmatitic host rock appears to flow with all its schist fragments through the broken dyke (Fig. 23). The dykes vary in thickness from $5 \mathrm{~cm}-2.5 \mathrm{~m}$ (average $60-80 \mathrm{~cm}$ ). There is frequently a $5-40 \mathrm{~m}$ thick fine-grained cooling contact along the boundaries of the dykes.

Complex dykes are met with in the Joutsenmäki-Tolvanniemi area as a type of their own containing two or more components. Usually complex dykes of this type are composed of dioritic and quartz dioritic components which differ from each other on the basis of the darkness of their colour and their grain size. The amounts and rations of the different components vary within the dykes and bring about diverse patterns sometimes with sharp contacts and sometimes grading into one another.

In his explanation to the Savonlinna map sheet, V. Hackman (1933) mentions basic dykes on an island on Lake Äimisvesi in the Haukivesi area and considers them to be postjotunian dykes belonging to the lamprophyric class. He has also described a pyroxene-bearing diabase dyke from the island of Anttonen. 
III PRODUCTS OF MIGMATIZATION

\section{A. Migmatites produced by homogeneous trondhjemite}

The migmatization brought about by the early tectonic homogeneous trondhjemite does not extend beyond the supracrustal rocks. There are exceptions in the Varparanta and Savonlinna trondhjemites, where the trondhjemite contains fragments of quartzdiorite, gabbro and hornblendite. The latter rocks contain hornblende and biotite as mafic constituents. The contacts of these xenoliths with the trondhjemites are always sharp. Trondhjemite also often contains conform lamellae of mica-gneiss inclusions (Fig. 24). Inspite of the locally almost massive texture of the trondhjemite, the orientation of the forementioned fragments is preserved. The intrusion of the homogeneous trondhjemite seems to have taken place mainly along the planes of layering and foliation forming veined gneisses and banded migmatites with amphibolites. The contacts encountered with the supracrustal rocks are conform. There is no eruptive breccia formation.

\section{B. Migmatites produced by mangeritic intrusions}

The migmatizing influence of the rocks of the mangeritic series is also very slight. There are sporadic fragments of supracrustal rocks and the older trondhjemite in the ultra-basic and basic differentiates. Fragments are much more common in the quartzdiorites and they often trend distinctly in accordance with the schistosity of the environment. Occasionally, more basic fragments are encountered in the quartz-diorites and diorites, although their number remains surprisingly low.

Cordierite-gneiss and amphibolite-hornblende gneiss xenoliths have been encountered occasionally in the gabbro and diorite massif of Joutsenmäki-Tolvanniemi. The cordierite, garnet and graphite in the gabbro and diorites are probably the assimilated relics of supracrustal fragments.

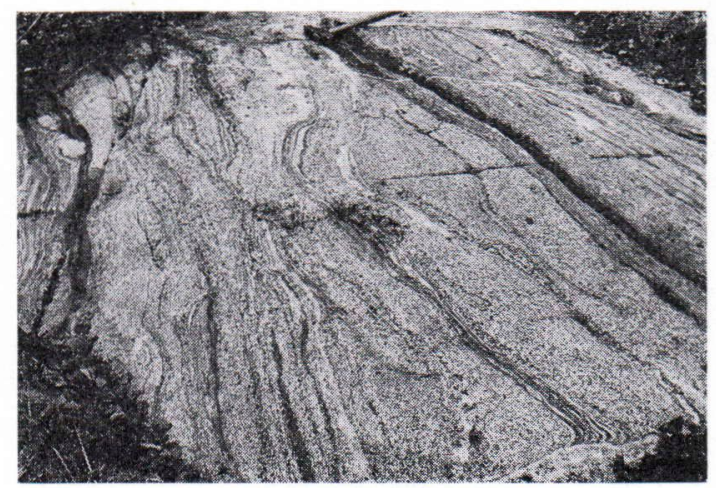

FIG. 24. Homogeneous trondhjemite with conform mica gneiss inclusions, Kangaslampi, Harjuranta.

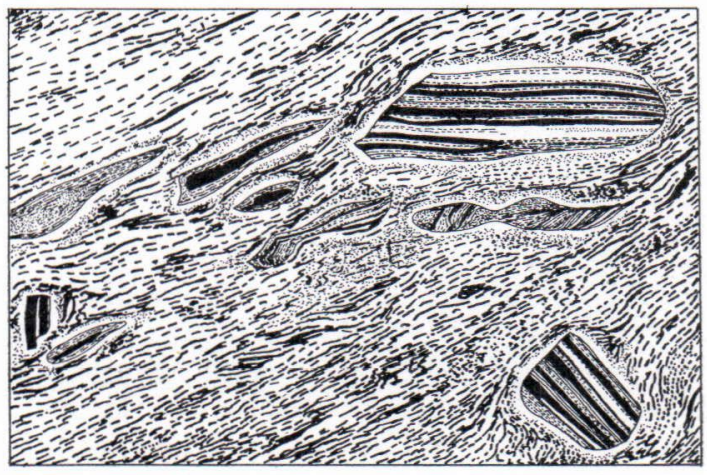

FIG. 25. Schollenmigmatite: diopside amphibolite fragments in migmatite trondhjemite, Rantasalmi, Torasalo. Size $1 \times 1.5 \mathrm{~m}$.

\section{Migmatites produced by migmatite trondhjemite}

The predominating intrusive rock type of the northern Haukivesi area, the hypersthene-bearing quartzdiorite, exhibits a transition zone in its contact zone against veined gneiss where homogeneous quartzdiorite grades into a hybridic variety of quartzdiorite containing nebulitic remains of older digested rocks. The closer the quartzdiorite is to the contact, the more heterogeneous it becomes until it partly changes into a trondhjemite. This rock frequently contains parallel oriented supracrustal inclusions which increase in number towards the contact until the rock becomes a typical schollenmigmatite (Fig. 25). The schollenmigmatite is one of 


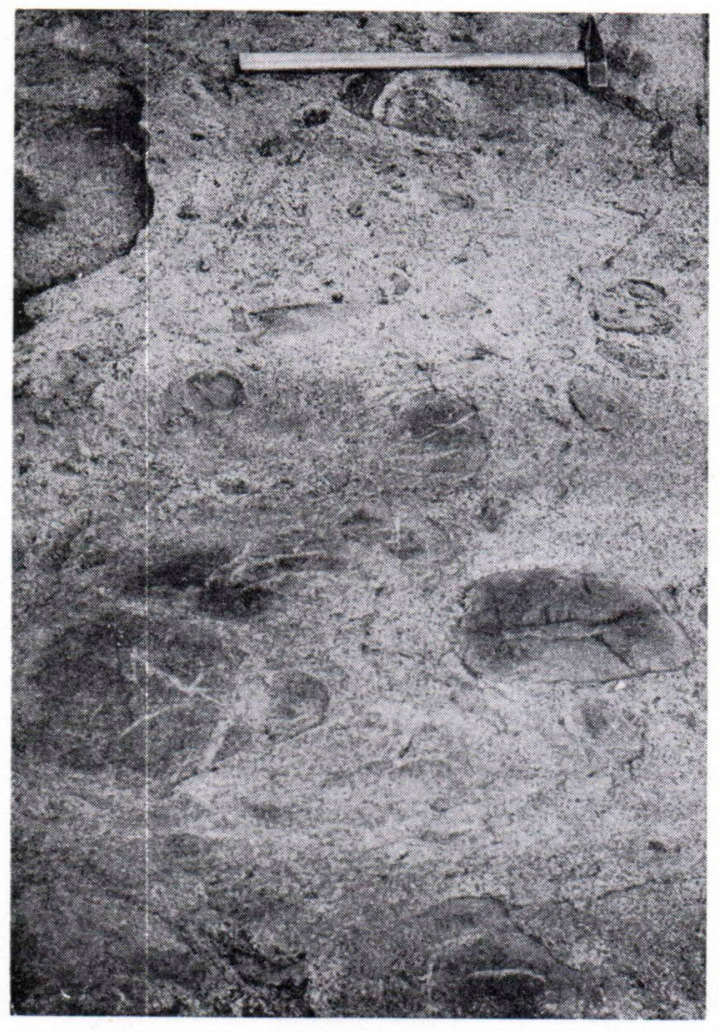

FIG. 26. Intrusive breccia: norite fragments in migmatite trondhjemite, Varpa-Toivo northern Haukivesi.

the most characteristic rock types in the northern Haukivesi area and occupies large tracts around the mangeritic intrusive bodies. It is a migmatic and tectonic mixture of intrusive and supracrustal rock material. In a trondhjemitic to quartzdioritic groundmass exhibiting flow folds and various turbulent structures, there are fragments of basic to ultrabasic intrusive rocks besides supracrustal material. The inclusions are angular to rounded and rotated in the migmatic matrix.

It is obvious that mica-gneiss fragments in the schollenmigmatites are primary, incompletely assimilated and broken up, competent mica gneiss layers and concretions. Likewise, the amphibolite fragments of the schollenmigmatites are amphibolitic intercalates of the biotite plagioclasegneiss complex broken in the process previously described. Further, the basic and ultar-basic fragments seem to be broken intrusive rock lenses and sills.

The schollenmigmatites are usually gneissose but in some places they have the appearance of unorientated intrusive breccia (Fig. 26). The schollenmigmatites grade into banded migmatites, supracrustal gneisses containing s-parallel trondhjemitic layers. Further away from the quartzdiorite, these become typical veined gneisses.

It has been possible to follow the grading of the homogeneous gneissic trondhjemite into migmatite trondhjemite in exposures. Often in the first phase the network of heterogeneous light-coloured trondhjemite brecciates gneissic trondhjemite (Fig. 27) in situ and gradually transforms it into a heterogeneous rock. Simultaneously, the complex is mobilized and attains a heterogeneously sheared texture.

A corresponding process has been witnessed in the alteration of veined gneiss into migmatite trondhjemite. At first, the veins of the gneiss are very abundant and "venitic» in character. In the next phase, one of the beds is mobilized but the more competent beds and e.g. concretions are still preserved. In the heterogeneous rock, partly assimilated breccia fragments from the former rocks can be observed (Fig. 28).

The mineral composition of the migmatite trondhjemite corresponds to that of the homo-

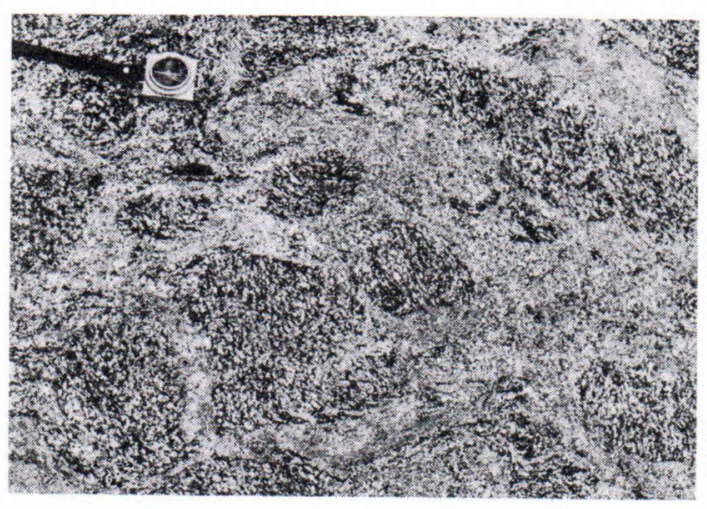

FIG. 27. Foliated homogeneous trondhjemite intruded by migmatite trondhjemite, Kangaslampi, Harjuranta. 


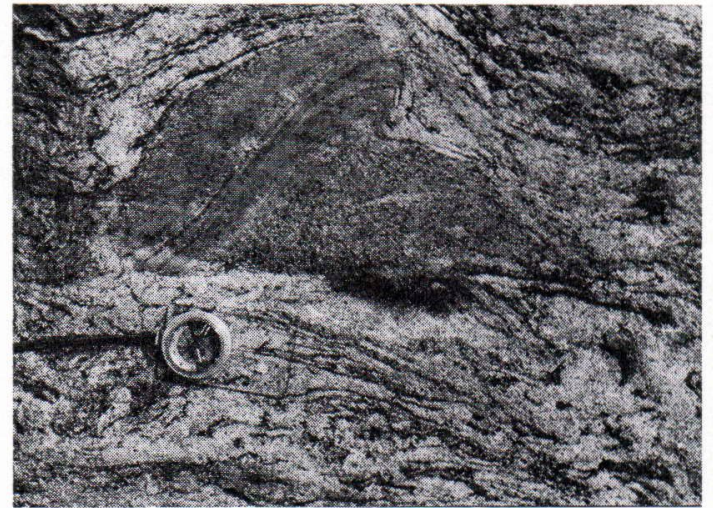

FIG. 28. Fragment consisting of mica gneiss and homogeneous trondhjemite in migmatite trondhjemite, Kangaslampi, Härmäniemi, Särkisaari.

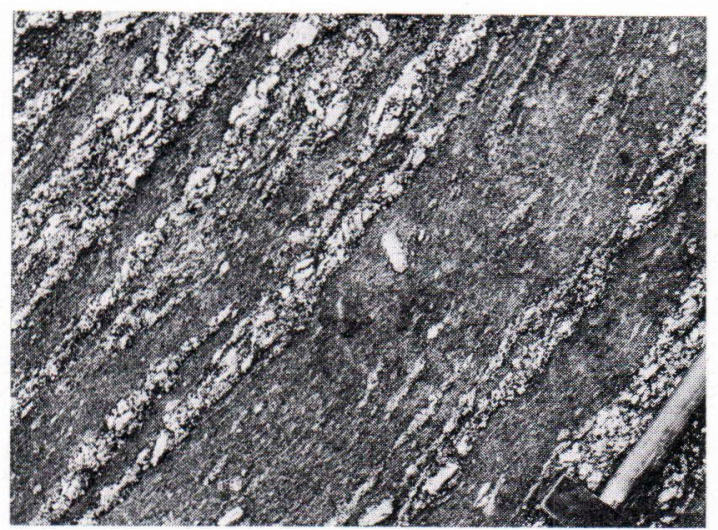

FIG. 29. Foliated pyroxene quartzdiorite migmatized by coarse-porphyric granite, Kangaslampi, Harjuranta. geneous trondhjemite and biotite-plagioclase gneiss.

The forementioned circumstances have led to the conclusion that the migmatite trondhjemite is palingenic and was formed anatectically during the emplacement of the mangeritic series from early-tectonic trondhjemites and the biotiteplagioclase-gneisses ( $c f$. e.g. garnet and cordierite content). It also obtained material by contamination from the mangeritic rocks ( $c f$. e.g. hypersthene and hornblende content). The sources of energy were probably vigorous movements and the thermal effect of the mangeritic series. Some of the source material seems to have originated straight from the most acid components of the mangeritic series.

\section{Migmatites produced by coarse-porphyric granodiorite}

It is typical of coarse-porphyric intrusive rocks that they form intrusive breccias with their environment, so that the discordant occurrence of coarse-porphyritic rocks in relation to other rocks is clear. On the other hand, the local conform migmatization with the strike of the host rock which can be observed in the contact zones strongly indicates synkinematic conditions during the intrusion phase. Also typical is the strong migmatic mixing of the contact zones, particularly with the intrusive rocks of the mangeritic series.

Metasomatism brought about by the coarseporphyritic rocks is common. Potash feldspar has grown as idiomorphic-porphyroblastic phenocrysts in all types of country rocks (Fig. 29) and in breccia fragments. The metasomatic potash feldspar phenocryst front frequently proceeds in a nebulous fashion. In many places, the forementioned processes have mixed up the rocks with each other so strongly that the contacts are very indictinct, e.g. those between the coarseporphyritic rocks and the rocks of the mangeritic series in the central Haukivesi area.

In the Joutsenmäki-Tolvanniemi area, the coarse-porphyritic granite to granodiorite occurs oval shaped around the gabbro and diorite intrusive of the mangeritic series. Here it is either locally homogeneous or brecciates gabbro and diorite or migmatizes cordierite gneisses and amphibolites.

Contamination of coarse-porphyric granite on the contact against pyroxene gabbro was observed in Harjuranta. Here very Fe-rich hornblende is encountered as a new mineral in porphyritic granite. If the contact rock is norite, Fe-rich pleochroic hypersthene also occurs. The biotite which was normally the major mineral of 
the porphyric granite decreases in abundance to become an accessory in place of hornblende and hypersthene. Plagioclase (An 37-42) is Caricher than is normal in porphyritic granites. However, potash feldspar is always the major mineral, whereas the abundance of quartz is considerably lower than in the primary coarse-porphyritic rocks.

\section{E. Granitization}

The potash-silica-metasomatic rocks of the central Haukivesi area have already been mentioned in the chapter on hybrid granodiorite. Secondary potash feldspar is also encountered in the northern Haukivesi area in the migmatite trondhjemites. It is typical that plagioclase is strongly sericitized in the potash feldsparbearing samples. There are no occurrences in this zone which are as distinct and concrete as those in the hybrid granodiorites of central Haukivesi. Thus, it has not been possible to depict this zone on the geological map. It is probable that the residual solutions of the coarseporphyritic rocks were the source of the potash in both cases.

IV ON THE METAMORPHOSIS OF THE SUPRACRUSTAL ROCKS

The supracrustal rocks of the Haukivesi area can be divided into three zones on the basis of their petrological characteristics: 1) The veined gneiss complex on the northern side of Haukivesi appears to represent normal and chiefly pelitic geosyncline sediments which recrystallized under the conditions of the almandine-amphibolite facies. 2) The mineral parageneses of the rocks in the NW-SE striking central zone of the Haukivesi area represent higher temperature and pressure conditions, corresponding to the granulite facies. In addition to hypersthene-bearing intrusive rocks, this zone is characterized by diopside amphibolites (sometimes hypersthenebearing) and hypersthene gneisses (paracharnoc- kites) in northern and central Haukivesi and by cordierite gneisses in the Parkumäki-Savonlinna zone. 3) The metaturbidite formation of Rantasalmi is a distinctly different block which has undergone a relatively low degree of metamorphism and represents the crystallization conditions of the almandine-amphibolite facies.

\section{ON THE PETROLOGICAL CHARACTERISTICS OF THE INTRUSIVE ROCKS}

\section{A. The early-tectonic trondhjemite series}

The major trondhjemite bodies are chiefly homogeneous indifferentiated intrusions. Only in exceptional cases do more basic differentiates and basic inclusions associate with them.

In Varparanta and $\mathrm{N}$ of Savonlinna basic inclusions have been encountered in the trondhjemite. It has not been possible in the field to establish the relationship between these basic xenoliths and the trondhjemites. There is no mutual grading and the basic rocks differ from the corresponding variants of the mangeritic series of the Haukivesi area being monotonous hornblende- and biotite bearing rocks.

Only hornblende-bearing variants are encountered as extensive trondhjemite differentiates. In these, the plagioclase has the highest An \% (An 40) encountered in trondhjemites.

It is easy on the basis of descriptions (A. Hietanen 1943, 1947, A. Huhma 1959) to find counterparts in the trondhjemites of S. W. Finland for the trondhjemites in the Haukivesi area. However, the An-content in the plagioclase seems to be the most significant petrographic difference. It is so high in the Haukivesi area (An 25-40) that most of the trondhjemites actually belong to the diorite-trondhjemite class.

\section{B. The mangeritic intrusives and the coarse- porphyric granodiorite as magmatic charnockites}

According to modern terminology, the term charnockite is applied much more extensively than allowed by the original definition by T. H. 
Holland (1893). Nowadays, there are acid, intermediary, basic and ultrabasic charnockites and it is understood that they are all magmatic rocks. In addition, the term paracharnockite is applied to charnockites which were produced by metamorphism from originally supracrustal rocks. It is characteristic of them that they only occur in Precambrian areas. They are most commonly intermediary in composition, whereas various pyroxene-amphibolites, hypersthenic and noritic rocks represent the basic and ultrabasic charnockites (F. J. Turner-J. Verhoogen, 1960).

In the wider sense of definition, the term magmatic charnockites can be implied to all the hypersthene-bearing intrusive rocks of the Haukivesi area, ie. rocks of the mangeritic series and coarse porphyritic rocks.

The more acid and intermediary types of charnockite are darker than usual due to the colour of the feldspars. Microscopically these are remarkably clear and fresh. The dry ironmagnesium mineral paragenesis: hypersthene, monoclinic pyroxene, brown hornblende and reddish brown biotite is extraordinary in that amphibole is most abundant in the ultrabasic types and hypersthene is common in the whole differentiation series right up to the pegmatitic segregations. Local inclined extinction and variation in the pleochroism in the hypersthene are not unusual.

In the pyroxene gabbros, hy pers the ne and monoclinic pyroxene have local lamellar exsolution structures. The uralitization of hypersthene seems to have led to brownish hornblende. The alteration product of monoclinic pyroxene is a blue-green hornblende. In addition to uralization, a yellowish serpentine-like mineral is encountered as an alteration product of hypersthene. According to A. Hietanen (1947), this mineral may be the first step in the alteration process of hypersthene to biotite. The third alteration product of hypersthene is cummingtonite which occurs abundantly e.g. in the norite micro-pegmatites.

$\mathrm{Plag}$ i oclase is always darker, greenish or brownish grey and translucent. According to I. Th. Rosenquist (1951), the dark colour is due to the ferri-iron pigment or possibly to the extremely fine sericite. However, plagioclase is only exceptionally sericitized. For the most part, it occurs as laths in gabbro-dioritic rocks and the texture approaches ophitic (orthocumulate type). An inverted and oscillating zoning of the phenocrysts is not uncommon in the gabbrodiorite variants which contain plagioclase phenocrysts most distinctly. According to S. S. Augustithis (1963), they are due to the variations in composition between the crystal phase and the magma melt which were possibly caused by the intense movements in the Haukivesi area. The plagioclase phenocrysts nearly always contain microscopic bubble-like elongated and oriented inclusions. The simultaneous twinning according to the three twinning laws (Albite, Karlsbad and Periklin) is typical of the phenocrysts.

In particular, brown hornblende and bright red-brown biotite are typical and differ in colour from those in the lower facies. The forementioned minerals are all typical waterpoor minerals of charnockites which indicate a high temperature of crystallization. According to H. Väyrynen (1954), the occurrence of hypersthene together with both feldspars requires a deficiency in water, otherwise biotite would be formed. This reaction has frequently taken place to some degree in the Haukivesi area, since biotite is often present in addition to hypersthene.

The mineral composition and the special features of the minerals in the rocks of the mangeritic series in the Haukivesi area correspond so well with those of the charnockites described from the West Uusimaa complex (K. Parras, 1958) and the Turku area that one is well justified in associating them with the charnockite group. The fact that charnockite rocks occur in the area both among intrusive and supracrustal rocks demonstrates that the local T-P conditions corresponded to the granulite facies. Thus it was possible for the same 
charnockite mineral composition to be attained from both the sedimentary and the magmatic side.

\section{GEOPHYSICAL MAPS}

\section{G. Gaál}

Two types of geophysical maps were available. The aeromagnetic maps of the Geological Survey of Finland on scales of 1:20000 and 1: 100000 were of invaluable aid during the mapping and drawing of the geological maps. The gravimetric map of the Finnish Geodetic Institute on a scale of 1:400 000 was employed in the overall structural interpretation of the area.

\section{AEROMAGNETIC MAP}

Since numerous magnetic anomalies were registered in the investigation area, the aeromagnetic maps (Map 1) give a revealing picture of the geological structures and also to some extent of the occurring rock types.

The most distinct anomalies are caused by diopside-amphibolites, which frequently contain pyrrhotite-bearing layers. Anomalies of similar intensity also occur in connection with sulphideand graphite-bearing schist intercalations in the Rantasalmi metaturbidites and the Savonlinna cordierite-gneisses. Magnetic anomalies are relatively sparse in the veined gneiss complex and are caused by sulphide-bearing graphite-gneiss layers.

Various intrusive rocks may be the source of the magnetic anomalies. Restricted parts of the mangeritic intrusions contain considerable amounts of magnetite. Also, the hybridic granodiorite is frequently magnetite-bearing and causes magnetic anomalies. The western margin of the coarse porphyric granodioritic Vuorisaari pluton is magnetic, which is explained by the occurrence of numerous amphibolite inclusions in the intrusive body.

\section{GRAVIMETRIC MAP}

It is well-known that the Haukivesi area is located on the gravimetric map of Finland in a strong positive anomaly, which at one point exceeds $35 \mathrm{mgal}$ (Fig. 30). Geological mapping revealed that large areas within the positive anomaly are composed of high-density charnockitic rocktypes. These rocks emerge clearly from the low-density environment which is composed of veined gneisses, metaturbidites and cordierite gneisses with an average density of $2.72-2.78$. By comparison with the value of the former rocks, the average density is in amphibolite 2.96 (4 determinations), in peridotite 3.14 (4 determinations), in gabbro 2.95 (95 determinations), in diorite 2.96 (12 determinations) and in quartz diorite 2.87 (20 determinations). Taking into account the size of the area occupied by the high-density rock types in the Haukivesi area, the high positive gravimetric anomaly can probably be explained on the basis of the occurrence of ultrabasic to intermediary igenous rocks. The presence of the latter will be explained in the chapter on structural analysis.

\section{TECTONICS \\ G. Gaál}

A rigorous structural analysis of the Haukivesi area yielded evidence of very complicated deformation patterns. The rocks of the area have been affected by polyphase folding, intrusions of igneous rocks, migmatization and fracturing. The complexity of the deformation mechanism has caused a great heterogenity of strain throughout the whole area. Statistic and analytic methods had to be applied in order to study the tectonic patterns properly. Tens of thousands of observations were made systematically over the area and various aspects of the collected data were analyzed. According to modern procedure the analysis has to be carried out in three major phases. In the first phase, the geometric analysis, the geometric properties of rocks and their 


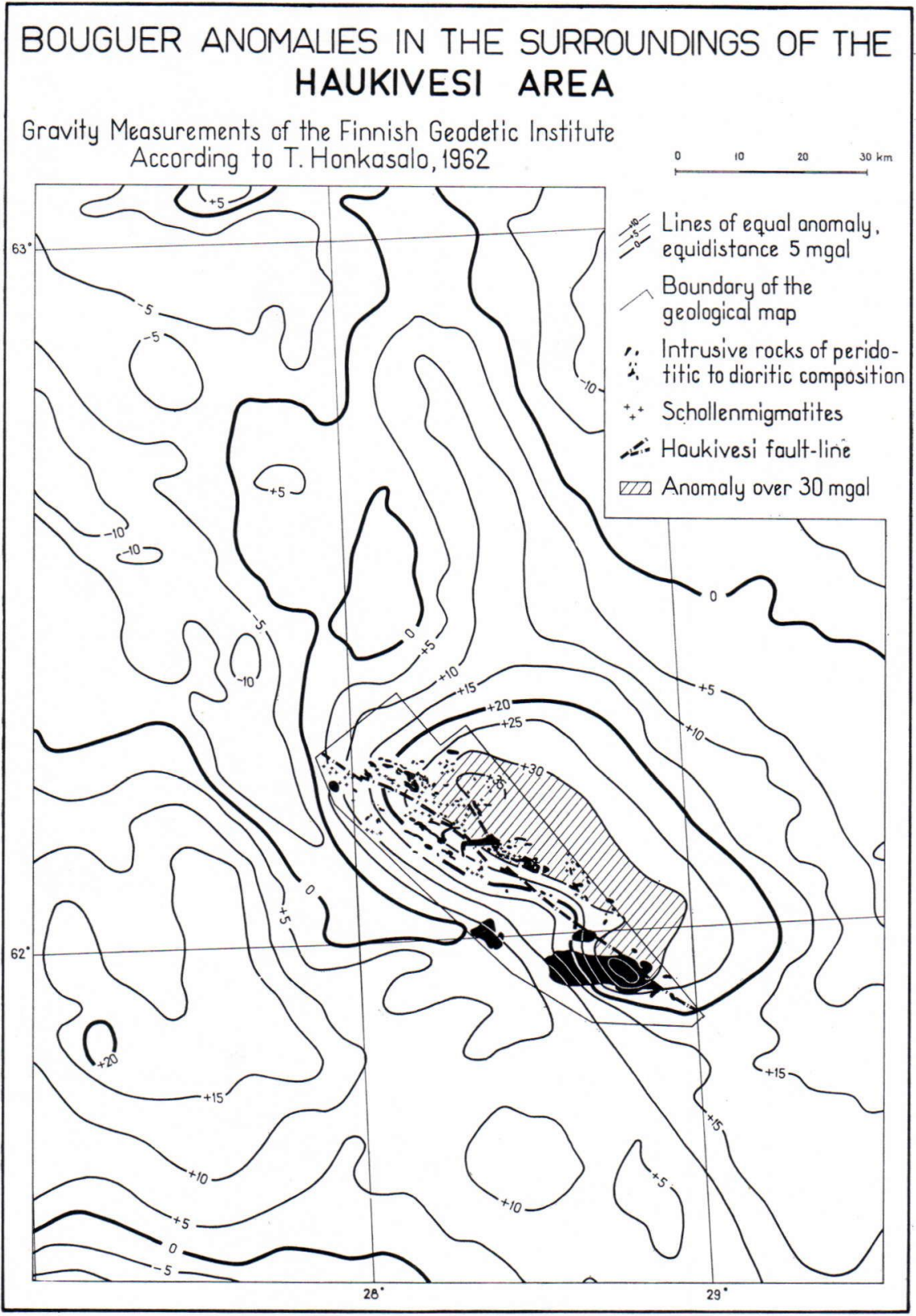

FIG. 30

general three-dimensional setting are studied and described. In the second phase, the kinematic analysis, deductions are made about past movements in the geologic formations in chronological succession. In the third phase, the dynamic analysis, conclusions are drawn con- cerning the stress fields which caused the deformation.

\section{GEOMETRIC ANALYSIS}

Because the statistical evaluation of the tectonic data was done by graphic methods, great empha- 
TABle 9

\begin{tabular}{|c|c|c|c|c|c|c|c|c|c|c|}
\hline & $\begin{array}{c}\text { Diagram } \\
\text { n:r }\end{array}$ & $\begin{array}{c}\text { Density } \\
\text { contour } \\
\max \end{array}$ & $\begin{array}{l}\text { Foli- } \\
\text { ation }\end{array}$ & $\begin{array}{l}\text { bedding } \\
\text { plane }\end{array}$ & $\begin{array}{l}\text { fold } \\
\text { axis }\end{array}$ & $\begin{array}{l}\text { line- } \\
\text { ation }\end{array}$ & $\beta 1$ & $\beta 2$ & $\pi \max 1$ & $\pi \max 2$ \\
\hline 1 & $\ldots \ldots \ldots$ & $8-$ & 170 & & 2 & 11 & & & $173 / 80$ & \\
\hline 2 & $\ldots \ldots$ & & 52 & & 3 & 11 & & & $197 / 82$ & \\
\hline 3 & $\ldots \ldots \ldots$ & $7-$ & 62 & & 4 & 18 & & & $015 / 75$ & \\
\hline 4 & $\ldots \ldots \ldots$ & $7-$ & 46 & & 1 & 1 & & & $030 / 82$ & \\
\hline 5 & $\ldots \ldots \ldots$ & $5-$ & 33 & & 3 & 1 & & & $056 / 38$ & $090 / 46$ \\
\hline 6 & $\ldots \ldots \ldots$ & $5-$ & 117 & & 2 & & & & $092 / 75$ & $072 / 37$ \\
\hline 7 & $\ldots \ldots \ldots$ & $8-$ & 192 & & 4 & 15 & $064 / 70$ & $064 / 60$ & $330 / 90$ & $035 / 73$ \\
\hline 8 & $\ldots \ldots \ldots$ & $5-$ & 64 & & 9 & 7 & $242 / 80$ & & & \\
\hline 9 & $\ldots \ldots \ldots$ & $7-$ & 105 & & 16 & 10 & $158 / 80$ & $90^{\circ}$ & $\sim 233 / 80$ & \\
\hline 10 & $\ldots \ldots \ldots$ & $5-$ & 87 & & 5 & 1 & $060 / 70$ & & & \\
\hline 11 & $\ldots \ldots \ldots$ & $5-$ & 36 & & 2 & & & & $036 / 75$ & \\
\hline 12 & $\ldots \ldots \ldots$ & $8-$ & 194 & & 28 & 11 & $298 / 70$ & & $210 / 90$ & \\
\hline 13 & $\ldots \ldots \ldots$ & $8-$ & 87 & & 8 & 1 & & & $176 / 80$ & \\
\hline 14 & $\ldots \ldots \ldots$ & $6-$ & 116 & & 17 & 1 & & & $160 / 90$ & \\
\hline 15 & $\ldots \ldots \ldots$ & $6-$ & 72 & & 8 & 5 & $055 / 75$ & & $053 / 75$ & \\
\hline 16 & $\ldots \ldots \ldots$ & $8-$ & 79 & & 18 & 5 & $054 / 75$ & & $039 / 75$ & $070 / 80$ \\
\hline 17 & $\ldots \ldots \ldots$ & $5-$ & 58 & & & 7 & $100 / 65$ & & & \\
\hline 18 & $\ldots \ldots \ldots$ & $5-$ & 89 & & 2 & 5 & $008 / 75$ & & $065 / 80$ & \\
\hline 19 & $\ldots \ldots \ldots$ & $8-$ & 189 & & 9 & 1 & $90^{\circ}$ & & & \\
\hline 20 & $\ldots \ldots \ldots$ & $8-$ & 149 & 3 & 3 & 4 & $042 / 80$ & & $092 / 80$ & \\
\hline 21 & $\ldots \ldots$ & $8-$ & 134 & & 15 & 4 & $110 / 75$ & & & \\
\hline 22 & $\ldots \ldots \ldots$ & $5-$ & 217 & & 18 & 12 & $126 / 70$ & & & \\
\hline 23 & $\ldots \ldots \ldots$ & $6-$ & 47 & & 16 & & & & & \\
\hline 24 & $\ldots \ldots \ldots$ & $5-$ & 24 & 52 & 8 & 8 & $273 / 15$ & $093 / 10$ & $359 / 74$ & \\
\hline 25 & $\ldots \ldots \ldots$ & $7-$ & 214 & & 21 & & $320 / 75$ & & $022 / 80$ & \\
\hline 26 & $\ldots \ldots \ldots$ & $6-$ & 94 & & & & $317 / 60$ & & $250 / 75$ & \\
\hline 27 & $\ldots \ldots \ldots$ & $6-$ & 94 & & & & $286 / 10$ & $106 / 35$ & & \\
\hline 28 & $\ldots \ldots \ldots$ & $4-$ & 25 & & 8 & & $104 / 20$ & & & \\
\hline 29 & $\ldots \ldots \ldots$ & $4-$ & 54 & & 13 & & $306 / 20$ & $321 / 45$ & $026 / 67$ & \\
\hline 30 & $\ldots \ldots \ldots$ & $6-$ & 74 & & 33 & & & & $024 / 85$ & \\
\hline 31 & $\ldots \ldots \ldots$ & $7-$ & 351 & & 33 & 2 & $348 / 60$ & $324 / 40$ & $034 / 67$ & \\
\hline 32 & $\ldots \ldots \ldots$ & $10-$ & 229 & & 3 & & $088 / 44$ & $054 / 58$ & $035 / 60$ & \\
\hline 33 & $\ldots \ldots \ldots$ & $7-$ & 81 & & 12 & & $323 / 40$ & & $029 / 64$ & \\
\hline 34 & $\ldots \ldots \ldots$ & $10-$ & 42 & 22 & 20 & 2 & & & $035 / 78$ & \\
\hline 35 & $\ldots \ldots \ldots$ & $8-$ & 101 & 1 & 10 & & & & $025 / 75$ & \\
\hline 36 & $\ldots \ldots \ldots$ & $4-$ & 31 & & 8 & & $116 / 10$ & & & \\
\hline 37 & $\ldots \ldots \ldots$ & $10-$ & 192 & 1 & 1 & & $101 / 60$ & & $023 / 82$ & \\
\hline 38 & $\ldots \ldots \ldots$ & $11-$ & 202 & 10 & 14 & & $115 / 70$ & & $058 / 78$ & $162 / 75$ \\
\hline 39 & $\ldots \ldots \ldots$ & $5-$ & 17 & 9 & 9 & 2 & $168 / 50$ & & $083 / 85$ & \\
\hline 40 & $\ldots \ldots \ldots$ & $7-$ & 89 & 15 & 13 & 7 & $351 / 40$ & & $261 / 90$ & \\
\hline 41 & $\ldots \ldots \ldots$ & $7-$ & 135 & 47 & 13 & 6 & $042 / 50$ & & $116 / 80$ & \\
\hline 42 & $\ldots \ldots \ldots$ & $5-$ & 35 & 82 & 16 & 3 & $280 / 00$ & & & \\
\hline 43 & $\ldots \ldots \ldots$ & $8-$ & 60 & 121 & 21 & & $302 / 45$ & & $025 / 82$ & \\
\hline 44 & $\ldots \ldots \ldots$ & $7-$ & 70 & & & & $318 / 65$ & & $000 / 70$ & \\
\hline 45 & $\ldots \ldots$ & $6-$ & 55 & 3 & 6 & & & & & \\
\hline 46 & $\ldots \ldots \ldots$ & $6-$ & 69 & 54 & 9 & 6 & $306 / 60$ & & $036 / 90$ & \\
\hline 47 & $\ldots \ldots \ldots$ & $7-$ & 97 & 31 & 15 & 5 & $327 / 60$ & & $048 / 85$ & \\
\hline 48 & $\ldots \ldots \ldots$ & $7-$ & 64 & 19 & 14 & 9 & & & $007 / 80$ & \\
\hline 49 & $\ldots \ldots \ldots$ & $8-$ & 35 & 101 & 4 & 9 & $092 / 30$ & & $009 / 80$ & \\
\hline 50 & $\ldots \ldots \ldots$ & $5-$ & 40 & 82 & 5 & 8 & $067 / 80$ & & $350 / 85$ & \\
\hline 51 & $\ldots \ldots \ldots$ & -8 & 42 & 87 & 13 & & $106 / 10$ & $082 / 30$ & $019 / 78$ & \\
\hline 52 & $\ldots \ldots \ldots$ & $7-$ & 209 & & 6 & 2 & & & $000 / 90$ & \\
\hline 53 & $\ldots \ldots \ldots$ & $5-$ & 84 & & 2 & 33 & $302 / 70$ & & & \\
\hline 54 & $\ldots \ldots \ldots$ & $8-$ & 252 & 17 & 9 & 5 & $070 / 55$ & & $028 / 63$ & \\
\hline 55 & $\ldots \ldots \ldots$ & $5-$ & 73 & & 3 & & & & & \\
\hline 56 & $\ldots \ldots \ldots$ & $5-$ & 43 & 18 & 30 & 11 & $107 / 40$ & & $023 / 80$ & \\
\hline 57 & $\ldots \ldots \ldots$ & $5-$ & 60 & & 5 & 4 & & & & \\
\hline 58 & $\ldots \ldots \ldots$ & $8-$ & 108 & 26 & 15 & 12 & $292 / 35$ & $292 / 55$ & $018 / 85$ & \\
\hline 59 & $\ldots \ldots \ldots$ & $5-$ & 26 & 22 & 9 & 3 & $107 / 50$ & & & \\
\hline 60 & $\ldots \ldots \ldots$ & $5-$ & 19 & & 3 & 1 & & & $051 / 75$ & \\
\hline 61 & $\ldots \ldots \ldots$ & $6-$ & 96 & & & 11 & $334 / 50$ & & $028 / 62$ & \\
\hline 62 & $\ldots \ldots \ldots$ & $5-$ & 8 & 45 & 21 & & $305 / 00$ & & $034 / 80$ & $034 / 20$ \\
\hline
\end{tabular}


TABLE 9. (Continuing)

\begin{tabular}{|c|c|c|c|c|c|c|c|c|c|c|}
\hline & $\begin{array}{c}\text { Diagram } \\
\text { n:r }\end{array}$ & $\begin{array}{c}\text { Density } \\
\text { contour } \\
\max \end{array}$ & $\begin{array}{l}\text { Foli- } \\
\text { ation }\end{array}$ & $\begin{array}{l}\text { bedding } \\
\text { plane }\end{array}$ & $\begin{array}{l}\text { fold } \\
\text { axis }\end{array}$ & $\begin{array}{l}\text { line- } \\
\text { ation }\end{array}$ & $\beta 1$ & $\beta 2$ & $\pi \max 1$ & $\pi \max 2$ \\
\hline 63 & $\ldots \ldots \ldots$ & $5-$ & 4 & 65 & 8 & 1 & $103 / 35$ & & & \\
\hline 64 & $\ldots \ldots \ldots$ & $8-$ & 55 & & 13 & 1 & $084 / 75$ & & $068 / 76$ & \\
\hline 65 & $\ldots \ldots \ldots$ & $8-$ & 56 & 61 & 18 & 25 & $320 / 46$ & & $353 / 50$ & \\
\hline 66 & $\ldots \ldots \ldots$ & $5-$ & 83 & & 24 & 10 & $330 / 70$ & & & \\
\hline 67 & $\ldots \ldots \ldots$ & $7-$ & 84 & & 6 & & & & & \\
\hline 68 & $\ldots \ldots \ldots$ & $5-$ & 40 & & 9 & 6 & & & $035 / 72$ & \\
\hline 69 & $\ldots \ldots \ldots$ & $5-$ & 73 & & 6 & 2 & & & $203 / 80$ & \\
\hline 70 & $\ldots \ldots \ldots$ & $9-$ & 218 & & 16 & 3 & $346 / 70$ & & $051 / 78$ & \\
\hline 71 & $\ldots \ldots$ & $9-$ & 149 & & 20 & & $335 / 68$ & & $038 / 78$ & \\
\hline 72 & $\ldots \ldots \ldots$ & $10-$ & 546 & & 52 & 58 & $342 / 70$ & & $335 / 70$ & \\
\hline 73 & $\ldots \ldots \ldots$ & $5-$ & 74 & & 12 & 16 & 90 & & & \\
\hline 74 & $\ldots \ldots \ldots$ & $5-$ & 93 & & 8 & 32 & $120 / 55$ & & $039 / 82$ & $070 / 65$ \\
\hline 75 & $\ldots \ldots \ldots$ & $5-$ & 99 & & 20 & 6 & $070 / 60$ & & טगנים & $070 / 03$ \\
\hline 76 & $\ldots \ldots$ & $8-$ & 121 & 3 & & 14 & $340 / 35$ & & $299 / 43$ & \\
\hline 77 & $\ldots \ldots \ldots$ & $8-$ & 77 & 43 & 13 & 37 & $049 / 55$ & & $007 / 62$ & \\
\hline 78 & $\ldots \ldots$ & $8-$ & 228 & & 7 & 36 & & & $007 / 80$ & \\
\hline 79 & $\ldots \ldots \ldots$ & $10-$ & 169 & & 22 & 4 & & & $018 / 85$ & \\
\hline 80 & $\ldots \ldots \ldots$ & $8-$ & 96 & & 16 & 9 & & & $341 / 78$ & \\
\hline 82 & $\ldots \ldots \ldots$ & $7-$ & 114 & & 1 & 17 & $004 / 60$ & & $339 / 62$ & \\
\hline 83 & $\ldots \ldots \ldots$ & $10-$ & 195 & 28 & 34 & 133 & $293 / 45$ & & $350 / 60$ & \\
\hline 84 & $\ldots \ldots \ldots$ & $10-$ & 124 & 34 & 22 & 84 & $040 / 55$ & & & \\
\hline 85 & $\ldots \ldots \ldots$ & $8-$ & 187 & 33 & 23 & 96 & $022 / 35$ & $075 / 45$ & $326 / 52$ & \\
\hline 86 & $\ldots \ldots$ & $10-$ & 140 & 70 & 20 & 80 & $306 / 35$ & & $023 / 70$ & \\
\hline 87 & $\ldots \ldots$ & 9 & 174 & 4 & 24 & 114 & $331 / 50$ & & & \\
\hline 88 & $\ldots \ldots \ldots$ & $5-$ & 43 & 45 & 2 & 15 & $010 / 40$ & & $347 / 42$ & \\
\hline 89 & $\ldots \ldots \ldots$ & $5-$ & 65 & & 6 & 4 & $344 / 40$ & & $022 / 47$ & \\
\hline 90 & $\ldots \ldots$ & $7-$ & 41 & 2 & & 20 & $301 / 48$ & & $312 / 50$ & \\
\hline 91 & $\ldots \ldots \ldots$ & $6-$ & 67 & 23 & 6 & 23 & $331 / 50$ & & $303 / 48$ & \\
\hline 92 & $\ldots \ldots \ldots$ & $10-$ & 545 & 31 & 43 & 62 & $024 / 70$ & & $350 / 72$ & $015 / 72$ \\
\hline 93 & $\ldots \ldots \ldots$ & $8-$ & 194 & 3 & 8 & 26 & & & $352 / 90$ & \\
\hline 94 & $\ldots \ldots \ldots$ & $6-$ & 66 & 10 & & 10 & & & $343 / 86$ & \\
\hline 95 & $\ldots \ldots \ldots$ & $12-$ & 369 & 82 & 23 & 161 & 90 & & & \\
\hline 96 & $\ldots \ldots \ldots$ & $6-$ & 46 & 7 & & 28 & 90 & & & \\
\hline 97 & $\ldots \ldots \ldots$ & $8-$ & 163 & 1 & 9 & 3 & & & $352 / 90$ & \\
\hline 98 & $\ldots \ldots$ & $10-$ & 272 & 4 & 10 & 28 & & & $212 / 90$ & \\
\hline 99 & $\ldots \ldots \ldots$ & $6-$ & 67 & 6 & 3 & 17 & $120 / 44$ & & $207 / 85$ & \\
\hline 100 & $\ldots \ldots$ & $8-$ & 171 & 9 & & 47 & & & $347 / 90$ & \\
\hline 101 & $\ldots \ldots \ldots$ & $6-$ & 205 & 15 & 4 & 27 & $117 / 75$ & & & \\
\hline 102 & $\ldots \ldots \ldots$ & $5-$ & 44 & 8 & & 9 & & & $044 / 72$ & \\
\hline 103 & $\ldots \ldots \ldots$ & $5-$ & 43 & 14 & & 38 & $074 / 60$ & & & \\
\hline 104 & $\ldots \ldots \ldots$ & $8-$ & 68 & 15 & 10 & 11 & & & $027 / 85$ & \\
\hline 105 & $\ldots \ldots \ldots$ & $8-$ & 236 & & 14 & 9 & & & $015 / 77$ & \\
\hline 106 & $\ldots \ldots \ldots$ & $4-$ & 27 & 10 & 5 & 6 & $074 / 30$ & & $354 / 76$ & \\
\hline 107 & $\ldots \ldots \ldots$ & $4-$ & 38 & 20 & 3 & 7 & $292 / 40$ & $292 / 25$ & $006 / 72$ & \\
\hline 108 & $\ldots \ldots \ldots$ & $8-$ & 116 & 21 & 2 & 19 & $040 / 60$ & & $358 / 67$ & \\
\hline 109 & $\ldots \ldots \ldots$ & $4-$ & 26 & 30 & 6 & 1 & $274 / 55$ & & $354 / 83$ & \\
\hline 110 & $\ldots \ldots \ldots$ & $3-$ & 37 & & 6 & & $322 / 60$ & & & \\
\hline 111 & $\ldots \ldots \ldots$ & $3-$ & 38 & & 3 & 1 & & & $020 / 85$ & \\
\hline 112 & $\ldots \ldots \ldots$ & 5 & 85 & & 5 & 4 & $275 / 63$ & & $202 / 82$ & \\
\hline 113 & $\ldots \ldots \ldots$ & $5-$ & 58 & 26 & 5 & 4 & $279 / 25$ & $279 / 05$ & $356 / 65$ & \\
\hline 114 & $\ldots \ldots \ldots$ & 7 & 184 & & 9 & 4 & $098 / 45$ & & $008 / 90$ & \\
\hline 115 & $\ldots \ldots \ldots$ & $7-$ & 234 & & 2 & 3 & & & $041 / 80$ & \\
\hline 116 & $\ldots \ldots \ldots$ & $6-$ & 80 & & 1 & 1 & & & $213 / 80$ & \\
\hline 117 & $\ldots \ldots \ldots$ & $6-$ & 105 & & 1 & 5 & & & $182 / 60$ & \\
\hline 118 & $\ldots \ldots \ldots$ & $5-$ & 92 & & 8 & 10 & $255 / 70$ & & & \\
\hline 119 & $\ldots \ldots \ldots$ & $3-$ & 64 & & & 3 & $098 / 20$ & $130 / 40$ & & \\
\hline 120 & $\ldots \ldots \ldots$ & $8-$ & 177 & & 2 & 4 & $030 / 65$ & & $068 / 74$ & $042 / 65$ \\
\hline 121 & $\ldots \ldots \ldots$ & $4-$ & 55 & 1 & 7 & 5 & $220 / 40$ & $220 / 60$ & $170 / 52$ & \\
\hline 122 & $\ldots \ldots \ldots$ & $4-$ & 38 & & & 4 & $138 / 10$ & & & \\
\hline 123 & $\ldots \ldots \ldots$ & $3-$ & 24 & & 2 & 8 & $074 / 15$ & & & \\
\hline 124 & $\ldots \ldots \ldots$ & $3-$ & 20 & & 1 & 4 & & & & \\
\hline 125 & $\ldots \ldots \ldots$ & $4-$ & 50 & & 3 & 2 & & & & \\
\hline 126 & $\ldots \ldots \ldots$ & $5-$ & 92 & & 3 & 6 & 90 & & & \\
\hline
\end{tabular}


sis was placed on the evidence of maps, drawings and diagrams in the presentation of results. The data were compiled in various ways in order to arrive at an objective interpretation.

The bulk of the measurements was plotted on a Schmidt net. The equal area projections and the diagram areas were connected to a tectonic map of the planar structures (Map 7). The primary aim of this map was to indicate the homoaxial areas. However, most of the diagrams represent them only approximately and many of them not at all. This is because the severity of deformation in the Haukivesi area prevents the conditions of homoaxiality from being fulfilled, even locally. As a result of the heterogenity of the deformation, the criteria for homiaxiality had to be extended in many cases during the compiling of the diagrams. Table 9 shows the analytical results of the equal area diagrams of map 7. In cases where a significant maximum of linear structures or a clear girdle of planar structures is obtained, a constructed fold axis $\beta_{1}$ was determined. In some cases of fold interference, another constructed fold axis $\beta_{2}$ could be presumed. The planar structures show clear and strong maxima in most of the diagrams. The strongest are depicted in Table 9 as single poles $\pi_{\max 1}$. In interference folding, additional maxima may occur, the strongest of which are determined as $\pi_{\max 2}$. In most of the cases, $\pi_{\max }$ can be called an isoclinal maxi$\mathrm{mu} \mathrm{m}$, since it represents the orientation of the limbs of the isoclinal folds.

\section{A. Bedding and foliation}

Fig. 31 gives an idea of the changes in the strike and dip of the planar structures. In spite of the great variation, there are clear maxima of orientation. The main maximum of the planar structures in the Haukivesi area is $025 / 80$. Another less significant maximum is $355 / 80$. These values were obtained from a synopsis diagram of all the $\pi_{\max 1}$ of table 9 .

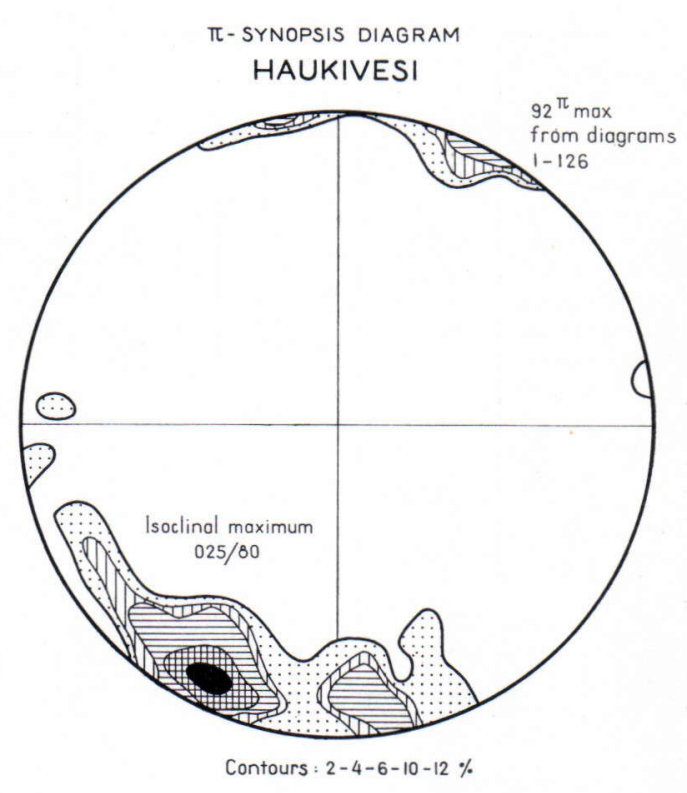

FIG. 31. Planar structures of the Haukivesi area on a synopsis diagram.

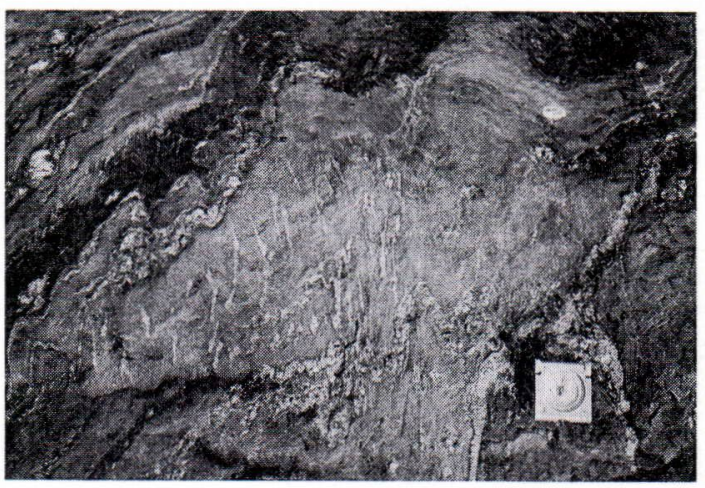

FIG. 32. Veined gneiss in which trondhjemitic veins develop parallel to the axial plane in folded biotite plagioclase gneiss, Ahvensalmi.

In the veined g neis s complex of the northern Haukivesi area, bedding can be recognized in only a few places. The predominant planar structure is gneissic foliation with subparallel trondhjemitic or granite veins. Axial plane schistosity was observed in only one place and in this example granitic veins develop parallel to the axial plane cleavage (Fig. 32). 


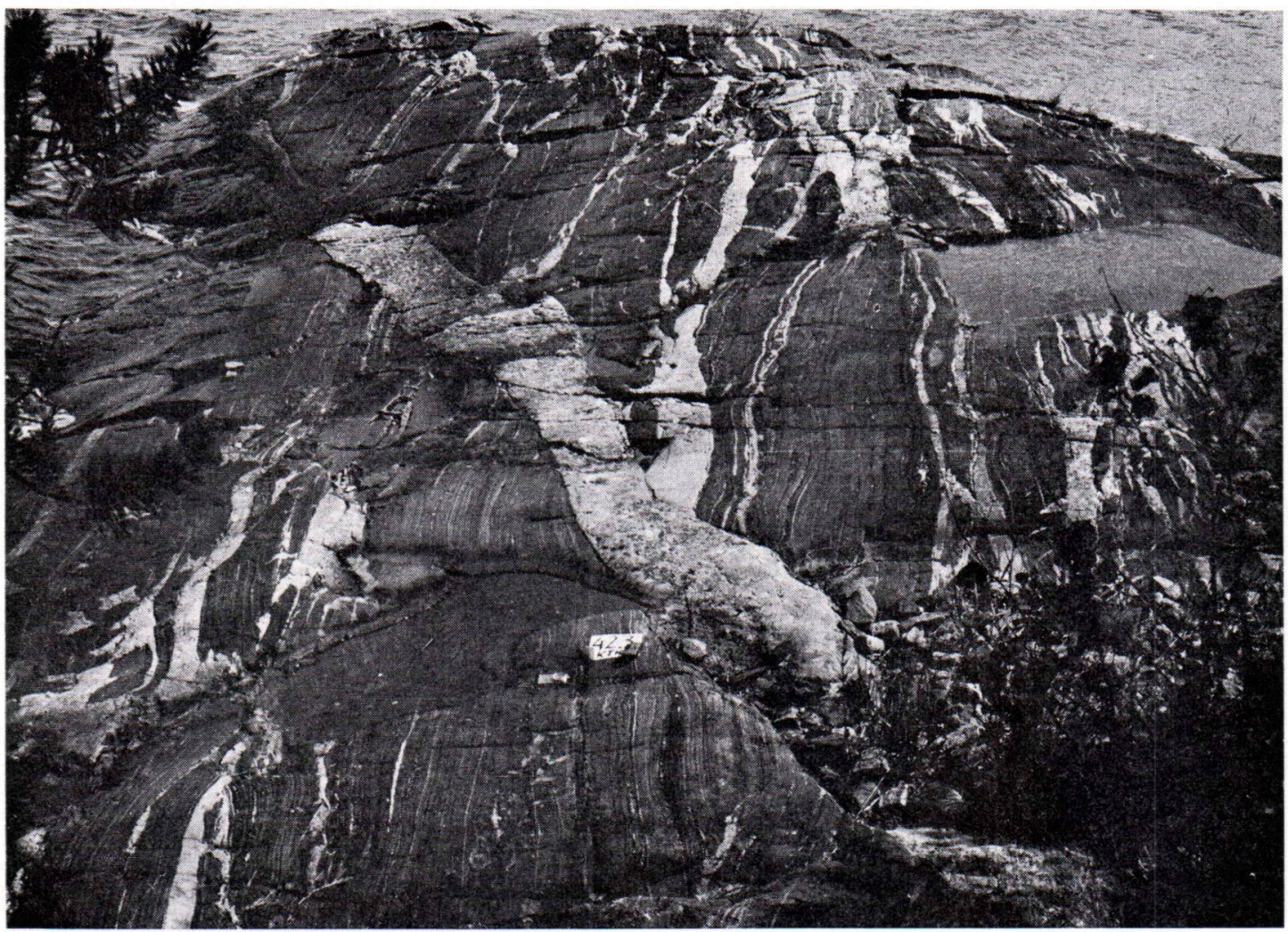

FIG. 33. Bedded diopside amphibolite with conform trondhjemite veins and a cross-cutting pegmatite vein, central Haukivesi.

In the a m ph i o lite complex, the bedding can usually be determined by the interlayering of diopside- and hornblende-rich layers (Fig. 33) and by intercalations of marble and quartzite beds (Fig. 34). The foliation can be bedding plane schistosity or axial plane cleavage, with the former, however, predominating.

In the metaturbidite complex of the southern Haukivesi area, bedding can frequently be identified and the foliation is axial plane cleavage (Fig. 35).

\section{B. Fold axis and lineations}

The great significance of linear structures in the interpretation of geological structures in

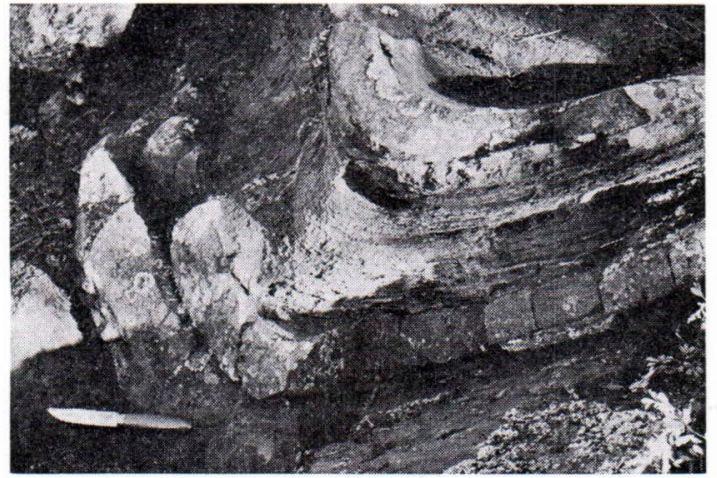

Frg. 34. Interbedding of diopside amphibolite, quartzite and carbonate, Eevasaari, central Haukivesi. 


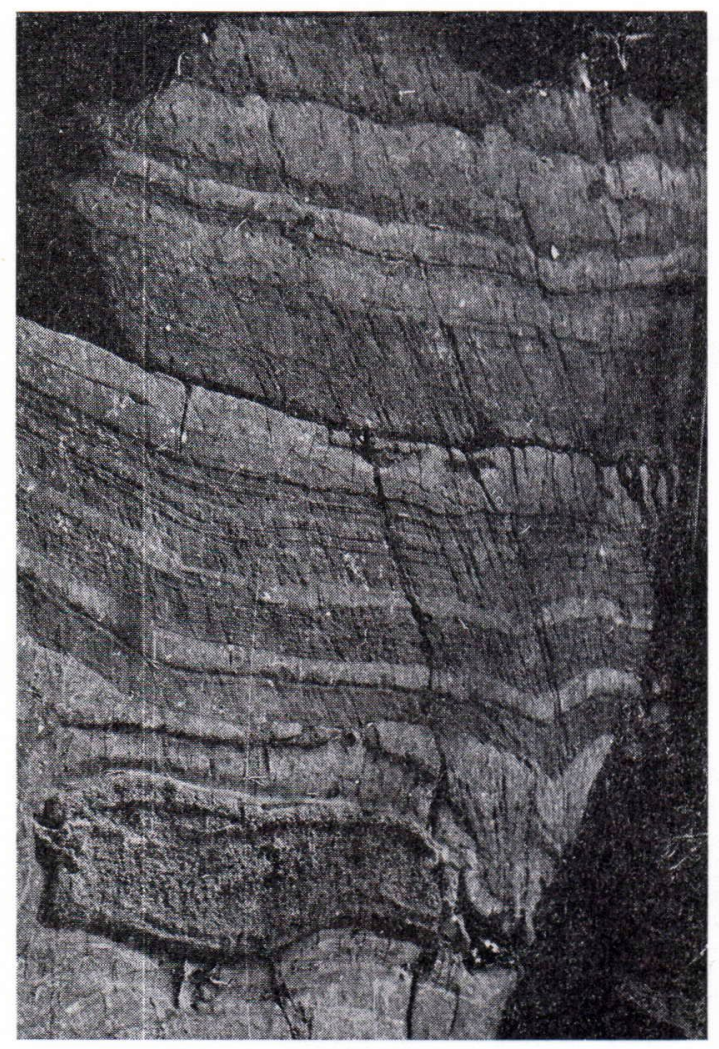

FIG. 35. Rantasalmi metaturbidite with graded bedding, concretion and axialplane cleavage, SE of Rantasalmi. order to obtain a complete three-dimensional picture is generally recognized. For this reason, special attention was paid to the investigation of fold axes and lineation.

During the field work three types of linear structure were recorded: lineation, minor fold axes and fold axes. Lineation was denoted as the parallel orientation of rock components such as minerals, quartz veins, pebbles and concretions. The term, minor fold axis, was applied to folds with a half wavelength less than one metre. Folds bigger than this were recorded as fold axes. Since no regional difference could be established between the two types, both minor fold axes and fold axes were treated together on maps and diagrams as fold axes in general.

\section{Linear structures on the polar equal area net}

In order to study the direction of plunge of the linear elements, most of the lineations and fold axes measured in the field were plotted on a polar equal area net. On Map 2, the diagrams of 65 sub-areas show the direction of plunge of 2620 linear structures. The diagrams are divided into $10^{\circ}$ sectors. The data are weighted: linear

\section{FOLD AXIS AND LINEATIONS IN THE HAUKIVESI AREA}
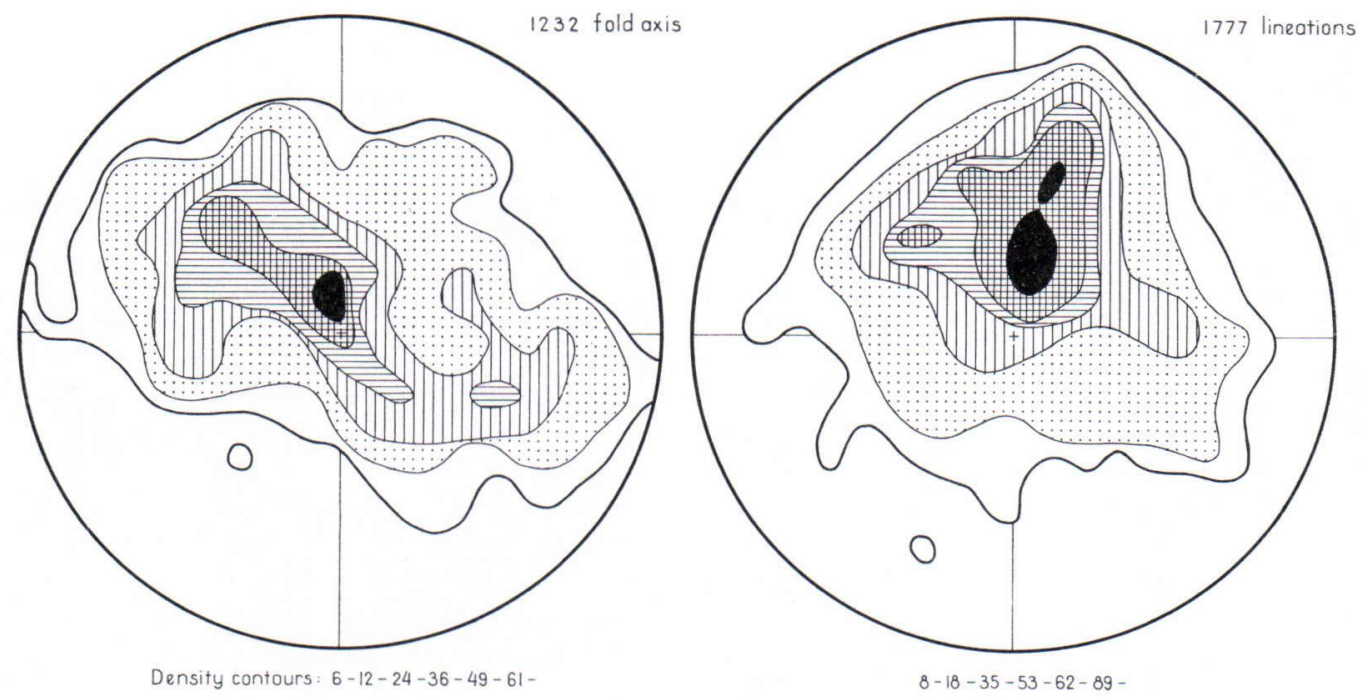

FIG. 36, 
elements with a plunge of less than $50^{\circ}$ have full value, whereas those with more than $50^{\circ}$ only half value. The sector which contains the greatest amount of linear elements in each diagram is drawn up to the outer circle of the diagram. The length of the other sectors is calculated accordingly.

\section{Linear structures on the Schmidt net}

On the Schmidt net, 1777 lineations and 1232 fold axes were compiled in separate diagrams (Fig. 36). The fold axes were mainly controlled by the plane of the isoclinal maximum $025 / 80$. The lineations show a strong maximum on plane $105 / 90$ which is approximately perpendicular to the general strike. This difference between fold axes and lineations derives from measurements collected chiefly in the southern part of the area, from diagram areas 83, 84, 85 and 86 (Fig. 48). Here the lineations represent tectonic coordinate axis a and the fold axis tectonic coordinate axis b. However, in the other parts of the Haukivesi area, the plunge of the lineations and the fold axes seems to be more or less the same. In the schollenmigmatites and banded migmatites, a rather exceptional phenomen was observed in connection with a turbulent type of deformation, whereby linear structures tend to rotate on a plane parallel to the isoclinal maximum (Fig. 37).

\section{Dip of linear structures}

In order to study statistically the magnitude of the plunge of the linear structures a distribution diagram was prepared (Fig. 38). This diagram indicates that $40 \%$ of all the linear structures in the Haukivesi area have a plunge between 40 and $60^{\circ}$ and that a clear maximum occurs around $45^{\circ}$. A gentle dip from 0 to $20^{\circ}$ comprises only $5 \%$ of the total field observations. Also vertical linear elements with a plunge from 80 to $90^{\circ}$ are relatively rare, embracing only $5 \%$ of the total number of measurements.

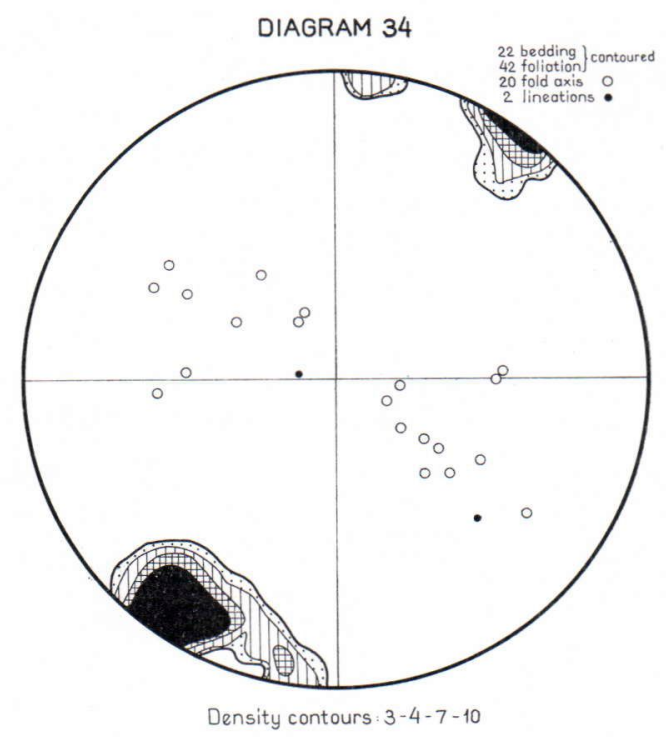

FIG. 37. "Rotation» of linear structure in schollenmigmatite, Heinävesi, Rantasalmi.

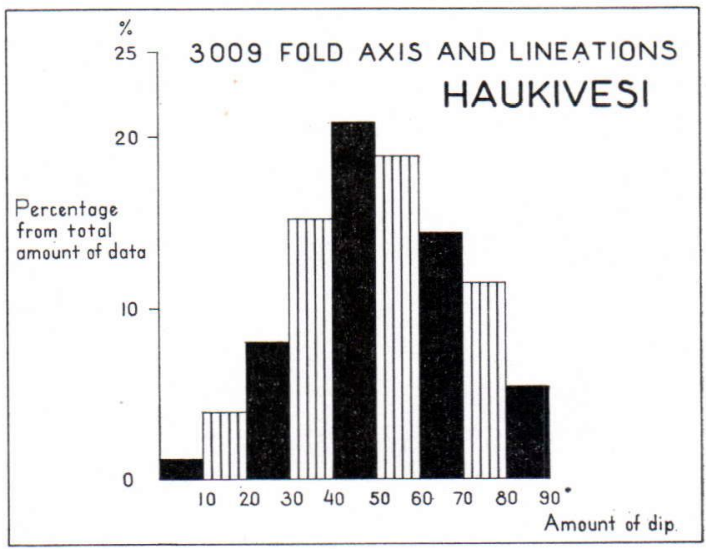

FIG. 38. Magnitude of plunge of the linear structures in distribution diagram.

\section{Linear structures on a contoured map}

All the information about the linear structures has been summarized on a contoured map (Map 3), which clearly shows the complexity of the strain in the Haukivesi area. The remarkable variation in the direction and magnitude of the plunge can be explained by the refolding of earlier folds in several subsequent or partly 
simultaneous phases. The general strike of the linear structures is WNW-ESE. In the northern part of the area, cross fold zones, N-S striking culmination zones, can be recognized, whereas there are only a few depression zones and these are usually rather local. In many places, the linear structures seem to be twisted in the direction of strike. This phenomen has been termed a $\mathrm{x}$ i a 1 t o r s i o n in the present study. Most obvious is the axial torsion south of Linnasaari: in diagram areas $51,54,56,59$ and 63 the plunge is towards $\mathrm{E}-\mathrm{SE}$ whereas in diagram areas 53, 58, 61 and 65 towards NW (Map 7).

\section{Folding}

Deformation by folding and by fracturing are kept separate in the analysis. This is an artificial distinction, since in the Haukivesi area the same tectonic forces have simultaneously or subsequently caused both the fracturing and the folding.

In the investigation area the competence difference is of primary importance in the formation patterns on local and a regional scale. According to general experience, the more competent is a rock the more regularly it deforms. Therefore, a c o m petence sequence in the Haukivesi area can be established on the basis of the degree of regularity in the deformation patterns. The sequence progresses from competent to incompetent: Rantasalmi-metaturbidites, diopside-amphibolite, cordierite-gneiss, veined gneiss, migmatites and synkinematic intrusions. The increasing grade of migmatization causes increasing incompetency.

Distinctions must be made between folding on an outcrop scale (mesoscopic scale) and on a regional scale (macroscopic scale). Since good exposures in the investigation area exhibit many fold structures, the authors' information concerning folding on an outcrop scale is of empiric nature, whereas, the deductions as to folding on a regional scale are compulsorily somewhat hypothetic.

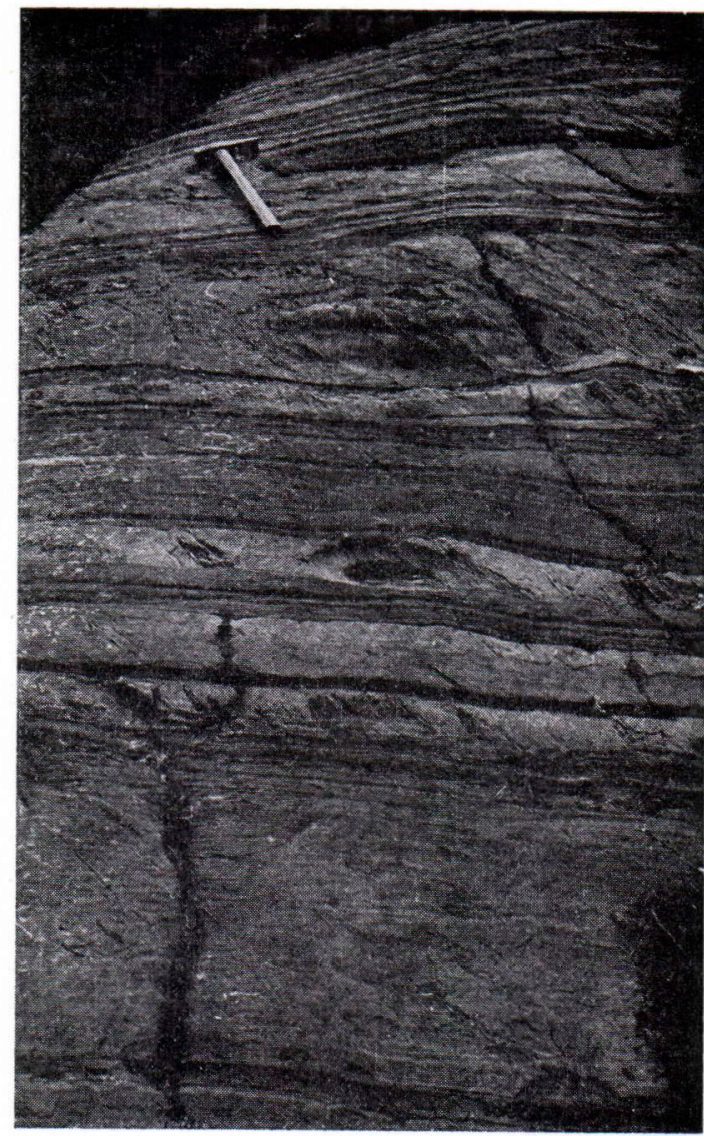

FIG. 39. Axialplane cleavage refraction in Rantasalmi metaturbidite, SE of Rantasalmi.

\section{Folding on outcrop scale}

The metaturbidites of Rantasalmi have flexural flow folding with axial plane cleavage. Axialplane cleavage refraction is a very common phenomenon (Fig. 39). The bottom direction of the folds, as determined from the bedding-cleavage relation, corresponds with the direction of the sedimentation bottom.

The diopside-amphibolites exhibit isoclinal or nearly isoclinal slip folds (Fig. 40). Flexural flow folds with axial plane cleavage occur in a few places, but bedding plane schistosity seems to be the most common. The competent calcsilicate and quartzite layers in the amphibolite are usually boudinated, whereas the incompetent 


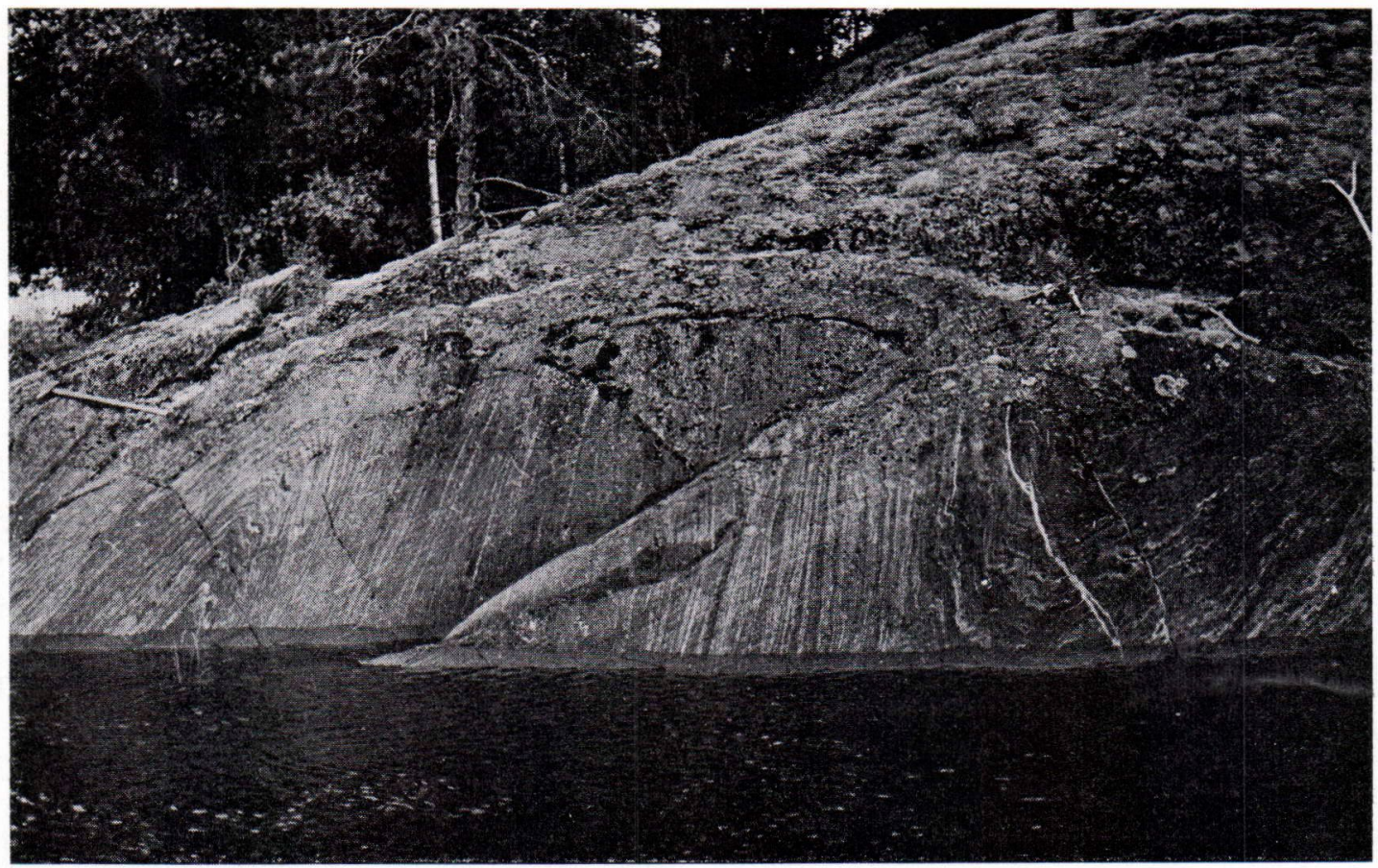

FrG. 40. Isoclinal folding in diopside amphibolite, Rantasalmi, Teemassaari.

marble intercalations are disharmonically folded (Fig. 41).

The cordierite-gneisses deform in a less migmatized state in the same way as the Rantasalmi metarurbidites by regular flexural flow folds. However, with increasing granitization their fold patterns become irregular and disharmonic. Calc-silicate and psammitic intercalations in the cordierite gneiss are commonly boudinated (Fig. 13).

The veined gneisses of the northern Haukivesi area deformed in a rather plastic state and exhibit disharmonic, often almost turbulent folding. Characteristic of them is the intense minor folding of the incompetent, strongly migmatized layers (Fig. 42) and the ptygmatic folded veins.

The fold style of the migmatites is generally completely disharmonic flexural folding. The layers of the competent paleosom break up and the whole rock may be folded and contorted like paste (Figs. 43, 44). Schollenmigmatite

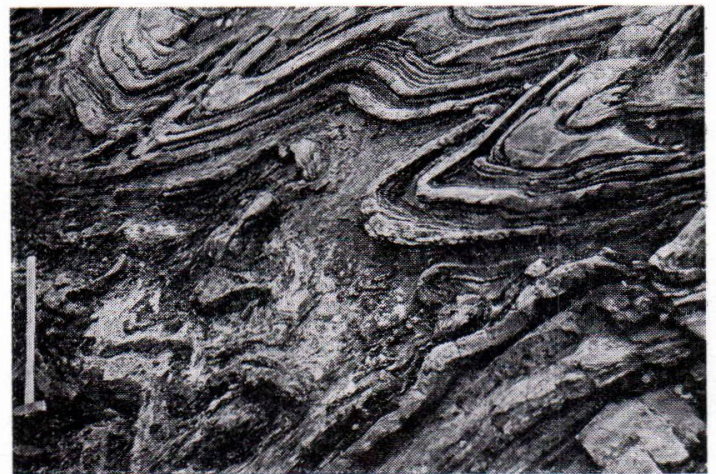

FIG. 41. Disharmonic folding in marble intercalations in diopside amphibolite, Eevasaari, central Haukivesi.

structures develop in extremely strongly deformed zones (Fig. 45).

\section{Folding on regional scale}

The most common types of large folds in the Haukivesi area are tightly pressed isoclinal folds 


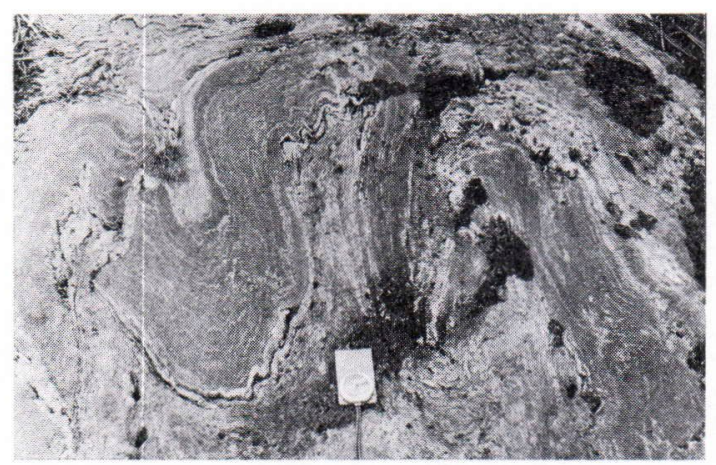

FIG. 42. Plastic folding in veined gneiss, Ruissaari, Rantasalmi.

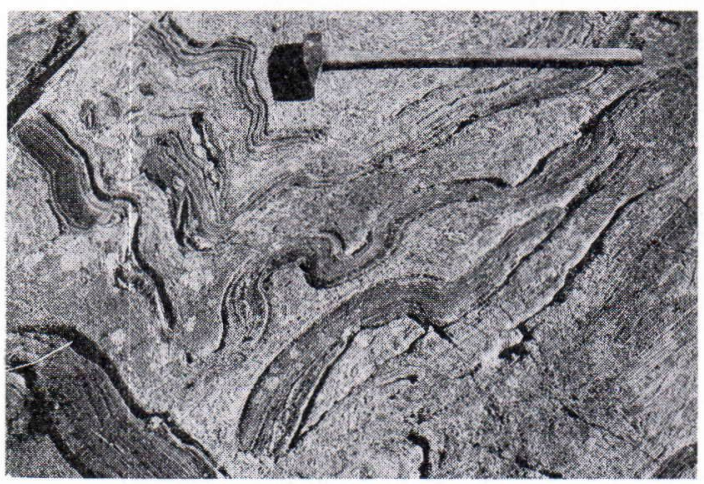

FIG. 43. Disharmonic folding of brecciated amphibolite layers in migmatite trondhjemite, Rantasalmi, Heinävesi.

with steep axial planes (Fig. 45 A). According to statistical analysis, the average dip of the axial planes of these isoclinal folds is $025 / 80-355 / 80$ (Fig. 31). Reviewing this WNW-to W-striking main fold set in detail, it can be seen that the axial planes of the folds in the northern part of the area are nearly vertical, in the central part 10 to $30^{\circ}$ and in the southern part, around Savonlinna, 20 to $60^{\circ}$ overturned towards S. The main fold set is influenced by two other sets of large folds with SW and N-S strikes.

The SW trending fold set predominates south of the line Kallislahti-Sääminki. The rather abrupt change of strike along this line is marked by a conglomerate horizon. The $\mathrm{N}-\mathrm{S}$ striking fold set developed in cross folds of the northern and central Haukivesi area. Besides these fold

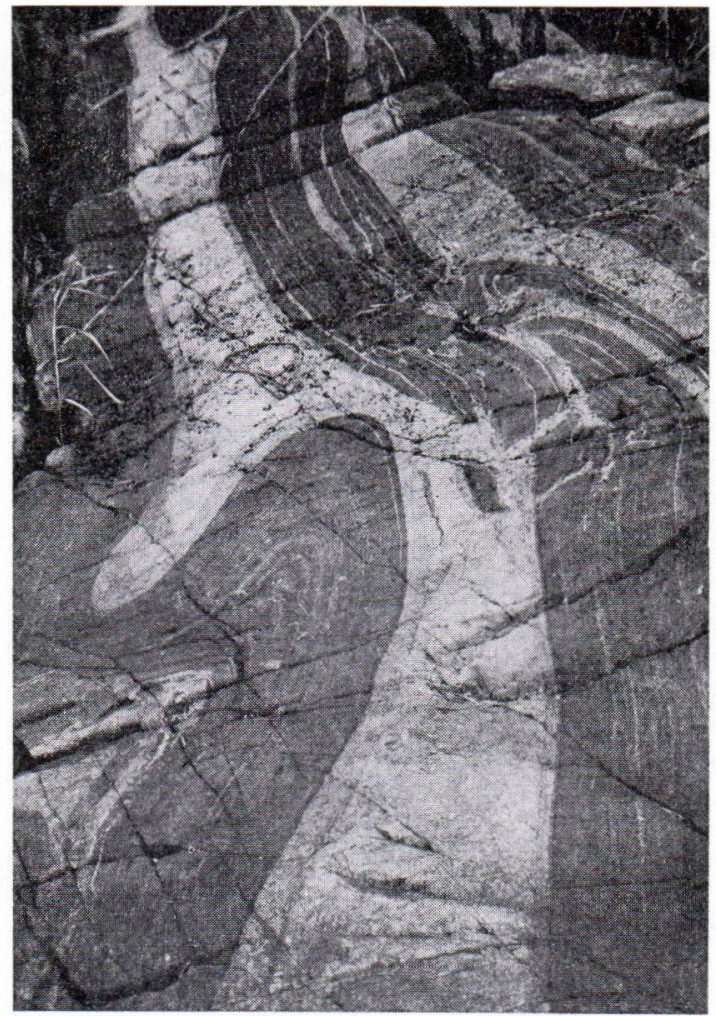

Frg. 44. Décollement fold in diopside amphibolite trondhjemite banded migmatite, central Haukivesi.

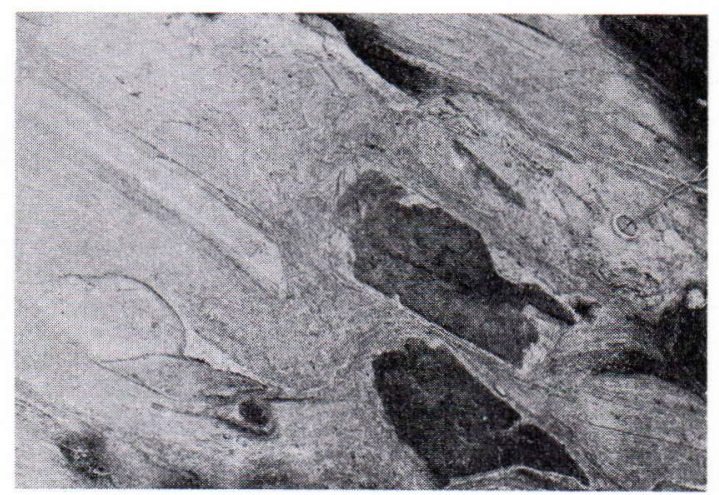

FIG. 45. Schollenmigmatite, Rantasalmi, Teemassaari.

sets, there is a conspicuous NW striking zone of vertical folds connected with a fracture system parallel to their axial plane, the Haukivesi fracture zone. The latter are probably the youngest fold structures of the area. 


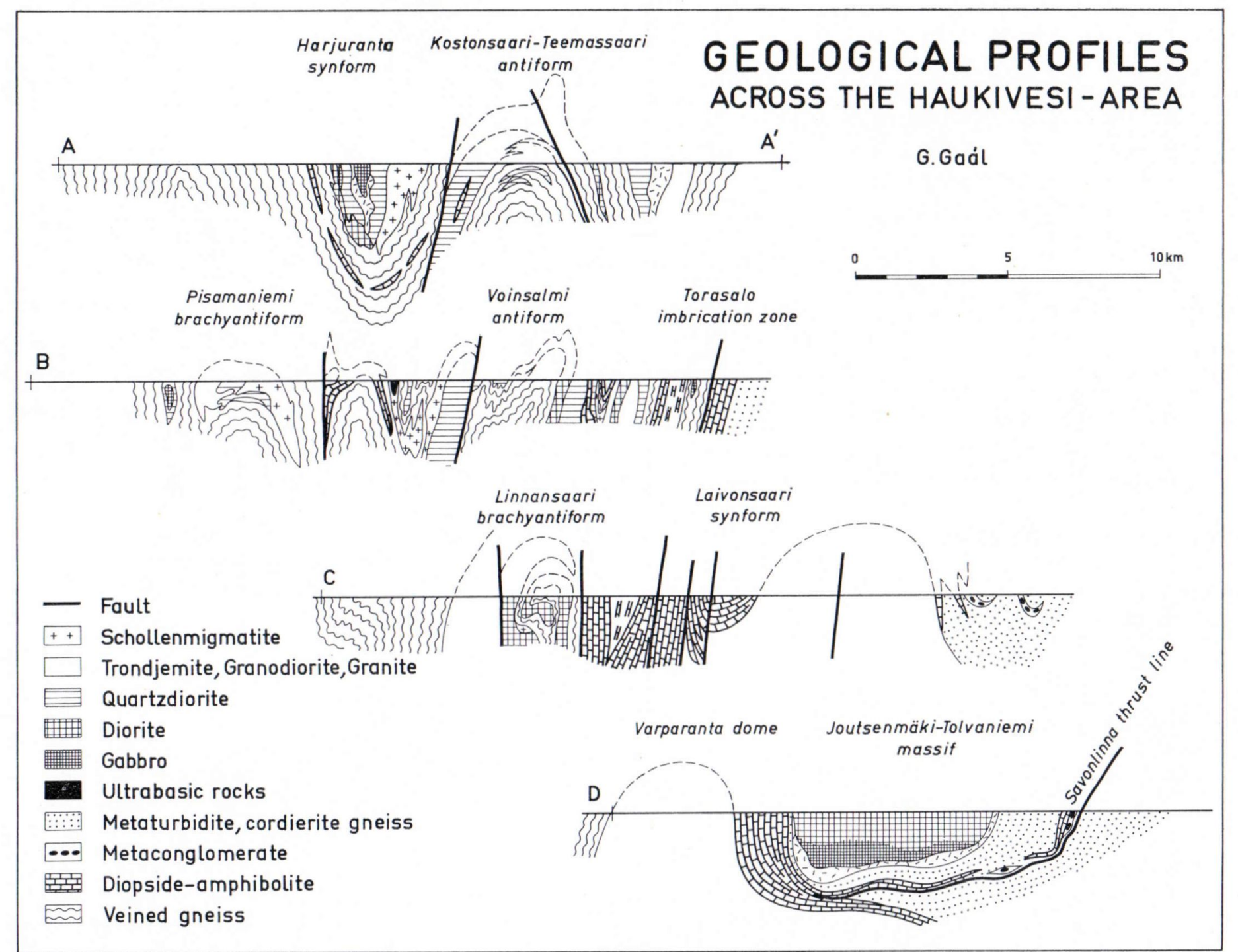

FIG. 45 A. 
Folding affected the Haukivesi area in several phases. In some of them, the early phases of folding are entirely overprinted because of the severity of the subsequent deformation phases. Only in those places where mappable stratigraphic horizons occur could relics of older fold generations be deciphered with some probability. In younger folding, the structures of the previous deformation phases and the sheets of the syntectonic intrusives are confolded.

In the following section, the most important fold structures are described, proceeding from the northern part of the area southwards. The main structures are illustrated in the structural interpretation of map 4.

The monotonous veined gneiss terrain in the northern part of the mapping area changes in the vicinity of Lake Haukivesi where the supracrustal rocks are invaded by several series of intrusives connected by characteristic structural forms. The northernmost intrusive complex, which consists of trondhjemite, quartzdiorite, diorite and pegmatitic granite, is exposed at the core of the oval-shaped Pis a manie mi-brach y a nt if or m. The next, considerably larger intrusive stock was emplaced along the axis of the $\mathrm{Harjuranta}$ s ynform. The northern limb of this large fold has an average dip of $80^{\circ}$ towards $\mathrm{S}-\mathrm{SW}$ (Diagrams 1, 2, 8 and 9 in Table 9). Its southern limb dips $75-80^{\circ}$ in the opposite direction. The eastern end of the Harjuranta synform is bent around a vertical axis in a Z-shaped fold, i.e. the vertical fold of Härmäniemi.

South of the Harjuranta synform, the broad open structure of the $\mathrm{K}$ os t on s a r i-T e e$\mathrm{m}$ as s a ri a $\mathrm{n}$ if or $\mathrm{m}$ rises from beneath. This large fold consists mainly of pyroxenebearing veined gneisses, a layer of diopsideamphibolite and thick sheets of quartzdiorite. The NW part of the anfiform changes over towards the SW into an open synform, which accomodates diorite, hornblende-gabbro and hornblendite in its core. The SE part of the antiform, is cut by an E-W striking vertical fracture and, at the same time, narrows into a more tightly folded SE-plunging antiform, which is finally cut off by the Torasalo imbrication zone. The narrowing and bending of the Kostonsaari-Teemassaari-antiform is due to the superimposing influence of the same $\mathrm{Z}$ shaped vertical fold which deformed the Harjuranta synform. There are tectonically interesting small $\mathrm{Ni}-\mathrm{Cu}$ bearing peridotite intrusions within this system, which were emplaced near the crossing of the axial planes of the antiform and the vertical fold with the E-W striking fracture.

The Voinsalmi antiform is probably the continuation of the same antiform zone. The core of this antiform is cordierite- and garnet-bearing veined gneiss (kinzigite) overlaid by a migmatitic horizon containing hybridic diorite with brecciated amphibolite, gabbro fragments and schollenmigmatites. Upwards, the migmatitic horizon passes over into a homogeneous quartz-diorite.

The Torasalo imbrication zone is the product of a rather complicated interaction between isoclinal folding, high angle reverse faulting, intrusions and migmatization. The axial planes of the folds together with the faults dip $70-80^{\circ}$ towards N-NW. Veined gneisses, pyroxene-gneisses, diopside-amphibolite, various migmatites and divers intrusives are mixed up in this zone. Due to their competency, the diopsideamphibolite layers are astonishingly well-preserved in this strongly altered environment. Some fold structures can be studied by following the amphibolite layers. A dome structure with a mantle of diopside-amphibolite and a core of gneissose hyb+idic granodiorite was mapped around V e tä mäs a a r i (Diagrams 107, 108 and 110). In Torasalo, a similar diopsideamphibolite forms a synform with a core of hybridic granodio+ite. Westwards, this very synform changes unrecognizably into an antiform. The reverse faults, which are so significant tectonically, can only be presumed in the Torasalo imbrication zone. They must have acted subparallel to the isoclinal folds in the manner of 
an imbrication but subsequent irtrusions and migmatization make it impossible to map particular fault lines. The suspicion awakes in this subarea that slices of the old basement haves sheared up from the depths along the faults of the imbrication zone. Some hybridic gneiss granites encountered are reminiscent of the gneiss granites of the Prekarelian basement around Kuopio.

In the $\mathrm{R}$ antas a 1 o s y $\mathrm{n}$ form (Figs. 46 and 47), mapping revealed folding in four phases. In the first phase, the diopside-amphibolite was folded together with veined gneiss in a recumbent anticline facing south. In the second phase, this structure was refolded in a synform and, in the third phase, it was again c coss-folded into a depression. In the fourth phase, during the intrusion of the Vuorisaari pluton, the earlier structures were bent around a vertical axis.

The oblong oval-shaped structure of the $\mathrm{L}$ i nnansa ri brachyantiform comes to the surface east of the Rantasalo synform. It is an isoclinal fold with a dip of $60-80^{\circ}$ towards $\mathrm{N}-\mathrm{NNW}$, which plunges on the western side towards WNW (Diagram 43) and on the eastern towards E (Diagram 54). The internal structure of the brachyantiform indicates that diorite had intruded during an earlier folding phase.

In an antiform zone in Varparanta, two ovalshaped zones known as the $\mathrm{Varparanta}$ $\mathrm{d}$ o $\mathrm{mes}$ have been described by B. Saltikoff (1964). The essential material of the domes is trondhjemite, which has conform contacts against diopside-amphibolite in the south and against veined gneisses in the north. The trondhjemite contains minor gabbro and diorite bodies besides inclusions of the surrounding supracrustal rocks. The structural relations in the western Varparanta dome are indistinct because of the scarcity of exposures, but, on the basis of field data, a NNE-SSW elongated dome structure can be assumed with some probability. The eastern Varparanta dome is a clear WNW-ESE elongated dome structure marked by a concentric strike of foliation around the centre of the structure. The dip of foliation is flat in the centre and steepens towards the margins. The veined gneisses north of the antiform exhibit a vertical dip. The diopside-amphibolites in the south have an average dip of $007 / 80$ (Diagram 78). Information about the linear structures in the Varparanta domes is rather fragmentary. On the western side of the eastern dome, where a sufficient amount of data could be collected, linear elements plunge towards $\mathrm{W}-\mathrm{NW}$, gradually steepening from the centre towards the margin. W and $\mathrm{S}$ of the dome a narrow zone of steep plunge was registered (Map 3).

West of the Varparanta domes, the trondhjemite again emerges beneath the diopside-amphibolite in the NNW striking $\mathrm{Hevossalo}$ b r a c h y a n t if or m, where the trondhjemite forms typical banded migmatites together with diopside amphibolite. The Hevossalo brachyantiform is an open fold, its eastern limb dipping $70^{\circ}$ towards WSW and its western limb having an average dip of 299/43 (Diagram 76). It is truncated in the north by the Haukivesi fault line and in the south by a minor fracture. South of this minor fracture, a WNW-ESE striking fold in the trondhjemite could be considered a continuation of the Hevossalo antiform. However, this cannot be verified because of the scarcity of exposures.

The trondhjemite and banded migmatites of the western limb of the Hevossalo brachyantiform gradually bend into the $\mathrm{L}$ a i v a $\mathrm{ns}$ a a $\mathrm{r}$ $\mathrm{s} y \mathrm{nform}$. The core of this synform is a nonmigmatitic diopside-amphibolite. The axis of the synform is deformed due to the effect of the vertical fold of the southern Haukivesi area (see diagram area 76 and cf. 340/35 and 320/46 in diagram area 65). Northwards, the Laivansaari synform borders on the Haukivesi fracture zone and is cut by a fault parallel to its axial plane. Its northern limb is steep to vertical, which may also be caused by the faulting. Its southern limb dips $40^{\circ}$ towards NE.

As seen on the geological map, the diopside amphibolite $\mathrm{E}$ and SE of the Hevossalo brachyantiform is bent into a V-shaped structure, the 


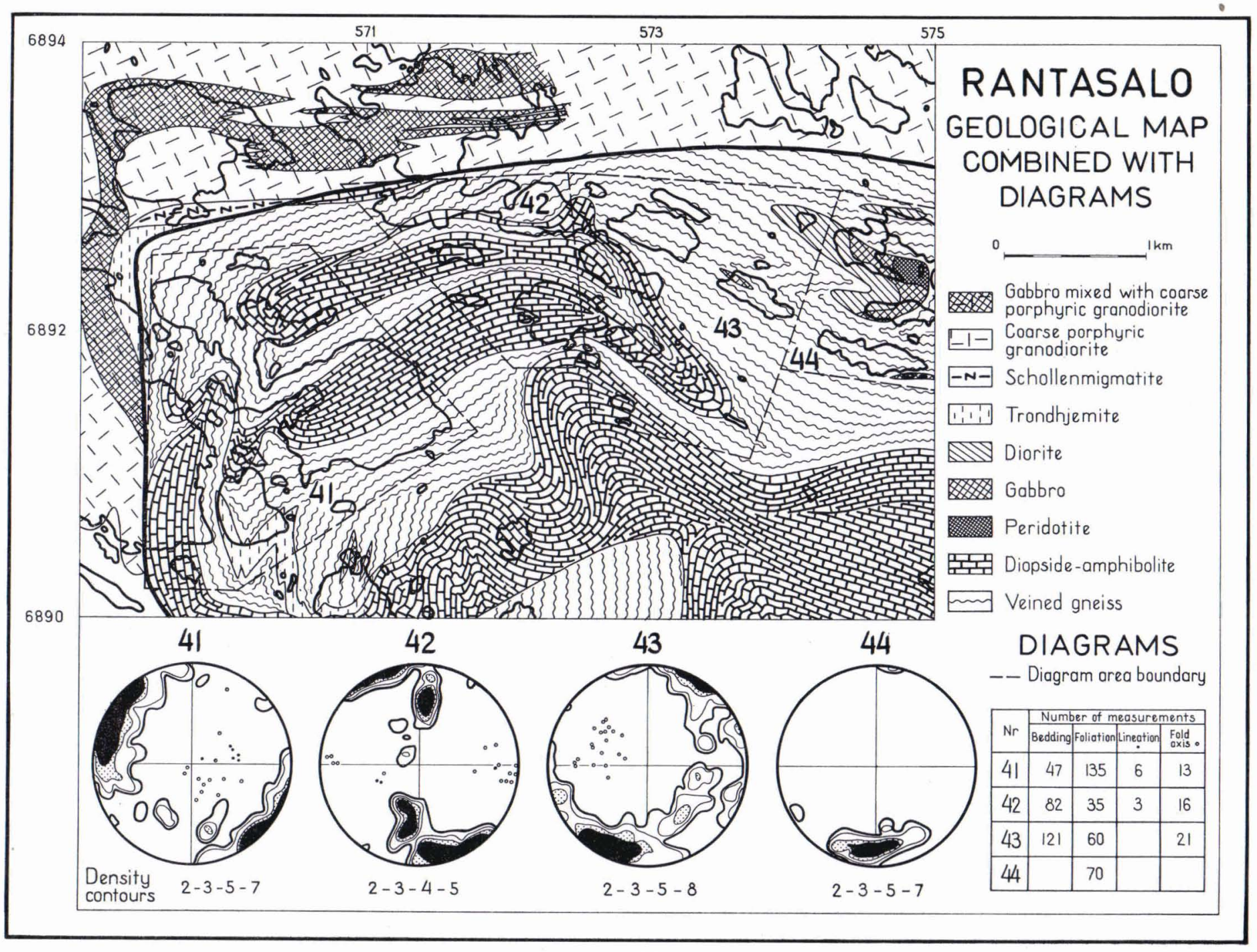




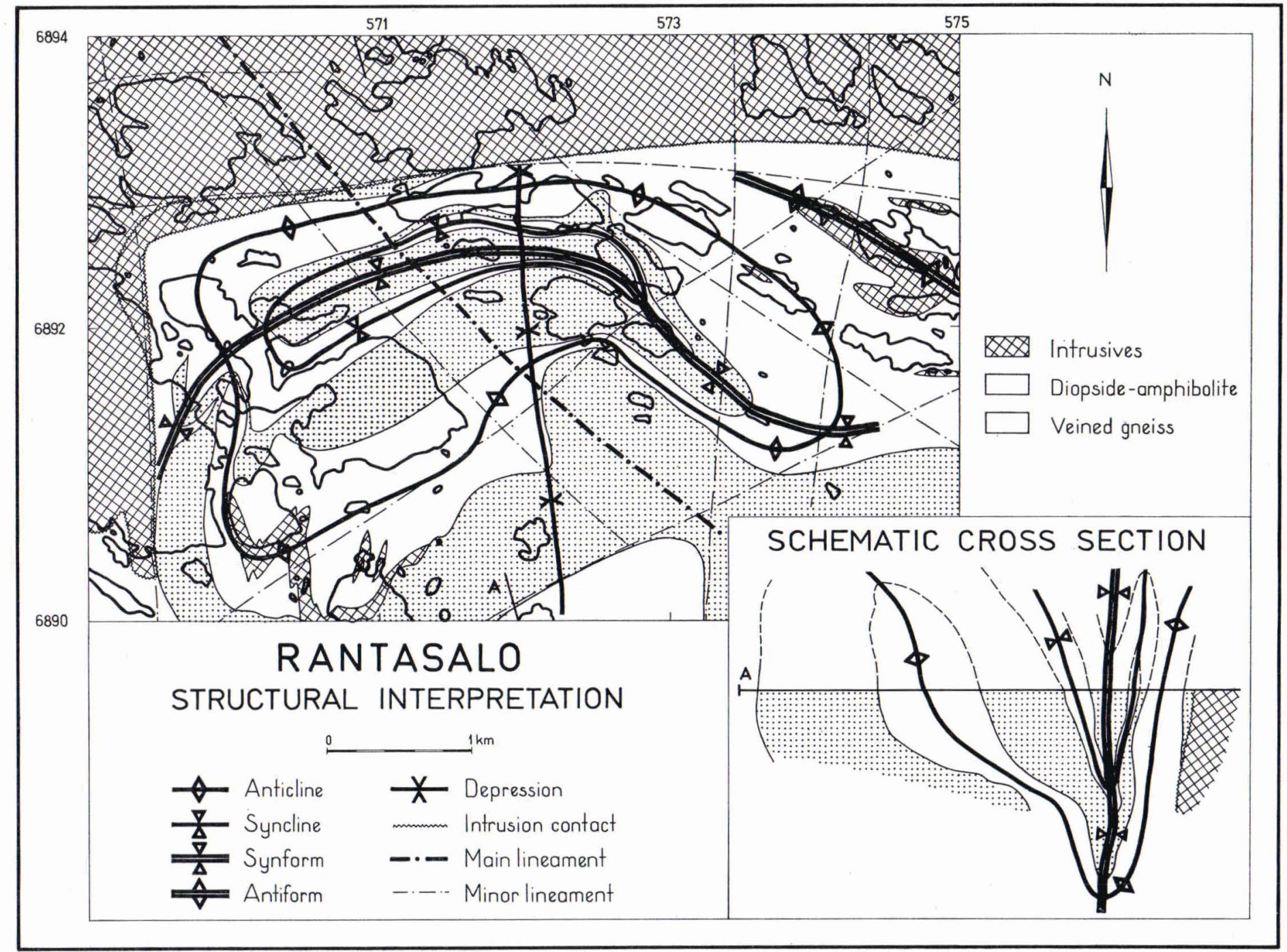

FIG. 47. 
S e u r a a a ri s y form. A metamorphosed diorite is exposed in the core of this synform which has been described by B. Saltikoff (1965) as the cummingtonite-gneiss of Lääväsaari. The diopside-amphibolite of this structure exhibits signs of extremely strong deformation and has the appearance of »stengelgneiss» with the lineation formed by rodding. The diopside-amphibolite of the diagram area has axial plane schistosity which is an uncommon structural feature in the diopside-amphibolite of the Haukivesi area. The axis of the Seurasaari synform is rather steep and plunges 070/60 in the eastern part (Diagram 75) and 049/55 in the western part (Diagram 77).

In the environment of Rantasalmi, the tectonic style changes abruptly south of the diopsideamphibolite belt. The well-preserved metaturbidites of Rantasalmi exhibit regular deformation patterns. Top and bottom determinations have led to the conclusion that the metaturbidites around Rantasalmi are folded in a tight isoclinal fold, the $\mathrm{R}$ a n t a s l mi s y n c lin e. The average dip of the axial plane of this syncline is about $359 / 74$ in diagram area 24 and about $008 / 80$ in diagram areas 48 and 49 . Due to the effect of a N-S striking cross fold zone which transects the Haukivesi area from Äimisvesi to Putkilahti, the strike of the metaturbidites suddenly changes W of Rantasalmi to a N-S direction. The deepest layers of the metaturbidite complex rise up in anticlinal cross fold, the Putkilahti a nticline. In this fold, which plunges an average of $45^{\circ}$ towards $\mathrm{S}$, the basement of the metaturbidite series extends southwards as far as the northern shore of Lake Suuri-Rauvavesi. The hinge of the Putkilahti anticline has been intruded by an association of igneous rocks ranging from intermediary to ultrabasic composition.

The intensity of the deformation seems to increase as the Rantasalmi metaturbidites W of Putkilahti grade into granitized cordierite-bearing gneisses. In Parkumäki, an uncountinuous 0 $-1000 \mathrm{~m}$ thick layer of diopside-amphibolite branches off from the main amphibolite belt and extends with increasing thickness towards Savonlinna. This amphibolite layer is primarily connected with a polymictic conglomerate horizon. The former belongs to the eugeosynclinal series and the latter is the basal transgression conglomerate of the miogeosynclinaly sequence. It is assumed that the basal part of the synorogenic series together with a thin layer of its basement was sliced off in the southern Haukivesi area and thrust over the Savonlinna cordierite-gneisses along the Savonlinnan thrust $z$ on e. The thrusting towards the south did not proceed along a single plane, but in a thrust and fold zone a few kilometres in thickness. The $\mathrm{K}$ a $11 \mathrm{is}$ lahti imbrication zone offers a good example of this mechanism.

The thrust zone of Savonlinna was studied in some detail in the environment of the town of Savonlinna. Results of the structural analysis of this sub-area are presented in Figs. 48 and 49. The direction of the tectonic transport, tectonic axis a, is marked in the Savonlinna area by a well-developed NNE plunging lineation. The mechanism of the thrusting is most obvious in the conglomerates, where in some places pebbles of a few cms in diameter are drawn out into $11 / 2 \mathrm{~m}$ long rods in the direction of lineation. The direction of the fold axis is essentially different and in some places the lineation is affected by folding around the b-axis (Diagram 86). In the western part of the area (Diagrams $84,85)$, the fold axis plunges towards NE and in the eastern part towards NW (Diagrams 83, 86, 87 and 91). In the explanation to Fig. 49 the thrust plane is placed under the conglomerate, because the habit of the latter indicates the thrusting most clearly. However, the thrusting has affected a broad zone in and around the amphibolite. In the first phase of deformation, recumbent isoclinal folding together with thrusting took place. In the second phase, a depression was formed parallel to the direction of the lineation. In the third phase, minor ENE-WSW striking synforms and antiforms were superposed on the older structures. The shapes of these 


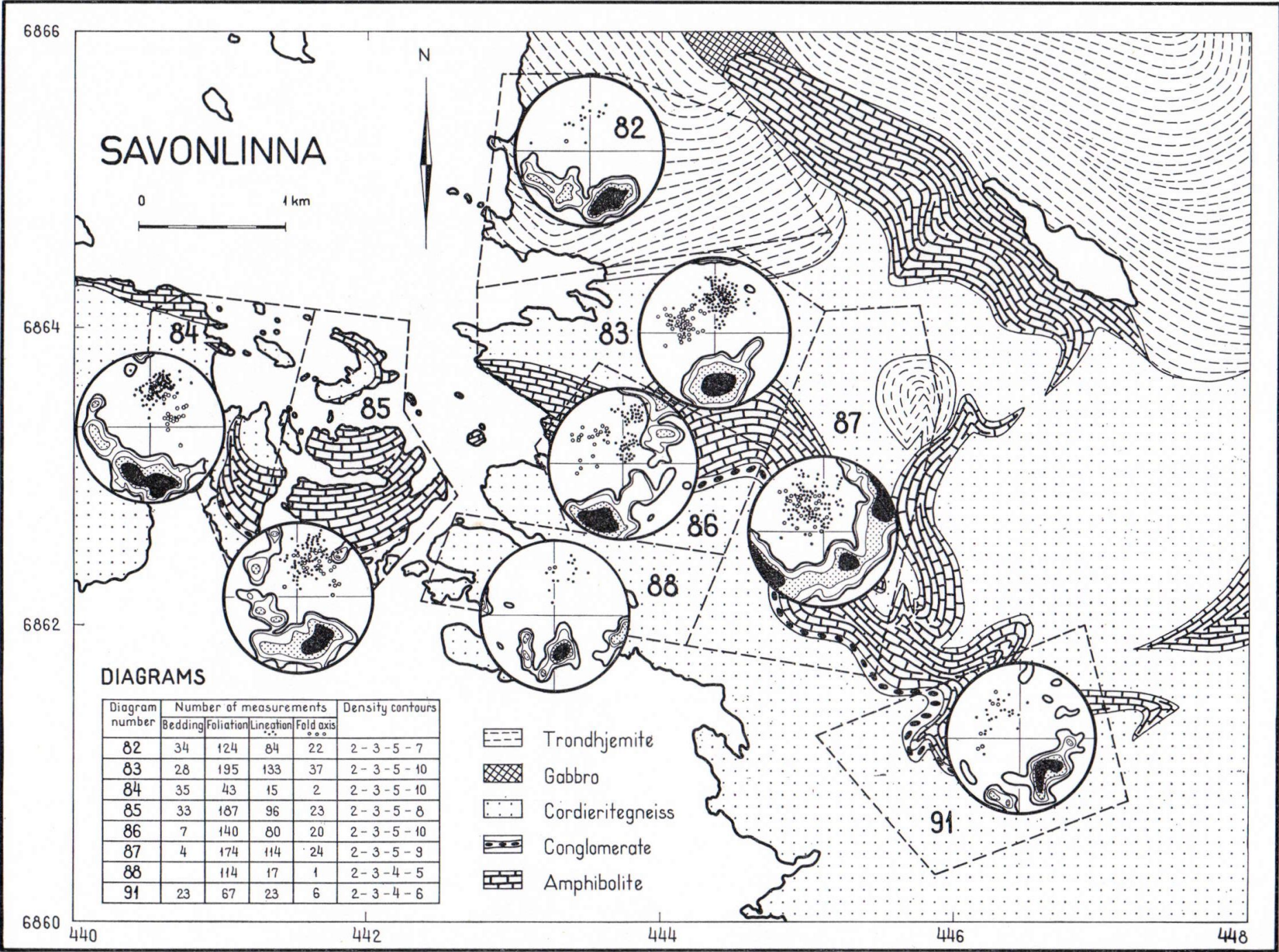

FIG. 48 , 


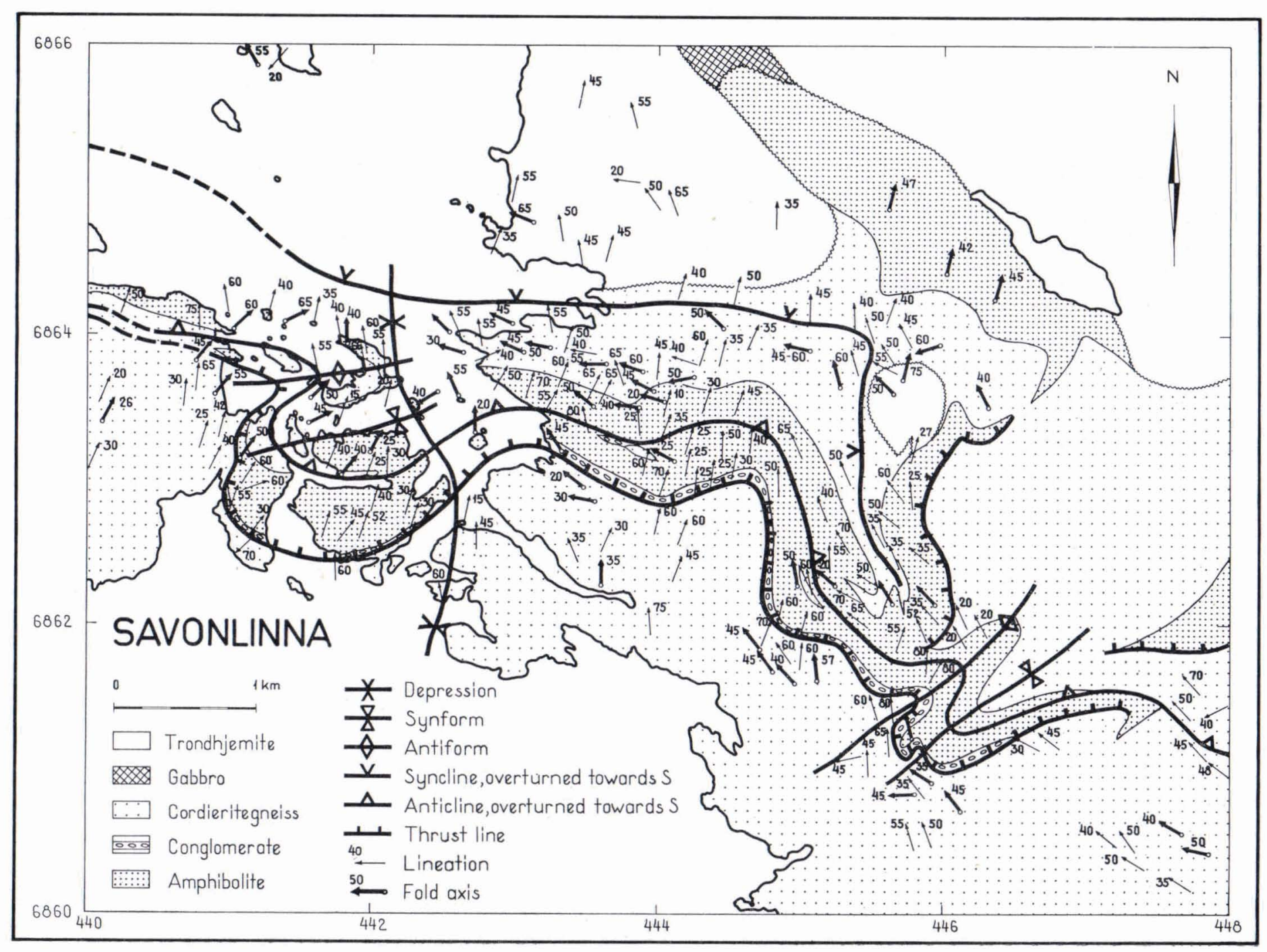




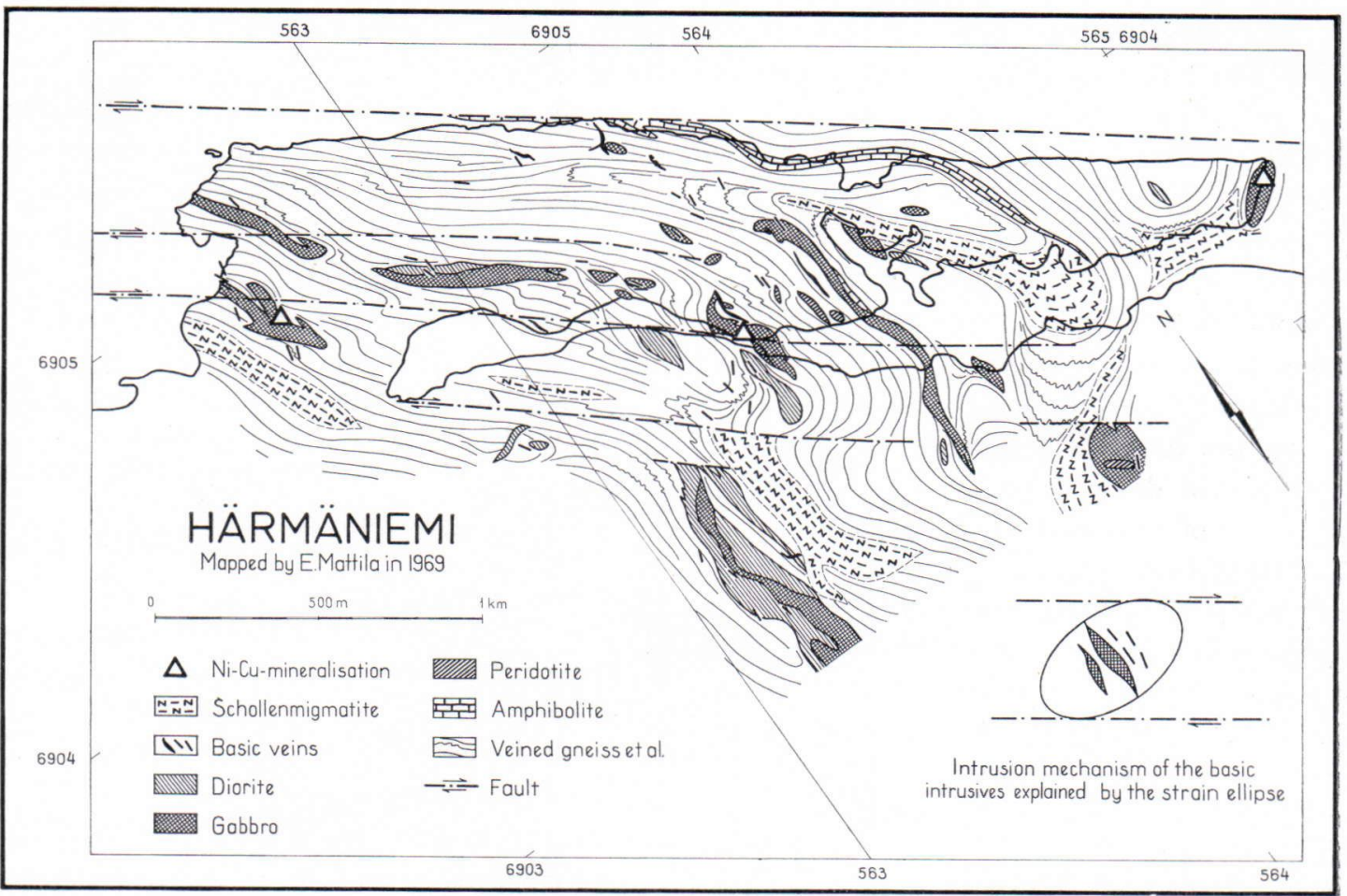

FIG. 50

third phase folds govern the morphology around the town of Savonlinna.

Vertical folds

There are three large vertical folds connected with the Haukivesi fault zone in the Haukivesi area. These folds play an important role in the overall structural interpretation and are therefore described separately. Since they deform earlier structures, e.g. the synforms and antiforms, they must be regarded as belonging to a folding phase which lasted longer as the synforms and antiforms producing phase. The vertical folds are important structures in the tectonics of intrusions, because during their formation openings and weakness zones provide suitable channels for intrusions.

The structures of the Harjuranta and Voinsalmi synforms as well as the KostonsalmiTeemassaari antiform were refolded in a large righthand fold, the Härmäniemi vertical fold.
The northern part of this structure has been mapped in detail by E. Mattila and Fig. 50 clearly depicts this flexural fold.

The vertical fold of the central Haukivesi area bends the Rantasalmi synform and the Linnansaari brachyantiform into a large left hand fold. The formation of this vertical fold was accompanied by the intrusion of the Vuorisaari pluton.

The vertical fold of the southern Haukivesi area has had the greatest effect on the older structures by forcing the earlier linear structures into a right hand fold (Map 3). This fold probably opened up the space for the intrusion of the Joutsenmäki-Tolvanniemi massif.

\section{Synorogenic fracturing}

Even under the high-pressure and high-temperature conditions prevailing in the Haukivesi area, deformation was only partly plastic. Evidence of fracturing during deformation is visible in many exposures. The most obvious examples. 
are the schollenmigmatites and boudinated competent layers, although considerably larger fractures affecting more sizeable geological formations certainly exist, as is reflected in the arrangement of the outcrops and the morphology (Map 6). It is a difficult task to study the nature of these structural elements since they are almost without exception unexposed. Many of the fractures must be regarded as very old, having developed, according to structural analysis, during the orogenic processes connected with their plastic deformation. One cause for the formation of such fractures could be the sudden increase of stress in the acting stress field. Generally speaking, the material passed the field of plastic deformation before rupturing and finally the stress relaxed by failure of the material. G. P. L. Walker (1969) has pointed out that even viscous magma can break when stresses are applied rapidly enough. Fractures formed in this way must be distinquished from those developed by brittle fracturing. The former are usually synorogenic and in this paper are termed synorogenic fractures.

The synorogenic fracture system of the Haukivesi area consists of three different fracture sets. The predominating set, which is called the $\mathrm{H}$ a u kivesi fault zone, has a NW-SE strike. The other two sets have E-W and N-S strikes respectively. The Haukivesi fault zone belongs to a long and narrow lineament swarm which traverses Finland from Parikkala towards Ylivieska and is well-known for its $\mathrm{Ni}-\mathrm{Cu}$ bearing basic to ultra-basic intrusions. Since its strike is close to the direction of the glacial movement, a fact which has accentuated the NW-SE trending lineaments, the Haukivesi zone can well be located on the basis of its morphology. Its two dominating lineaments are called the $\mathrm{Haukivesi} f a u t \mathrm{ine}$ and

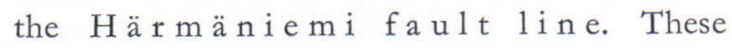
faults are the manifestations of a broader shear zone which was active over a long period. In this shear zone, large vertical dragfolds were formed during the latest deformation phase and frac- turing occured parallel to the axial plane of the vertical folds. The complicated folding, shearing and faulting mechanism along the Haukivesi fault zone was the primary cause of the emplacement of the pyroxene-bearing intrusions and the $\mathrm{Ni}-\mathrm{Cu}$ mineralizations encountered in the area.

\section{TECTONIC OF INTRUSIONS}

\section{A. Early tectonic phase}

The oldest intrusive rock in the investigation area seems to be a foliated homogeneous trondhjemite, which is found a typical syntectonic intrusion. Since more' or less conform trondhjemite sheets are folded together with amphibolite into domes, antiforms and synforms, it must be assumed that trondhjemite intruded during an early tectonic phase in subhorizontal sheets, perhaps in connection with thrusting and recumbent folding. The thickness of the trondhjemite sheets varies from a few centimetres to some hundreds of metres. The lit-par-lit injection by trondhjemite parallel to the bedding and foliation of diopside-amphibolite is perhaps the most characteristic phenomenon of the intrusion.

\section{B. Main tectonic phase}

The intrusive rocks of the main tectonic phase are regarded as the derivates of a dry mangeritic magma ranging in composition from peridotitic to quartzdioritic. The mangeritic magma is contaminated at its contacts by water-bearing supracrustal rocks and changes in composition into a heterogeneous hybridic trondhjemite.

The intrusions of the hypersthene-bearing igneous rocks of the main tectonic phase are in clear relation to the vertical folds and the Haukivesi fault zone. A large-scale drag along this zone produced strike-slip faults and folding. The emplacement of the mangeritic magma took place in complete harmony with these regional tectonic events. The drag along the fracture zone opened up spaces which were readily filled with igneous 
material. During their formation, plunging or vertical flexural folds literally sucked up magma through the open spaces along their hinge zones. As the antiforms and synforms were formed, the magma spread out, using weakness zones produced by the folding, and were emplaced in large conform sheets or in pipe-like formations in suitable parts of the fold structures. The magmatic differentiation was disturbed under these syntectonic conditions, which explains the strong and irregular variation in the petrographic composition of the hypersthene-bearing intrusive rocks. The tectonic movements continued to act after the consolidation of the magma. As the deformation went on, smaller diorite, gabbro and peridotite bodies broke up and their fragments were spread out by tectonic transport. The tectonic forces frequently caused foliation in the basic intrusive rocks. Diorites and quartz-diorites are usually well-foliated near their contacts but unfoliated futther away. On the the other hand, peridotites and gabbros were resistant to the mecharism producing the foliation.

\section{The basic igneous rocks of Härmäniemi}

There are numerous small diorite, gabbro and peridotite bodies in connection with the Härmäniemi vertical fold. Owing to the occurrence of two small $\mathrm{Ni}-\mathrm{Cu}$ mineralizations, the geology of this sub-area was studied in detail. Fig. 50 explains the mechanism of the intrusions. The right-hand force couple, which formed the Härmäniemi vertical fold, opened up dilation fractures which mainly strike $\mathrm{N}-\mathrm{S}$ and which run parallel to the foliation. These spaces were intruded by a comagmatic series of basic igneous rocks. As the deformation continued, the relatively thin sills of igneous rocks became broken and brecciated. In the course of the folding, these fragments became rolled parallel to the fold axis and it is to be expected that the basic bodies extend in pipe-like fashion to a depth parallel to the almost vertical fold axis.

\section{The Joutsenmäki-Tolvaniemi massif}

The Joutsenmäki-Tolvaniemi massif is the largest single intrusive body in the area, being $19 \mathrm{~km}$ long and 4 to $6 \mathrm{~km}$ broad. It is a heterogeneous massif of diorite and gabbro surrounded by a conspicuous shell of coarse porphyric granodiorite. Since the internal structure of this massif is being studied by O. J. Parkkinen, the present authors only investigated the tectonic relations in the surrounding supracrustal rocks in order to draw conclusions concerning the emplacement of the intrusive body. The massif seems to be an autochtonous plutonic body which intruded during the formation of the vertical fold of the southern Haukivesi area along the Haukivesi fault zone. The western part of the massif is probably bordered by a curved vertical plane belonging to the southern part of the vertical fold. The eastern part of the massif seems to be underlaid by the surrounding rocks, since the linear structures plunge, here, under the pluton (Map 3). A hypothetic picture of a plutonic body which has risen in a vertical pipe and spread out eastwards in a bowl-like structure grows out of these observations. The circular arrangement of the outcrops in the western part of the intrusive body (Map 6) may represent the horizontal section of a vertical pipe which acted as the channel of intrusion.

\section{Late tectonic phase}

The late tectonic phase is represented by fairly uniform coarse porphyric hypersthene-bearing granite and granodiorite as well as occasionally by quartzdiorite. There are three main occurrences of these rocks in the Haukivesi area: the axial zone of the Harjuranta synform, the Vuorisaari pluton and the margins of the Joutsenmäki-Tolvanniemi massif.

The coarse porphyric granodiorite of the $\mathrm{Vu}$ oris a a r i-plut on has been described by V. Hackman (1933, p. 126-127) as the youngest intrusive rock of the Haukivesi area. 


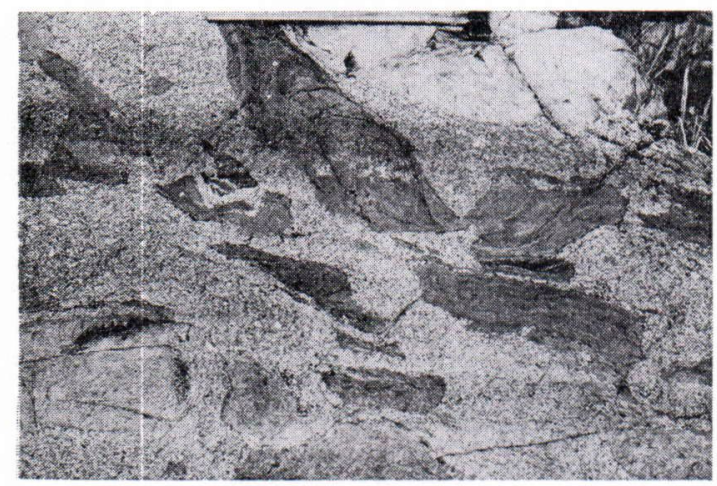

FIG. 51. Coarse porphyric granodiorite brecciating diopside amphibolite and trondhjemite. Tiheissaari, Rantasalmi.

This observation was confirmed in the present study. The Vuorisaari pluton contains inclusions of gabbro, diorite, quartzdiorite, trondhjemite, schollenmigmatite and veined gneiss (Fig. 51). Thus, it is decidedly younger than the intrusive rocks of the main tectonic phase and the regional migmatization of the veined gneisses. Its contacts are on the whole conform. The only discordant contact observed was in Torasalo where the pluton sends an apophyse towards the NW. In the same direction, two small satellites of the Vuorisaari pluton occur in Voinsalmi and Teemassaari. The intrusion of the coarse porphyric granodiorite took place under synkinematic conditions during the formation of the vertical fold of the central Haukivesi area. Near the contacts, the porphyric feldspars of the pluton are oriented parallel to the direction of the general strike, but in the central parts, the rock is completely unoriented. The large vertical fold opened up an arch-shaped space which originally attracted the intrusion of a gabbro and subsequently the intrusion of the granodioritic material, which later migmatized and partly digested the older gabbro. The process of intrusion in the contact zones was probably a slow process controlled by diffusion. The growth of large porphyric feldspars in the surrounding host rocks (Fig. 29) developed as a result of soaking by the granodioritic material.
The conditions during the formation of the coarse porphyric shell around the JoutsenmäkiTolvanniemi massif must have been somewhat similar. The granodiorite used the same intrusion channel as the diorite and gabbro and penetrated the tectonically still active contact zone of the plutonic body after the consolidation of the basic material. Parallel orientation of the porphyric feldspars clearly indicates the synkinematic nature of the rocks.

Special attention should be paid to one rather significant feature of the coarse porphyric texture of the late tectonic intrusive rocks. As shown above, the intrusion of these rocks took place under synkinematic conditions and contact phenomena indicate the importance of diffusion processes in connection with the magma. Therefore, it can be assumed that the penetrative tectonic movement in the intruded material produced high strain energy which under the high rates of diffusion favoured the nucleation and growth of porphyric feldspars.

\section{Basic dykes}

Fine-grained basic dykes from a few $\mathrm{cm}$ to $2 \mathrm{~m}$ in thickness cut the intrusive rocks of the early, main and late tectonic phase in the Haukivesi area. These dykes sometimes cut pegmatites, but sometimes they are themselves cut by pegmatites. A large majority of the basic dykes have a $\mathrm{N}-\mathrm{S}$ and NNW-SSE strike and a vertical or almost vertical dip. These are indications that during the formation of the dykes a more or less homogeneous stress field prevailed in the Haukivesi area.

\section{E. Granitic veins}

The youngest intrusive rocks of the investigation area, granite, pegmatite and aplite, either cut the intrusive structures in discordant or conform veins. Under these circumstances, the granitic material ceased to effect the tectonics of the area. However, distinct maxima in the orientation of the granitic veins indicate the existence 


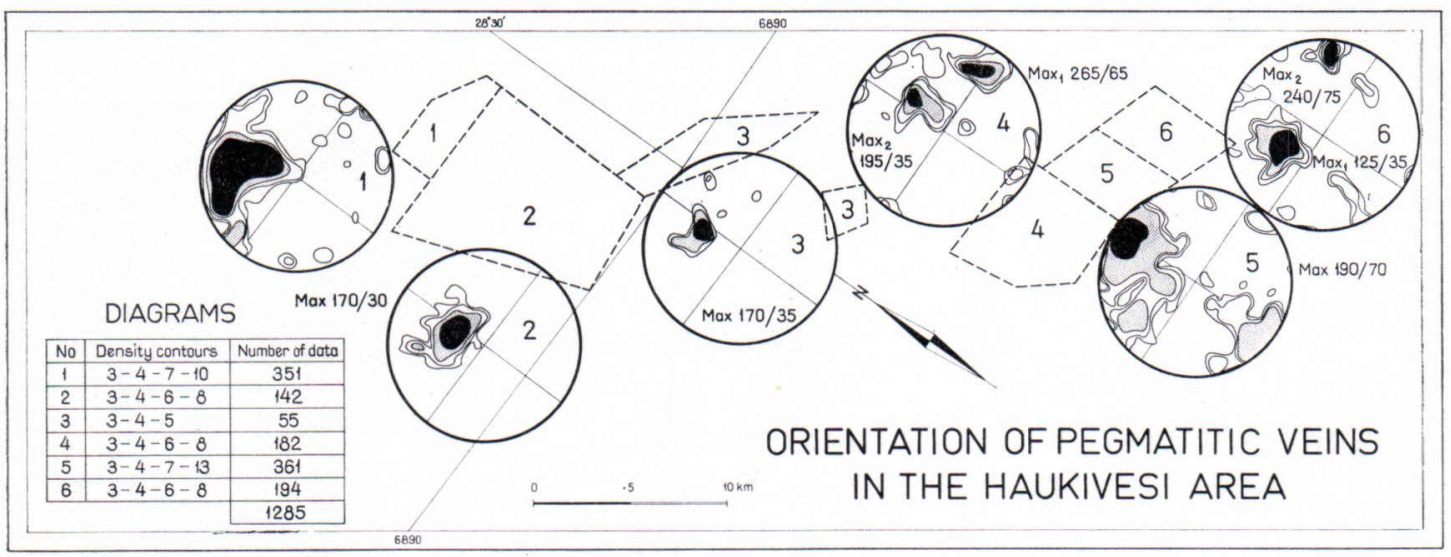

FIG. 52

of a stress field during their formation. The orientation of the granitic veins was studied statistically and 1285 determinations were plotted in six diagrams on the Schmidt net (Fig. 52). There are clear maxima in the northern and central Haukivesi area showing that by far the greatest part of the veins dips with a low to steep angle towards S-SE. In the area of the Joutsenmäki-Tolvanniemi pluton, conditions are more complicated and additional maxima occur.

\section{KINEMATIC ANALYSIS}

The main directions of deformation, which roughly correspond with the average strike of the steeply dipping planar structures and which can be called the main axis of strain, have frequently changed in the course of deformation. A superficial review of the tectonic and stratigraphic material could lead to the impression that the various directions of deformation acted simultaneously producing a complicated mosaic of interference patterns. However, the geometric analysis revealed that it is possible to deduce a time sequence of tectonic events (Table 10), although, due to the temporary overlapping of various deformations, temporal differences are often obscured. In Table 10, the intensity of each respective geologic event in time is symbolized by a black line of varying thickness on the left hand side of each column.

\section{A. Pre-orogenic stage}

The first detectable tectonic event in the investigation area is the fracturing. The Haukivesi fracture zone made its appearance during an eugeosynclinal stage opening up steep and deep-seated fractures in the crust along which basaltic lava rose and flowed out to the bottom of the sea (Fig. 53A). From this time on the Haukivesi fracture zone has remained active.

\section{B. First deformation phase}

Shortly after the volcanic activity, sedimentation in the eugeosyncline north of the Haukivesi fracture zone ceased and folding of the eugeosyncline sediments started. At the same time, subsidence produced a flysch geosyncline south of the Haukivesi fracture zone in which large amounts of turbidites rapidly accumulated (Fig. 53B). As the folding proceeded from the north towards the south the synorogenic series of the turbidites was caught by folding. Conclusions about this folding phase are naturally hypothetical, since subsequent deformations and intrusions have obscured the earlier structures. 
TABle. 10.

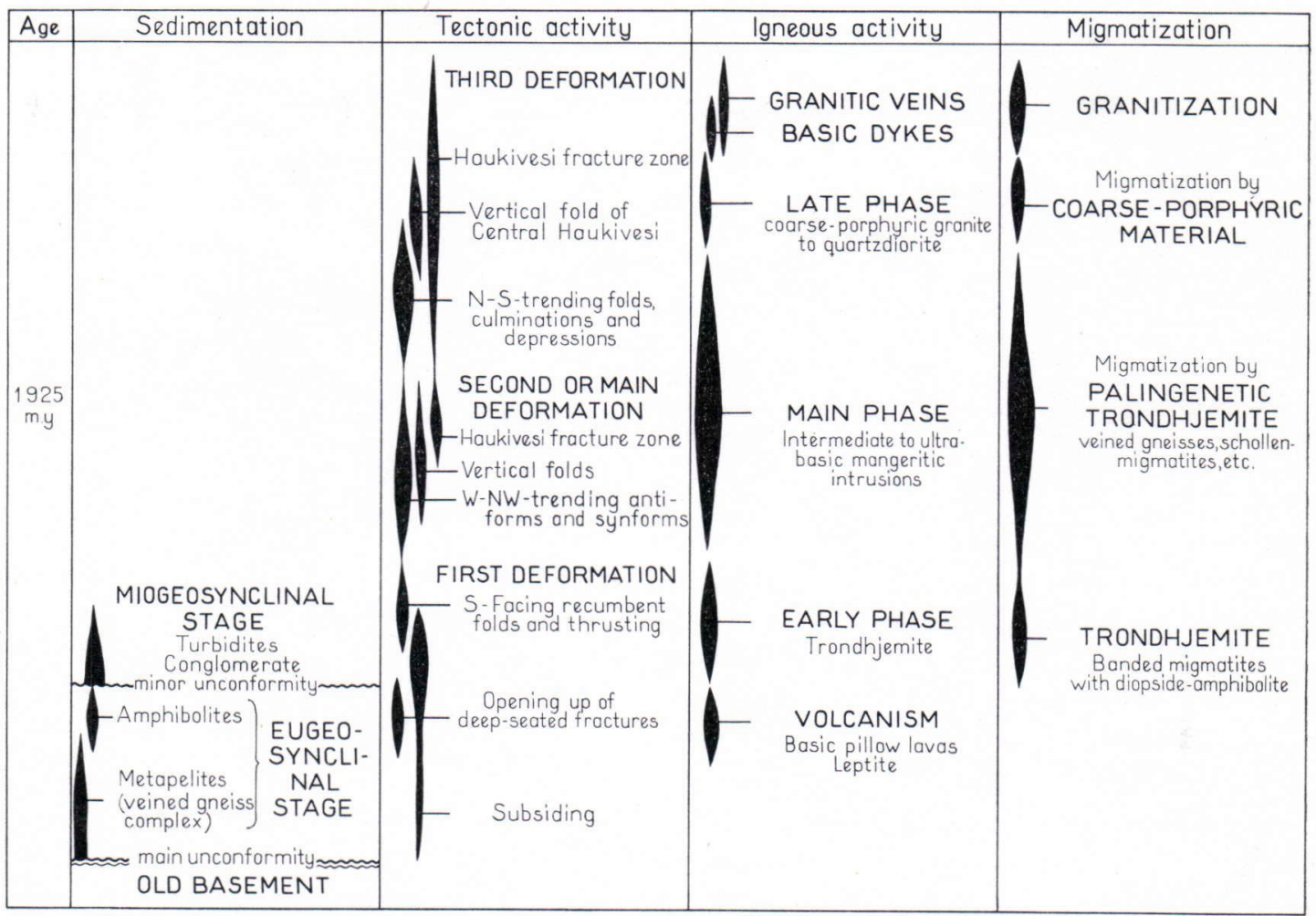

However, it can be assumed that this deformation phase produced recumbent folds with an E-W strike facing in a southerly direction. The refolded recumbent folds of the Rantasalo synform, the Kallislahti imbrication zone and the Savonlinna thrust zone are interpreted as relics of the folding phase.

The tectonic style of the first deformation phase was thus dominated by folds facing $S$ which were connected with the thrusting (Fig. 53C). During this phase, large conform sheets of trondhjemite intruded the Haukivesi region.

\section{Second or main deformation phase}

The dominating W-NW striking fold sets of the area were formed during the maximum intensity of tectonic activity, ie. during the second or main deformation phase (Fig. 53D).
Not only tectonics but also igneous activity reached their peak during this period. In the vicinity of the Haukivesi fracture zone, the hypersthene-bearing intrusions of the main magmatic phase spread out and took part in the folding as synkinematic intrusions.

The W-NW striking synforms and antiforms were the first to be formed during this deformation phase. They face south and their axial planes dip $\mathrm{N}-\mathrm{NE}$ at angles of $60-90^{\circ}$. Subsequently and partly synchronously two large vertical right hand folds, the Härmäniemi and the Southern Haukivesi vertical fold were formed by the drag which developed in a shear zone along the central axis of the Haukivesi area. Fracturing and intrusion of mangeritic magma accompanied this tectonic event.

In the southernmost part of the area SWtrending fold sets predominate. Here seems to be 


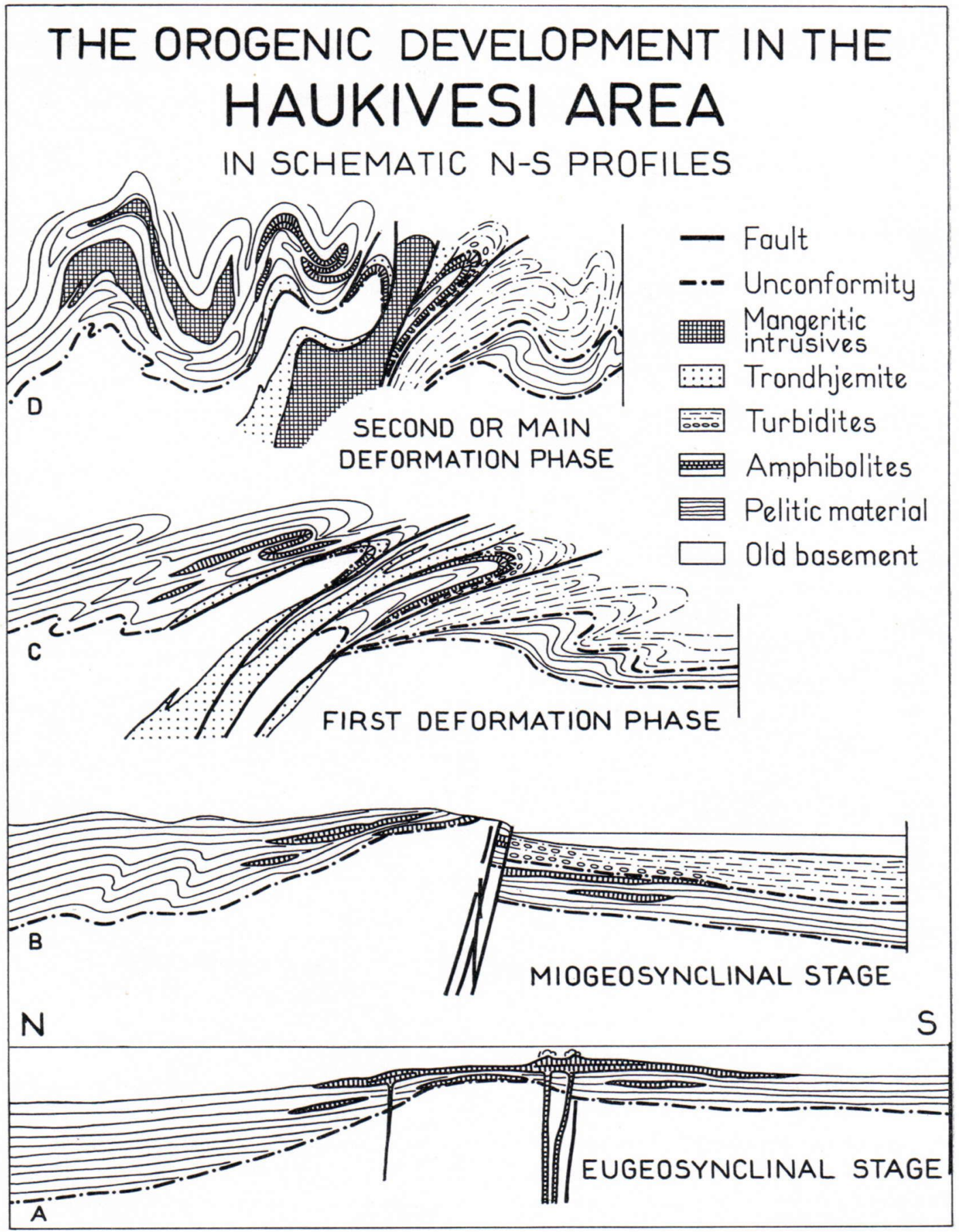

FIG. 53. 
a rather abrupt change of strike just south of the conglomerate horizon. However, on the basis of the relatively small area it is now impossible to make any conclusions about this fold direction.

\section{Third deformation phase}

The folds of the main deformation phase are deformed in fold zones striking N-S (Fig. 55). These $\mathrm{N}-\mathrm{S}$ striking structures are superposed folds, which deformed the folds of the main deformation phase into culminations and depressions.

The most convincing basis for this interpretation is given by the contoured map of linear structures (Map 3). Some intrusions, eg. the basic and ultrabasic rocks of Putkilahti and the Vuorisaari pluton are clearly associated with this deformation phase.

The central axis of the Haukivesi area was the longest to remain a tectonically unstable zone. Here was formed the youngest fold structure of the area, the vertical fold of the Central Haukivesi, which opened up the space for the intrusion of the Vuorisaari pluton. This deformation phase produced its own fracture system, which was partly superposed on the previous one.

\section{DYNAMIC ANALYSIS}

The overlapping kinematic processes indicate that the Haukivesi area has been continuously subjected to influences of a complex stress field ever since the early geosynclinal stage. The orientation and intensity of this stress field have changed with the course of time. At first, during the formation of the main geosynclinal stage, it built up rather slowly. During the formation of the turbidite stage steadily increasing forces acted to produce the structure of the first deformation phase. The intensity of the acting stress field reached its peak during the second or main deformation phase. After the third deformation phase the stress field started to relax. The relaxation was as slow as the build up.
In an area of such complex deformation patterns, only hypothetical conclusions can be drawn concerning the extinct stresses. However, some propositions can be put forward in order to make comparisons with the tectonics of other areas possible.

\section{A. Pre-orogenic stage}

On the basis of such a relatively small area, it is impossible to determine the nature of the stress field which caused the subsidence during the eugeosynclinal stage and later during the miogeosynclinal stage.

The existence of a geanticline was postulated between the eugeosynclinal basin in the north and the miogeosyncline in the south. It could be thought that the margin of this geanticline, which perhaps developed like horst, became fractured under tension and tension fractures functioned as channels for the intrusion of the basaltic magma.

\section{B. First deformation phase}

During the first deformation phase, the greatest normal stress $\left(\sigma_{1}\right)$ probably acted in a subhorizontal position in a $\mathrm{N}-\mathrm{S}$ direction. Since the overburden at this stage was relatively thin, the smallest normal stress $\left(\sigma_{3}\right)$ must have acted perpendicularly to the surface of the crust. Because of the great difference between $\sigma_{1}$ and $\sigma_{3}$, low angle thrust planes and flat to recumbent folds were formed in the partly still unconsolidated sediments.

\section{Second or main deformation phase}

In this phase the orientation of the stress field (Fig. 54) did not change. The greatest normal stress $\left(\sigma_{1}\right)$ continued to act as a compression in $\mathrm{N}-\mathrm{S}$ direction. However, the principal stress acting in the vertical direction increased considerably to become the intermediate normal stress $\left(\sigma_{2}\right)$. The least normal stress $\left(\sigma_{3}\right)$ resulted in a moderate compression in $\mathrm{E}-\mathrm{W}$ direction. 


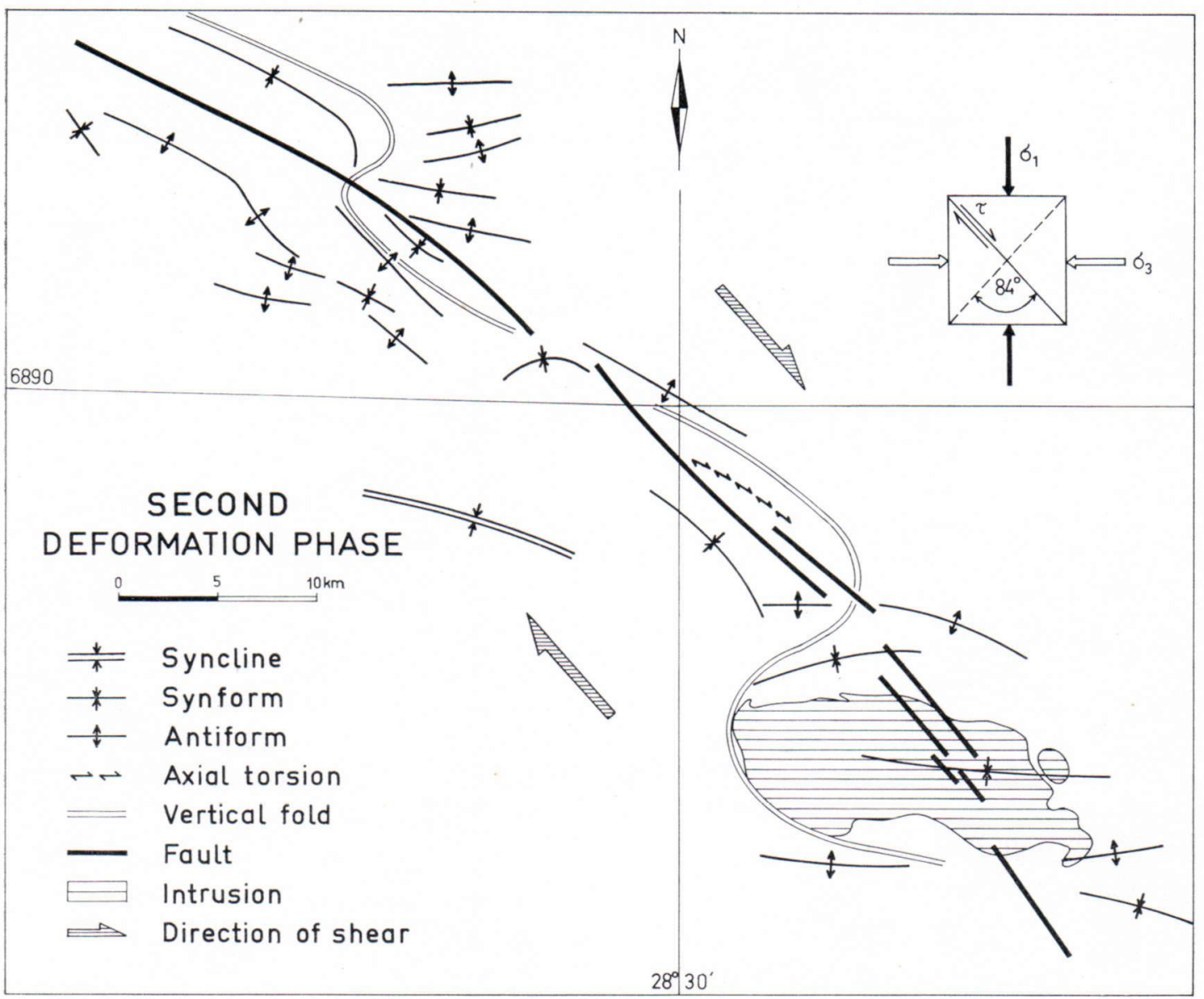

FIG. 54.

Because of the great difference between $\sigma_{1}$ and $\sigma_{3}$ a rather strong shear stress $\tau= \pm \frac{\sigma_{1}-\sigma_{3}}{2}$ developed in N $42 \mathrm{~W}$ direction. This stress field generated $\mathrm{E}-\mathrm{W}$-striking folds in en echelon manner, which were immediately effected and rotated by a right hand shear towards NW-SE. The shear stress was partly relaxed by vertical folding, partly by transcurrent faulting. The later one seems to be less significant since displacement along the faults is small.

The subparallel orientation of the basic dykes indicates that a uniform stress acted during their intrusion. This stress field can be regarded as the action of the forementioned $\tau$ : in NW-SE direction a right-hand lateral force couple caused the formation of $\mathrm{N}$-S-strending fracture openings intruded by the basic material.

\section{Third deformation phase}

Also in this phase orientation of the stress field (Fig. 55) remained constant whereas the intensity of forces changed. The main normal stress $\left(\sigma_{1}\right)$ acted at this time in $\mathrm{E}-\mathrm{W}$ direction and the least normal stress $\left(\sigma_{3}\right)$ in $\mathrm{N}-\mathrm{S}$ direction. A rather strong shear $(\tau)$ developed in N $53 \mathrm{~W}$ direction. 


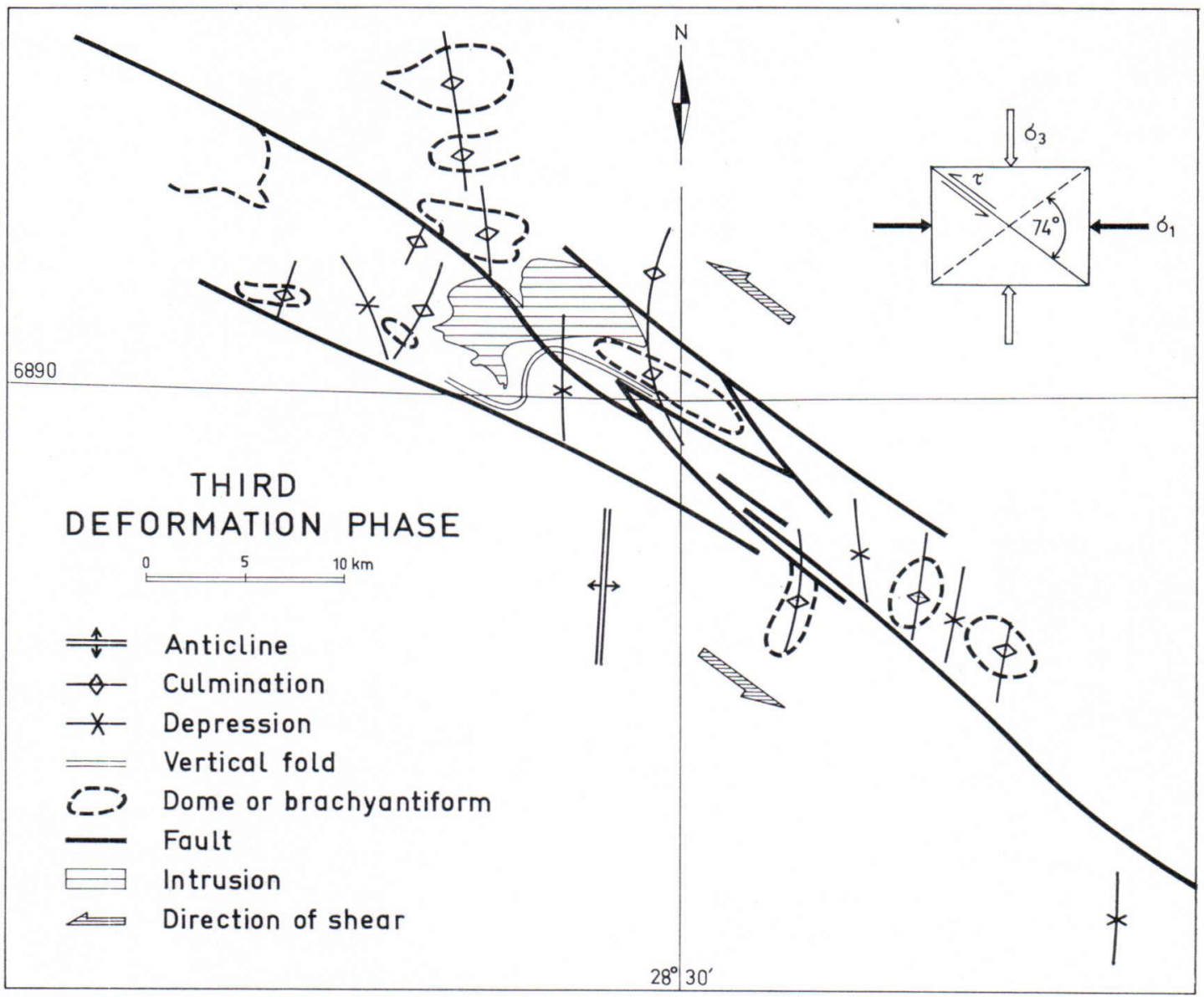

FIG. 55.

This stress field produced $\mathrm{N}$-W-striking folds, culminations and depressions, in en echelon manner. The superposition of these structures on the folds of the second deformation phase lead to the formation of domes and brachyantiforms which are characteristic for the Haukivesi area. The shear $(\tau)$ relaxed in this phase mainly by faulting and the new fracture system of left hand transcurrent faults was superimposed on the faults of the second deformation phase.

The W-SW striking granitic veins of the Haukivesi area are probably associated with the third deformation phase.

\section{ABSOLUTE AGE DETERMINATIONS}

O. Kouvo supplied valuable information about the absolute age of the igneous rocks of the Haukivesi area by the isotopical dating of the zirkons from two specimens of the hypersthene bearing mangeritic suite. Both specimens were taken from Voinsalmi, Rantasalmi. Specimen A 382-GSF $70(x=6896.70, y=561.95)$ is a coarse-porphyric hypersthene bearing granite and specimen A 383-GSF $70(x=6894.85$, $y=563.55)$ is hypersthene bearing quartzdiorite. Analytical data, ages and the concordia diagram 
TABLE 11

Analytical data (zircon)

\begin{tabular}{|c|c|c|c|c|c|c|c|}
\hline \multirow{2}{*}{$\begin{array}{l}\text { Sample } \\
\text { No. }\end{array}$} & \multirow[b]{2}{*}{ U, p.p.m. } & \multirow[b]{2}{*}{ Th, p.p.m. } & \multirow{2}{*}{$\begin{array}{l}\text { Radiogenic } \\
{ }^{206} \mathrm{~Pb} \text {, p.p.m. }\end{array}$} & \multicolumn{4}{|c|}{ Isotopic abundance relative to ${ }^{206} \mathrm{~Pb}$} \\
\hline & & & & 204 & 206 & 207 & 208 \\
\hline $\begin{array}{ll}\text { A382-GSF } & 70 \\
\text { A383-GSF } & 70\end{array}$ & $\begin{array}{l}359 \\
964\end{array}$ & $\begin{array}{l}\ldots \ldots \\
\ldots \ldots\end{array}$ & $\begin{array}{r}99.97 \\
258.67\end{array}$ & 0.0095 & $\begin{array}{l}100 \\
100\end{array}$ & $\begin{array}{l}11.49 \\
11.60\end{array}$ & $\begin{array}{l}9.10 \\
7.09\end{array}$ \\
\hline
\end{tabular}

TABLE 12

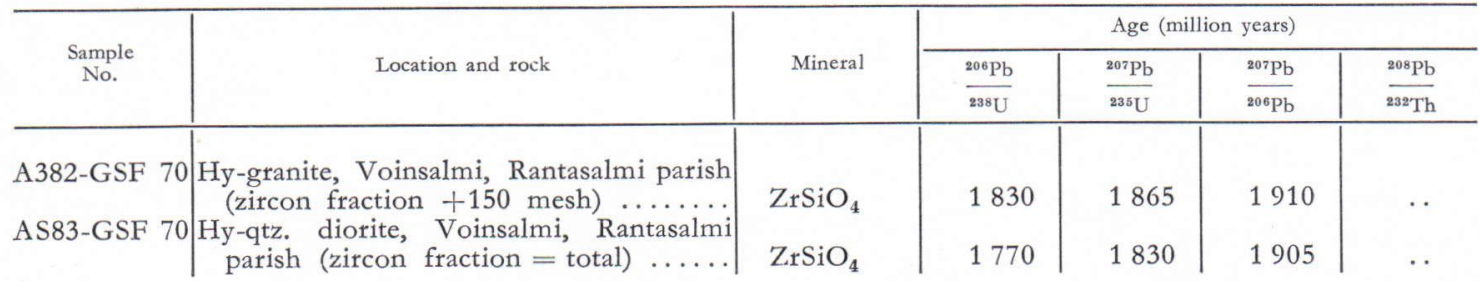

$\mathrm{e}^{\lambda \mathrm{t}}-1$ values if plotted on a concordia-

discordia diagram:

A382 206/238 $=0.3243207 / 235=5.136$

A383 206/238 $=0.3121207 / 235=4.935$

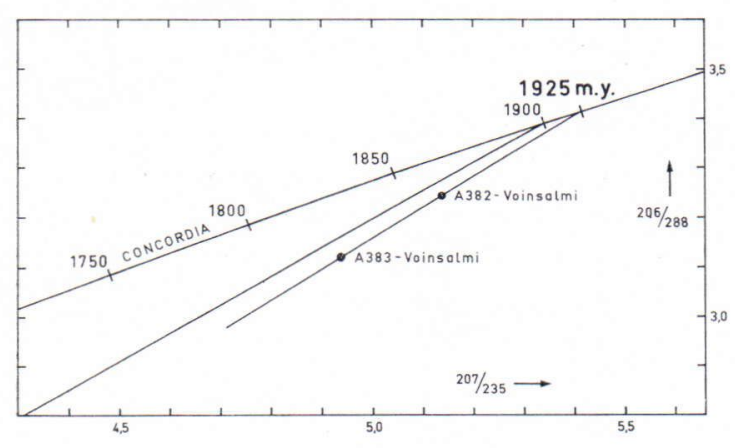

FIG. 56.

according to O. Kouvo are given in tables 11 . and 12. and fig. 56.

Both zirkons give the absolute age of about $1925 \mathrm{~m} . \mathrm{y}$. This is corresponding to the total age of the intrusive rocks of the Svecofennian and Karelian belts which is given by $\mathrm{O}$. Kouvo and G. R. Tilton (1966) as $1915+20$ m.y. and is in good accordance with the structural and petrological analysis of the present study, which describes the mangeritic rocks as typical synoro- genic intrusions. On the contrary, the assumption of W. Wahl (1963) that »the hypersthene rocks are about 100 million years younger than the principal part of the remaining rocks of the Svecofennidian movement» is not verified in the Haukivesi area.

\section{CONCLUSION}

The sedimentation, volcanism, intrusion and deformation history of the Haukivesi area indicate a preexisting geosynclinal system which is part of a far greater orogenic belt. The Rantasalmi metaturbidites are strongly reminiscent of both the Kalevian phyllites of the Karelidic belt and the Tampere schists of the Svecofennids. On the other hand, the characteristic intrusive rocks of the Haukivesi area, trondhjemite and charnockites, testify to a relationship with the Svecofennids.

The NW-SE trending zone of charnockitic hypersthene-rich rocks along the central axis of the Haukivesi area is a zone of metamorphic 
facies formed under high temperature-pressure conditions of the granulite facies. The basic and ultrabasic intrusive rocks outside this zone are clearly different from the rocks of the charnockitic suite. The different petrographic characteristic of the Putkilahti intrusive stock can be explained for example by its occurrence within the rocks of considerably lower metamorphic facies, the Rantasalmi metaturbidites. It can be assumed that the zone of high temperature-pressure conditions is far more extensive and alludes to the zone of hypersthenebearing intrusive rocks which runs across Finland via Ylivieska towards Parikkala. The structural analysis in the present work throws some light on the formation mechanism of this wellknown lineament zone which was formed by strong shear stress active during the main and late deformation phase of the orogeny.

Another significant conclusion of the structural analysis is that the direction of tectonic transport in the Haukivesi area appears to have been towards the south. As is generally known, the tectonic transport in the Karelids was east to northeast.

Acknowledgments - We would like to express our gratitude to the Outokumpu Co. for its generous attitude towards this geological research and for the grant which made the publication of the present paper possible. We are greatly indebted to the Chief Geologist, Dr. Paavo Haapala, for his continued interest in the geology of the
Haukivesi area and for allowing the scientific results of the work to be published. Further, we would like to thank the former director of the Prosp. Dept., Dr. Veikko Vähätalo, who initiated and supported the geological work in the Haukivesi area and the present director Mr. Pauli Isokangas, M. Sc. who has shown understanding and interest for our work.

Out special thanks go to Mr. Erkki Viluksela, M. Sc. who led the Haukivesi operation from 1963 to 1968 with great energy and selflessness. He gave us the opportunity to concentrate on geological research by taking upon himself the burden of administration. He also gave continuous advise in the field and in the office and helped with many lengthy discussions to elucidate our impressions. We are obliged to our co-workers Mr. Jyrki Parkkinen, M. Sc. and Mr. Tapio Karppanen, M. Sc. for their valuable contribution in the field and in the realm of ideas. We also thank those colleagues who augmented our conceptions in the later stages of the work, Mr. Leo Grundström, M. Sc., Mr. Esa Mattila, M. Sc. and Mr. Olof Rosenlund, M. Sc. We are fully aware of the importance of discussions in geological work and, thus, appreciate the fruitful debates with our colleagues, Dr. Aulis Häkli and Dr. Heikki Wennervirta. We are indebted to Olavi Kouvo, Ph. D. for the isotopical dating of two zircons. We recall also thankfully the interesting excursions on the areas of the map sheets Rantasalmi and Sulkava with Mr. Kalevi Korsman, M. Sc. who gave us introduction into the problems of the surrounding areas.

For the translation of the petrological part and the correction of the tectonic and stratigraphic part of the text we are indebted to Mrs. Gillian Häkli. The drawing of maps and figures was carried out by Mrs. Anja Karppanen and we are grateful for her skill and accuracy. Finally, we thank Mrs. Eine Gaál, the wife of the senior author for the typing of the text.

\section{REFERENCES}

Augustrthes, S. S. (1963). Oscillatory zoning of plagioclase-phenocrysts of olivine basalt from Debra-sina, Ethiopia. Chemie der Erde, 23, Heft 1.

Bouma, A. H. (1962). Sedimentology of some flysch deposits. (A graphic approach to facies interpretation). Elsevier Publishing Company.

Elliotr, D. (1965). The quantitative mapping of directional minor structures. Jour. Geol., 73, 865-894.

GAÁL, G. (1964). Precambrian flysch and molasse Tectonics and sedimentation around Rakha Mines and Jaikan in Singhbhum District, Bihar, India. XXII. Int. Geol. Congr. New Delhi, Pt. IV, 331-356
Hackman, V. (1923). Der Pyroxen-Granodiorit von Kakskerta bei Åbo und seine Modifikationen. Bull. Comm. géol. Finlande, 61, 1-23.

- (1933). Kivilajikartan selitys. Suomen Geologinen Yleiskartta. Lehti D2 Savonlinna. Suomen Geologinen Toimikunta, 1-175.

HäKLI, T. A. (1971). Silicate nickel and its application to the exploration of nickel ores. Bull. Geol. Soc. Finland 43, 247-263

Hietanen, A. (1943). Über das Grundgebirge des Kalantigebietes im südwestlichen Finnland. Bull. Comm. géol. Finlande, 130, 1-105. 
- (1947). Archean geology of the Turku district in southwestern Finland. Bull. Geol. Soc. America, 58, 1019-1084.

Holland, T. H. (1893). The petrology of Job Charnock's tombstone. Journ. As. Soc. Bengal, 62, Pt 2.

- (1900). The charnockite series, a group of Archean hypersthenic rocks in Penninsular India. Mem. Geol. Surv. Ind., 28, Pt 2.

Huhma, A. (1959). Explanation to the map of rocks. Sheet 2022 Marttila. Geologinen Tutkimuslaitos.

Kouvo, O. and Tilton, G. R. (1966). Mineral ages from the Finnish Precambrian Jour. Geol., 74, 421-442.

Kuenen, Ph, H. (1959). Turbidity currents a major factor in flysch deposition. Eclogae geol. Helvetiae, 51, 1009-1021.

KURkI, J. (1964). Niemilahden malmilohkareen ja Kuronlahden-Rauhamäen alueen ultraemäksisten ja emäksisten pahkujen petrografiaa. Manuscript in the archives of the Geol. Min. Dept. of the Univ. Helsinki.

Mrkкola, T. (1961). Sediment Groups, Particularly Flysch, of the Precambrian in Finland. Bull. Comm. géol. Finlande, 196, 51-65.

NaнA, K. (1961). Precambrian sedimentation around Ghatsila in East Singhbhum, Eastern India. Proc. Nat. Inst. Sci. India, 27, 361-372.

Parras, K. (1941). Das Gebiet der pyroxenführenden Gesteine im westlichen Uusimaa in Südfinnland. Geol. Rundschau, 32, 484-507.

- (1958). On the charnockites in the light of a highly metamorphic rock complex in southwestern Finland. Bull. Comm. géol. Finlande, 181, 1-13.

Ramsay, J. G. (1960). The deformation of early linear structures in areas of repeated folding. Jour. Geol. 68, $75-93$.

RAuHAмÄкr, E. (1965). Pohjois-Haukiveden alueen intrusiivikivilajeista. M. Sc. thesis, manuscript in the archives of the Geol. Min. Dept. of the Univ. Helsinki.
Rosenquist, I. Th. (1951). Investigations in the crystal chemistry of silicates, III. The relation hematitemicrocline. Norsk Geol. Tidsskr. 29, 65-76.

SAKSELA, M. (1953). Über die tektonische Einteilung der Tiefengesteine. Bull. Comm. géol. Finlande, 159, $19-58$.

- (1961). Aspekte der finnischen geologischen Forschung. Bull. Comm. géol. Finlande, 196, 255-297.

SALLI, I. (1964). The structure and stratigraphy of the Ylivieska-Himanka Schist Area. Bull. Comm. géol. Finlande, 211, 1-67.

SAltikoff, B. (1965). Pohjois-Säämingin (Varparannan) intrusiivimassiivi ja sen ympäristö. M. Sc. thesis, manuscript in the archives of the Geol. Min. Dept. of the Univ. Helsinki.

Srmonen, A. (1960). Pre-quarternary rocks in Finland. Bull. Comm. géol. Finlande, 191, 1-49.

Turner, F. J. \& Verhoogen, J. (1960). Igneous and Metamorphic petrology. McGraw-Hill Book Co.

Wager, L. R., Brown, G. M. and Wadsworth, W. J. (1960). Types of igneous cumulates. Jour. Petr., 1, Pt. 1, 73-85.

WAHL, W. (1963). The hypersthene granites and unakites of Central Finland. Bull. Comm. géol. Finlande, 212, $83-100$.

WALKeR, G. P. L. (1969). The breaking of magma. Geol. Mag. 106, 166-173.

Wegmann, C. E. (1961). Zwei Bautypen prekambrischer Deformations- und Transformationssegmente: Kareliden und Svecofenniden. - Bull. Comm. géol. Finlande, 196, 123-135.

WeISs, L. E. (1959). Geometry of superimposed folding. Geol. Soc. America Bull., 70, 91-106.

Wilkman, W. W. (1925). Om Diabasgångar i Mellersta Finland. Societas Geographica Fenniae, 45.

Manuscript reveived, March 11, 1971. 